\title{
Middle Katian/lowermost Hirnantian ostracods from the Prague Basin (Czech Republic): Diversity responses to climatic changes
}

\author{
Karolína Laublová \& Petr Kraft
}

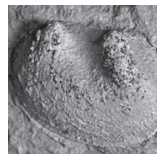

\begin{abstract}
Ostracods are an abundant but long undervalued component of the fossil associations occurring in the Králův Dvůr Formation (Prague Basin; Czech Republic) of the mid Katian to the earliest Hirnantian (Late Ordovician) age. It has been known that they are abundant but it is first evincibly shown that they were also extraordinary diversified. Twenty-eight (plus two dubious) species are described, with only seven (plus the two dubious) having been recorded in the formation before. Ten species are newly established, one established in another area, and ten are kept in open nomenclature. The stratigraphic distribution of the taxa throughout the formation was observed below, inside and above the Perník Bed, the layer of the carbonaceous mudstone interpreted as a response to climatic changes. The taxa from the Perník Bed are described for the first time and those from the interval above this unit have not been studied in detail yet. The pattern of stratigraphic ranges of the species in the Králův Dvůr Formation shows a decreasing diversity toward the top, and a strong but temporary influence by the taxa which appeared in the Prague Basin during the sedimentation of the Perník Bed in the upper part of the formation. It is significant that only several taxa ranging throughout the formation survived above the Perník Bed. They are interpreted as opportunistic, based on such a distribution pattern. All taxa first appeared in the Perník Bed interval (supposed immigrants), and a part of the basin dwellers prior to the sedimentation of the Perník Bed sedimentation disappeared. Such a distribution pattern is interpreted by cooling accompanied by fluctuations in the latest Katian, which is in agreement with the generally accepted model of strong climatic changes in this stratigraphic interval. Analysis of the genera distribution clearly demonstrates the very close relationship of ostracod associations recorded in the Králův Dvůr Formation to Baltica and noticeably weaker migration among the Prague Basin, Avalonia and Laurentia. - Key words: ostracods, Ordovician, Katian, early Hirnantian, Prague Basin, biogeography.
\end{abstract}

Lajblová, K. \& Kraft, P. 2018. Middle Katian/lowermost Hirnantian ostracods from the Prague Basin (Czech Republic): Diversity responses to the climatic changes. Bulletin of Geosciences 93(2), 205-245 (9 figures, 29 tables). Czech Geological Survey, Prague. ISSN 1214-1119. Manuscript received May 22, 2017; accepted in revised form November 3 , 2017; published online June 30, 2018; issued June 30, 2018.

Karolina Lajblová \& Petr Kraft, Institute of Geology and Palaeontology, Faculty of Science, Charles University, Albertov 6, 12843 Prague 2, Czech Republic; lajblova@natur.cuni.cz, kraft@natur.cuni.cz

Although ostracods occur almost in all formations throughout the Ordovician in the Prague Basin (Bohemia, Czech Republic; Fig. 1) they have been studied only occasionally. Historically, they were under-collected in comparison with many other fossil groups and their collections have been very limited. In addition, prevailing siliciclastic facies in the Bohemian Ordovician control the generally unfavourable preservation limiting their study. Ostracods are also of a variable abundance in the stratigraphic units and facies. That is why they are better known in some parts of the Ordovician succession while omitted in others. Altogether, they have attracted only limited attention in general. The Upper Ordovician Králův Dvůr Formation (Fig. 2) is among the units with locally abundant ostracods that were basically described but not yet studied in detail. As this formation deposited during the significant period of climatic changes preceding and commencing the Late Ordovician glaciation (e.g. Štorch \& Mergl 1989; Havlíček 1998; Mergl 2011a, b), this unit has yielded a responding succession of the fossil associations (e.g. Havlíček 1982, Budil et al. 2011b). The role of ostracods including the changes in their associations and distributions in this critical interval is examined in this study as a contribution to the puzzle of arguments on the course of the Late Ordovician global cooling. The Králův Dvůr Formation provides proper datasets, both lithological and palaeontological, particularly in its upper part. The thin carbonaceous layer of the Perník Bed and the overlying shale (Fig. 2) are of key importance from this point of view. Therefore, the first comprehensive systematic study of the ostracods from these intervals provides a dataset supporting 
a construction and test of a detailed climatic model of the northern peri-Gondwana.

Ostracods are among the most common fossils in the Králův Dvůr Formation in general. It is a group known from many localities with a variable diversity of other groups. They are frequently associated with trilobites, brachiopods and various molluscs (Havlíček \& Vaněk 1966). On the other hand, ostracods are even known from almost barren sites with a very scarce or poor fossil record. In spite of this, they have been of very limited interest to collectors even in the case of exceptional ostracod assemblages in the studied formation. The material we had available comes from institutional as well as private collections. However, we expect that it is only a part of collected specimens because frequent specimens are supposed to be associated in clusters with other fauna on slabs. Such samples are registered in the databases of palaeontological collections under other, preferentially collected taxa without any remark about accompanied ostracods. However, the number of species, compared with previous studies, has principally increased, illustrating an exceptional diversity of ostracods in the Králův Dvůr Formation.

Ostracods of the Králův Dvůr Formation have been studied sporadically. Barrande (1872) was the first who systematically studied ostracods from the Early Palaeozoic of Bohemia (now the Czech Republic), including those from the "bande (zone) d5" corresponding to the modern Králův Dvůr Formation. He described seven species (in original spelling with full generic names and updated nomenclature in square brackets): Beyrich. hastata. Barr. [abbrev. Beyrichia; Hastatellina hastata], Beyrich? barbara. Barr. [abbrev. Beyrichia?; = "Beyrichia" barbara], Crescentilla pugnax. Barr., Cytherops. derelicta. Barr. [abbrev. Cytheropsis], Entom. rara. Barr. [abbrev. Entomis; ="Entomozoe" rara], Primit. fugax. Barr. [abbrev. Primitia; = Cytherellina? fugax], Primit. prunella . Barr. [abbrev. Primitia $;=$ Parapyxionella prunella]. Note the B.? barbara is nomen dubium according to Prribyl (1979), and the authors of this paper share this opinion; E. rara is the similar case and its assignment to ostracods is rather questionable; $B$. hastata and C. pugnax was proved to absent in the Králův Dvưr Formation; and C. derelicta is not an ostracod (see below). This information was commonly repeated in subsequent papers (see below). In fact, Barrande (1872) described only two undoubted ostracod species from the Králův Dvůr Formation.

However, Bigsby (1868) used information from the prepared manuscript of J. Barrande and listed two abovementioned species of the genus Primitia in the Addendum of his Thesaurus Siluricus as nomina nuda: Primitia gregaria Barr. from Königshof and Primitia prunella Barr. from Mt. Kosow (both in original spelling). These data were repeated by Jones \& Holl (1869). Thus, the earliest published information about ostracods from the Králův Dvůr Formation, including their determination, preceded their formal description. It is partly confusing because Barrande (1872) synonymized $P$. gregaria with $P$. prunella.

Thereafter ostracods of the studied formation were only occasionally mentioned in the papers, usually as a part of information on localities or the stratigraphic unit, generally as a group and often referred to as 'abundant' (e.g. Chlupáč 1951a; Röhlich \& Chlupáč 1952; Chlupáč 1953; Havlíček 1982; Havlíček \& Mergl 1982; Štorch \& Mergl 1989; Havlíček 1998; Fatka \& Mergl 2009; Mergl 2011a, b). If the material is identified, only Barrande's (1872) original species were quoted and listed (e.g. Bouček 1928, Chlupáč 1951b, Röhlich \& Chlupáć 1952). In principle, revisions of classifications (without systematic studies) and stratigraphic ranges were main changes in subsequent studies and lists such as by Havlíček \& Vaněk (1966) who mentioned (in original spelling) Parapyxion prunellus (Barr.), Parapyxion (?) fugax (Barr.), "Beyrichia" barbara Barr., Ceratopsis hastata (Barr.), Crescentilla pugnax Barr., "Cytheropsis" derelicta (Barr.), "Enthomozoe" rara (Barr.), Mirochilina jonesiana Schmidt, Paraschmidtella (?) densipunctata Schm. and Ulrichia bicornis (Jones) in their faunal list of the Králův Dvůr Formation, which is a compilation of species established by Barrande (1872) supplemented with three taxa described by Schmidt (1941) from the underlying Bohdalec Formation and supposed to range higher in the section.

Krůta (1968) described a new genus Orechina and two new species, both from the Králův Dvůr Formation. These taxa were revised by Schallreuter \& Krůta (1987), O. punctata Krůta, 1968 was accepted as valid while $O$. nuda Krůta, 1968 was reclassified and renamed as Easchmidtella nudista Schallreuter \& Krůta, 1987.

Prribyl (1979) revised extensive material from the Ordovician in his monograph and listed the species occurring in the Králův Dvưr Formation as follows (in original spelling): Crescentilla vaneki sp. n., Parapyxionella prunella (Barrande, 1872), Cytherellina (?) fugax (Barrande, 1872), Entomozoe rara (Barrande, 1872) and "Beyirichia" barbara Barrande, 1872. Two species, Orechina puncata Krůta, 1968 and O. nuda Krůta, 1968, Prribyl (1979) mentioned in the formation with reserve. In principle, he modified Barrande's (1872) ostracod diversity in the Králův Dvưr Formation, extended by one new taxon (and tentatively with two Krůta's species). He found part of Barrande's taxa to occur in the underlying formations and considered Cytheropsis derelicta to be erected based on a deformed trilobite cranidium (p. 54).

Schallreuter \& Krůta (1984) described a new species Platybolbina runica from the Králův Dvůr Formation. Subsequently, Schallreuter \& Krůta (1988) were the last authors to summarize the knowledge about ostracods of the Ordovician of the Prague Basin, including those from the Králův Dvůr Formation. They listed the following species from the studied unit (in original spelling including their original synonymy in square brackets and formal 


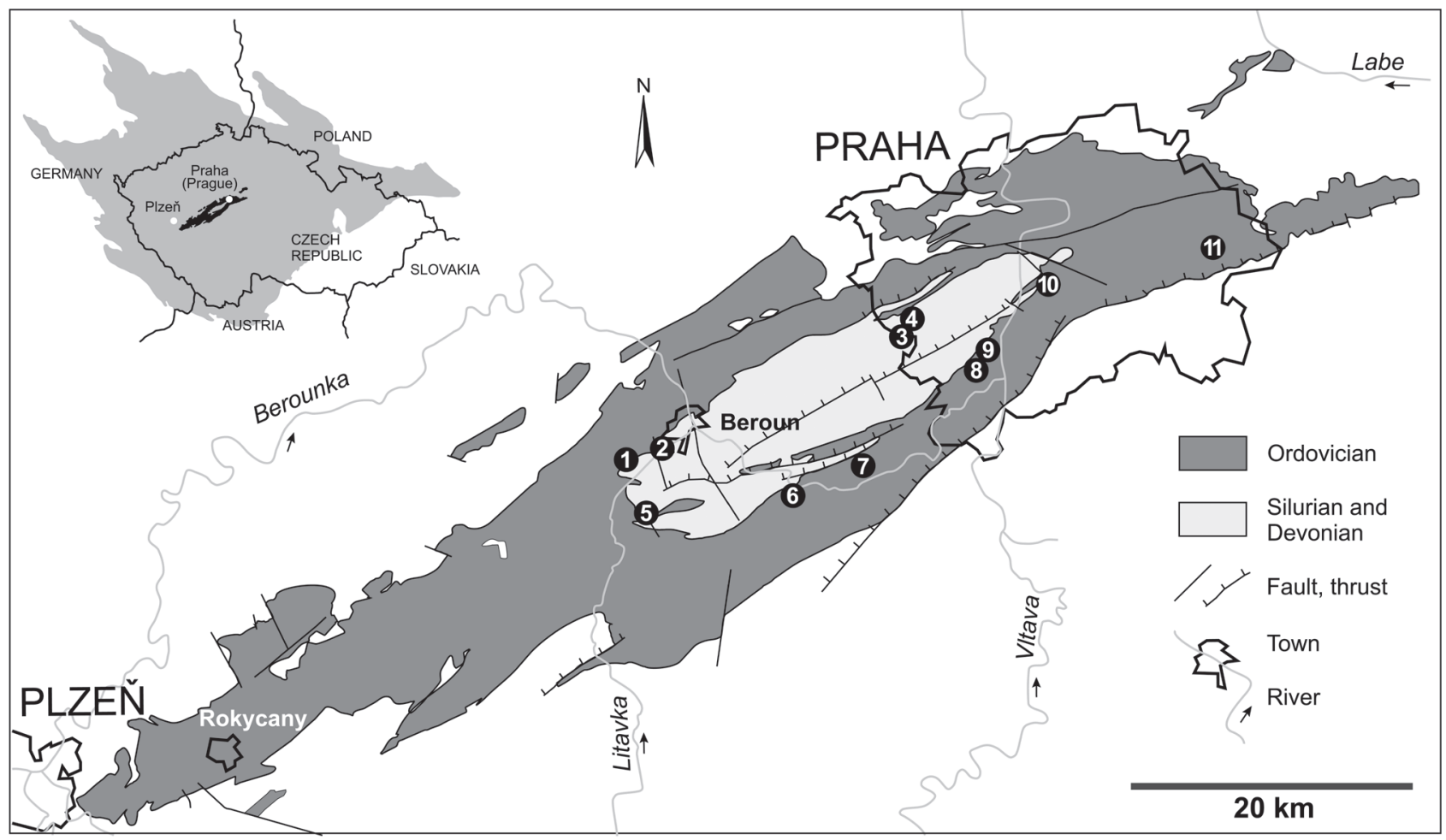

Figure 1. Sketch map of the Prague Basin relic and localities which yielded the studied ostracods. Location of the Prague Basin on the territory of the Czech Republic and the Bohemian Massif (grey) in top left corner. Abbreviations: 1 - Levín - slope above the highway; 2 - Králův Dvůr and Kosov; 3 - Ořech - dug out well on the land of the house no. 51 at the northern edge of the village, and Ořech - borehole at the northern edge of the village (depth 7 m); 4 - Praha-Řeporyje; 5 - Lejškov near Málkov; 6 -Zadní Třebaň - railway cut; 7 - Karlík; 8 - Praha-Radotín - highway tunnel; 9 - PrahaVelká Chuchle - slope above the hippodrome; 10 - Praha-Nusle - Jezerka; 11 - Praha-Běchovice.

mistakes): Primitia gregaria Barrande, MS (nom. nud.), "Beyrichia"? barbara (Barrande, 1872), Cytherellina fugax (Barrande, 1872), Parapyxionella prunella (Barrande, 1872), Entomozoe rara (Barrande, 1872), Orechina punctata Krůta, 1968, Platybolbina runica Schallreuter \& Krůta, 1984, Easchmidtella nudista Schallreuter \& Krůta, 1987 [= Orechina nuda Krůta, 1968], Crescentilla vaneki, Ceratopsis hastata $[=$ ? Hastatellina posthastata $]$, Mirochilina jonesiana, UIrichia bicornis, Orechina densipunctata: Havlíček \& Vaněk [= ? Orechina punctata], Entomis migrans and Scanipisthia rectangularis. These taxa were mentioned without any systematic revision; note an apparent mistake in case of the Silurian E. migrans, which could arise from misunderstanding the information by Barrande (1872, p. 514). In addition, they described a new subspecies Uhakiella linnarssoni barrandensis from Ořech, the type locality of Orechina punctata. However, they stated its origin from the Králův Dvůr Formation with doubts. Finally, Schallreuter \& Krůta (1990) supplemented the revision of Scanipisthia rectangularis (Troedsson) with figured specimens from the studied formation of the Prague Basin.

Note that no ostracods from the Perník Bed have been studied in detail, although their common occurrence in this unit was known long ago (e.g. Havlíček 1982) and only very limited material from shale overlying the Perník Bed is considered to have been described (possibly Parapyxionella prunella from Zadní Třebaň by Přibyl 1979).

\section{Geological and palaeontological settings}

The Králův Dvůr Formation (established by Lipold \& Krejčí 1860; for a historical overview see Chlupáč 1999 and for extended synoptical correlation see Gutiérrez-Marco et al. 2017) is a distinct unit of the Upper Ordovician in the Prague Basin (Havlíček 1981). It is represented by the predominating monotonous, often intensively bioturbated succession of grey to greyish-green shale with silt admixture (Havlíček 1998) and a low content of organic matter reaching up to $0.3 \%$ (Kraft et al. 2015). This light shale replaces the black shale typical of the underlying Bohdalec Formation. That lithological change is prominent in the socalled Mediterranean province (Spjeldnaes 1961, Havlíček 1989).

The Podolí Iron Ore Horizon (established by Šuf \& Prantl 1946) is locally developed at the base of the Králův Dvưr Formation. Dark grey shale of the "Lejškov facies" is typical for the lower portion of the formation in its south-western 
outcrop area. The main focus of this paper is, however, on other facies. The main thickness of the formation is formed by the shale, originally grey, but greyish-green to brownishgreen when weathered (levels A1 and A2 by Štorch \& Mergl 1989). This shale is well documented in the middle and upper parts of the formation as indicated by a number of localities in this facies listed below. The shale locally contains levels with calcareous nodules, especially in its upper part. In the top of the formation, there is developed a very typical carbonaceous shale layer of 5-20 cm thickness which is called the Perník Bed (Brenchley \& Štorch 1989) after the character of the weathered rock (level B1 of Štorch \& Mergl 1989). This significant correlative layer is overlain by brownish-green and grey silty shales (respective levels B2 and C of Štorch \& Mergl 1989). The overall thickness of the formation is up to $200 \mathrm{~m}$ (Havlíček 1981) and terminates on the base of the lower diamictite layer marking the base of the overlying Kosov Formation (Fig. 2).

The biostratigraphy of the Králův Dvůr Formation was recently revised by Kraft et al. (2015). They established an informal interval with Anticostia teres and Styracograptus lobatus, and Dicellograptus laticeps Zone in the main thickness of the formation. There is no graptolite zone recognised inside the Perník Bed and several metres below. Metabolograptus ojsuensis Zone is represented by a thin layer just above the Perník Bed (Fig. 2). The base of this zone is considered as a base of the Hirnantian (Kraft et al. 2015, discussed by Gutiérrez-Marco et al. 2017).

Fossils of the Králův Dvůr Formation are diversified with the dominance of benthic taxa; the number of species is high relative to other units of the Prague Basin (Havlíček $\&$ Vaněk 1966). Trilobites and brachiopods are among the most common groups. Differences in the stratigraphic and lateral occurrences of their species or group of species have been bases for designation of several fossil associations (sensu Budil et al. 2011b). Havlíček (1982, 1989, 1998) characterised the brachiopod associations (communities in his sense), Budil et al. (2011b) revised the concept of trilobite associations in the Králův Dvůr Formation (Havlíček \& Vaněk 1966, Havlíček 1998).

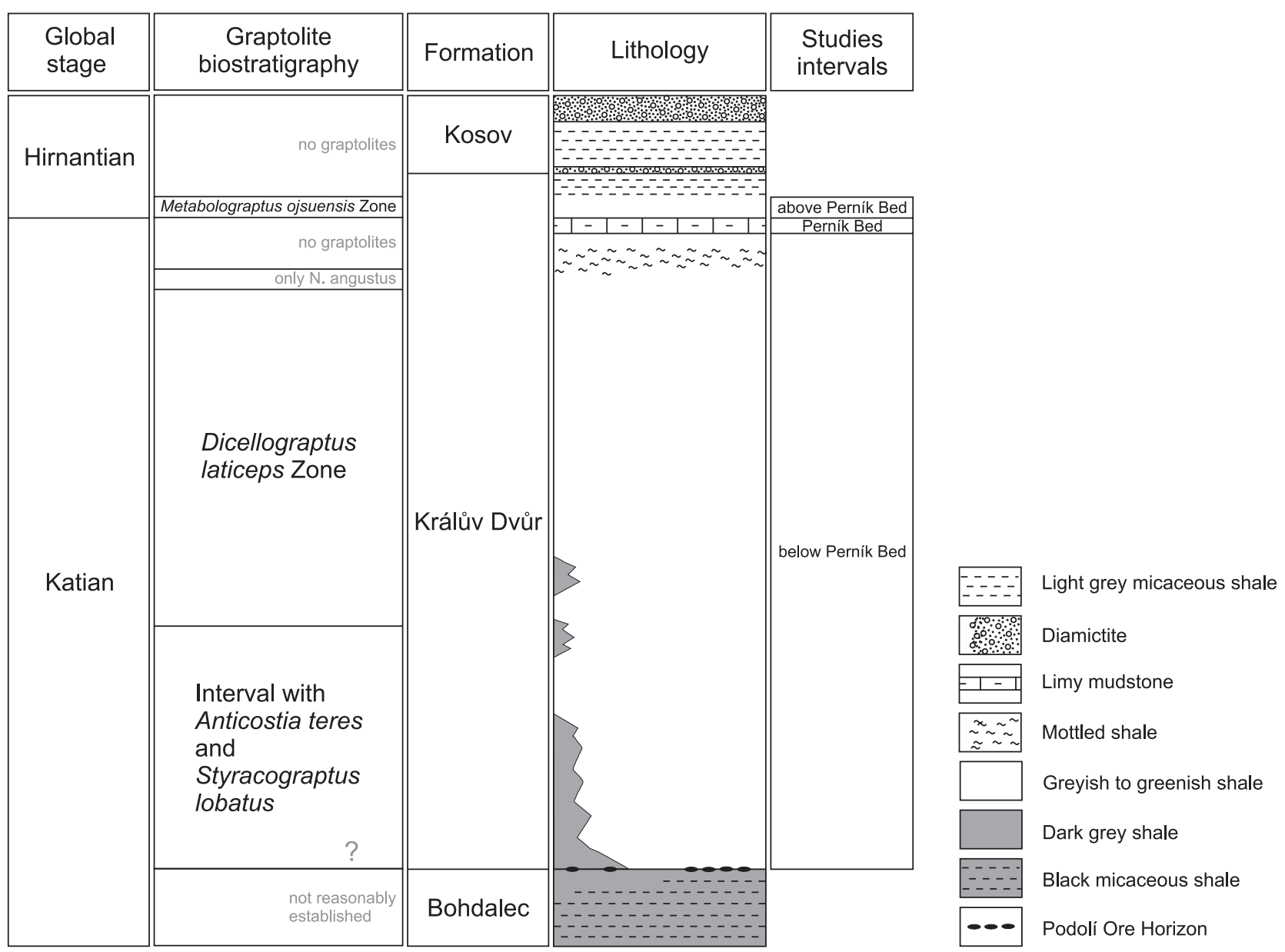

Figure 2. Stratigraphy and general lithology of the Králův Dvůr Formation after Kraft et al. (2015) with ranges of the intervals used for the study of ostracods. Note that the figure is a general illustration and relationships of units are related neither to their exact thicknesses nor time spans of their formation. 
Havlíček (1982) suggested deep-water associations in the formation in general. He distinguished three brachiopod associations in the main thickness of shale below the Perník Bed: Rafanoglossa leiskowiensis, Dedzetina macrostomoides, both benthic associations, and epiplanktic Chonetoidea radiatula Association. The Probosciambon Association is typical for the Perník Bed. No brachiopod associations are established above the Perník Bed. This is why Štorch \& Mergl (1989) combined both groups in the uppermost part of the formation.

Budil et al. (2011b) defined the "Podolí Ore Horizon" and Amphitryon-Kloucekia trilobite associations, the latter with four sub-associations. The Amphitryon-Kloucekia Trilobite Association is confined to the grey shales below the Perník Bed. The Marekolithus kosovensis Trilobite Association is typical for the Perník Bed and Mucronaspis Trilobite Association for the shales above in the uppermost portion of the formation.

\section{Localities}

We had ostracods available from a relatively limited number of localities. However, we consider this fact to be a sampling bias as stated above. Brief comments to the localities listed in occurrences herein (Fig. 1) are as follows:

Lejškov near Málkov. - This locality was studied already by J. Barrande. He described (Barrande 1872) Entomis rara and Primitia prunella from Lejškov (Leiskow in original spelling). The exact site where ostracods were collected together with associated rich fauna of the Králův Dvůr Formation, has been, however, forgotten. The material available for this study was recently collected in a gorge $1.4 \mathrm{~km}$ west-south-west of Málkov and $1.3 \mathrm{~km}$ north-east of the railway station in Libomyšl from a different facies of probably younger age (GPS coordinates: $49^{\circ} 53^{\prime} 04.6^{\prime \prime} \mathrm{N}$, $14^{\circ} 00^{\prime} 12.3^{\prime \prime} \mathrm{E}$; for details see Budil et al. 2011a and Kraft et al. 2015). The locality is also mentioned by Prribyl (1979) who described Parapyxionella prunella from there. Note that he stated the name of the locality in the occurrence paragraph followed by specification of the locality area. The form of his text is confusing and there is no other unspecified locality between Libomyšl and Chodouň as a separate list item.

Levin - slope above the highway. - The high slope above the D5 highway is an artificial road-cut in the Lucberk Hill south-east of Levín Village, $0.75 \mathrm{~km}$ east of the chapel in Levín, $1 \mathrm{~km}$ south-west of the bridge over the highway at the D5 exit 22. (Coordinates for one of the collector pits read from the map: $49^{\circ} 55^{\prime} 42.6^{\prime \prime} \mathrm{N}, 14^{\circ} 00^{\prime} 43.8^{\prime \prime} \mathrm{E}$ ). The locality has yielded rich fossil material from the middle and upper part of the formation (Mergl \& Vohradský 2000).
Ostracods were usually collected in collector pits dug out in place with abundant fauna.

Karlík. - Přibyl (1979) described Parapyxionella prunella from this locality. It is almost sure that it was collected on the hillslope north-east of the village, the only outcrop of the Králův Dvưr Formation near the village described in detail by Chlupáč (1951a).

Králův Dvůr and Kosov. - Králův Dvůr (Koenigshof in original spelling) and Kosov (Mt. Kosow or Mont Kosow in original spelling) are two historical localities studied by Barrande (1872) who described Beyrichia hastata, B.? barbara, Crescentilla pugnax, Cytheropsis derelicta, Primitia fugax, P. prunella from Králův Dvůr and Beyrichia hastata, Primitia prunella from Kosov. Since that no information about new material was published, exposures disappeared and their exact locations were forgotten. However, they were supposedly situated close to each other on the south-eastern margin of Králův Dvưr, probably near the crossing of Tovární Street and the road to Suchomasty (No. 11524).

Orech - dug out well on the land of the house no. 51 at the northern edge of the village and Ořech - borehole at the northern edge of the village (depth $7 \mathrm{~m}$ ). - The borehole was placed later during the mapping near the former locality (M. Krůta personal communication). Only some isolated specimens described by Krůta (1968) from the former locality and the material of Schallreuter \& Krůta (1988) from the latter site were available for our study. Neither its stratigraphic position nor lithology is clear. However, it should be noted that a bore was recently drilled in Ořech. Its whole thickness was represented by the greyish shale of the Králův Dvůr Formation; the Perník Bed was not recorded at the top. As the trilobite Amphitryon was found in the shale it is beyond doubt that part of the formation below the Perník Bed occurs in this area. On the other hand, Uhakiella barrandensis, found typically here was probably identified in the Perník Bed at Zadní Třebaň. Thus, an unspecified upper part of the formation would also be expected to yield the studied material. Summarized, there are species found exclusively at this locality [Pseudulrichia risumata sp. nov., Orechina punctata Krůta, 1968 and Easchmidtella nuda (Krůta, 1968)] illustrating its special position among localities which yielded the ostracods. On the other hand, there are also species known from other sites of the formation. Thus this locality seems to belong to the Králův Dvůr Formation but can represent a distinctive stratigraphic level and/or fossil association.

Praha-Běchovice. - An unspecified site from which Přibyl (1979) described Parapyxionella prunella. The Králův Dvůr Formation can be traced at the west, north-west and north 
parts of Běchovice. Ostracods were probably collected in a temporary excavation.

Praha-Nusle - Jezerka. - Temporary excavations in the Jezerka Park. According to mediated information of V. Havlíček by M. Mergl (personal communication) the material was collected near the small lake east of the Na Jezerce Theatre, west of the locality described by Havlíček \& Mergl (1982).

Praha-Radotin - highway tunnel. - The material was collected during the digging of the Lochkovský tunel (Lochkov Tunnel) on the highway D0. The Králův Dvůr Formation occurs in the south-eastern part of the tunnel (for details see Štorch et al. 2009).

Praha- ̌̌eporyje. - This locality was mentioned by Přibyl (1979). He recorded only Parapyxionella prunella there. The exact place of the locality is unknown. However, it is presumed that he studied the material from the former Reiser's Brickyard which was situated near the north-western edge of Řeporyje (Röhlich \& Chlupáć 1952).

Praha-Velká Chuchle - slope above the hippodrome. - The high slope above the railway Praha-Beroun (No. 171), east of Velká Chuchle. Outcrops of the Králův Dvůr Formation are located above the former Waltr's Gardening Market (U Valtrů on modern maps) as described in detail by Chlupáč (1951b). He measured the extensive section of the Králův Dvurr Formation and recorded ostracods in its middle parts. He suggested a variety of species but Prribyl (1979) mentioned only Parapyxionella prunella.

Zadní Třebañ - railway cut. Outcrops just above the curve of the railway Zadní Třeban̆-Lochovice (No. 172) near the western margin of Zadní Třeban̆, $\sim 0.5 \mathrm{~km}$ south-south-west of the railway station Zadní Třebaň (1 km by rail), northeast of the railway bridge above K Vatinám Street (GPS coordinates: $\left.49^{\circ} 54^{\prime} 52.1^{\prime \prime} \mathrm{N}, 14^{\circ} 12^{\prime} 17.7^{\prime \prime} \mathrm{E}\right)$. The section of the uppermost part of the Králův Dvưr Formation described in detail by Chlupáč (1951a) who mentioned undetermined ostracods from the Perník Bed and the interval above. Although it is very probable that Přibyl (1979) studied the material from the same place as Chlupáč (1951a), as deduced from his locality specification, he quoted only Parapyxionella prunella.

\section{Material and methods}

The present paper is based on material counting altogether hundreds of studied specimens obtained from 13 localities and housed in the collections of the Czech Geological Survey in Prague (specimens with prefix CGS), the National Museum in Prague (NM), the Faculty of Science, Charles University in Prague (FSCU) and the West Bohemian Museum in Pilsen (not figured).

The specimens preserved in shaly sediments under and above the Perník Bed appear either as internal or external moulds, exceptionally with silicified carapaces. However, the poor mode of ostracod preservation, hygroscopic nature of the rock when it softens upon contact with the water and disintegrates, and its fragility did not allow us to coat the rock with ammonium chloride. The material described by Krůta (1968), Schallreuter \& Krůta $(1988,1990)$ and herein from the localities Ořech and Jezerka, Prague, were washed out. A part of samples from the Perník Bed was disintegrated by means of sodium hyposulphite with repeated heating and cooling process, another part was dissolved by means of acetic acid. The specimens were examined under the optical microscope and photographs were taken with a scanning electron microscope JEOL JSM-6380LV in the Institute of Geology and Palaeontology, Charles University in Prague, a scanning electron microscope Hitachi S-3700N and a digital microscope Keyence VHX-2000, both in the National Museum in Prague. The software Past (Hammer et al. 2001) was used for calculations of similarity indexes.

\section{Systematic Palaeontology}

Specifications of type localities and occurrences are related to the most accurate data we had available on stratigraphy. Because of the uncertain stratigraphic position of many specimens from the thick succession of the grey to greyish-green shale, a practical approach was decided: the occurrences of taxa are characterised relative to the Perník Bed and related to three intervals - below, inside and above the Perník Bed (Fig. 2). Thus, the prominent lithological unit containing a distinct fossil association (see above) clearly traceable in the field is used as a key marker.

The used terminology of size ratio and proportions was summarised by Schallreuter \& Hinz-Schallreuter (2010). The classification of Meidla (1996) is applied as the basis for systematics.

Morphological abbreviations: $\mathrm{L}$ - maximum length of the valve; $\mathrm{H}$ - maximum height of the valve; $\mathrm{L}: \mathrm{H}$ - length/ height ratio; $\mathrm{L}_{\mathrm{D}}$ - maximum length of the domicilium; $H_{D}$ - maximum height of the domicilium; $L_{D}: H_{D}$ - length of the domicilium/height of the domicilium ratio; $\mathrm{H}_{\mathrm{S}}$ - height of the valve including spine; $\mathrm{N}_{2}$ - preadductorial node; $\mathrm{S}_{2}$ - adductorial sulcus; $\mathrm{LV}$ - left valve; $\mathrm{RV}$ - right valve.

Class Ostracoda Latreille, 1802

Order Beyrichiocopida Pokorný, 1954

Suborder Palaeocopa Henningsmoen, 1953

Superfamily Hollinacea Swartz, 1936

Family Tvaerenellidae Jaanusson, 1957 


\section{Genus Uhakiella Öpik, 1937}

Type species. - Uhakiella coelodesma Öpik, 1937; Middle Ordovician, Estonia.

Uhakiella barrandensis Schallreuter \& Krůta, 1988 Figure 3A, B; Table 1

1988. Uhakiella linnarssoni barrandensis ssp. n.; R. Schallreuter \& M. Krůta, pp. 106, 107, pl. 4, figs 2, 3.

Holotype. - Isolated incomplete heteromorphic carapace, NM L 28813, originally designated and figured by Schallreuter \& Krůta (1988, pl. 4, fig. 2) and refigured herein in Fig. 3A.

Paratype. - Isolated incomplete juvenile carapace, NM L 28814 , originally designated and figured by Schallreuter \& Krůta (1988, pl. 4, fig. 3) and refigured herein in Fig. 3B.

Type horizon and locality. - Králův Dvůr Formation, below the Perník Bed interval; Králodvorian, upper Katian. Ořech borehole at the northern edge of the village, Czech Republic; Prague Basin.

Material. - 2 incomplete carapaces and 1 fragment.

Diagnosis. - Valves of medium size and high shape. Outline amplete in juvenile specimen. Adductorial sulcus $\mathrm{S}_{2}$ relatively shallow. Anterior dolon faintly convex. Ventrally located furrow between lateral surface of domicilium and dolon. Very fine reticulation.

Description. - The outline of the valve is rather amplete. The dorsum is distinctly orthocline. The dorsal margin is straight and relatively short, the structure of a hinge is unknown. Cardinal angles are obtuse in the juvenile; the anterior one is obtuse also in adult heteromorph. Dorsal plica cannot be distinguished in available specimens. The carapace possesses a broad V-shaped $\mathrm{S}_{2}$ near the mid-length in the juvenile specimen with its ventral end situated at midheight. In the holotype specimen, $\mathrm{S}_{2}$ is curved anteroventrally. A weakly developed adductorial pit is rounded. In the paratype specimen the anterior half is a bit more inflated than the anterior one. The supposed heteromorphic valve has a weakly convex dolon (= false pouch) in the anterior part of the valve. The dolon terminates approximately at the same height as the ventral end of the sulcus. Juvenile valve

Table 1. Uhakiella barrandensis Schallreuter \& Krůta, 1988, dimensions $(\mathrm{mm})$ and proportions of figured specimens.

\begin{tabular}{lccccr}
\hline Specimen & Valve & Figure & L & H & L:H \\
\hline NM L 28813 holotype & RV & 3A & $>1.66$ & 1.60 & $>1.03$ \\
NM L 28814 paratype & LV & 3B & 1.71 & 1.17 & 1.46 \\
\hline
\end{tabular}

has a subvelar field along the entire free margin, reaching a maximum width of $0.22 \mathrm{~mm}$. The marginal rim, parallel to the velar one, is visibly denticulate. Fine reticulation covers the entire lateral surface.

Discussion. - Uhakiella barrandensis Schallreuter \& Krůta, 1988 seems to be very close to Uhakiella linnarssoni (Hennisgsmoen, 1948) from Västergötland in Sweden (Henningsmoen 1948, pl. 25, fig. 11), but differs in having shallower sulcus, a wider subvelar field and velar ridge without any striae. In $U$. barrandensis the laterovelar furrow between the dolon and lateral surface of the domicilium is less developed, as well as the median and posterior lobes which are distinctly surrounding the sulcus in $U$. linnarssoni. The strongly convex dolon, which is a typical feature of Uhakiella species, is not present in U. barrandensis as its convexity is much less pronounced. According to these morphological differences, the authors decided to place Bohemian material in the individual species and not subspecies, as did Schallreuter \& Krůta (1988).

Occurrence. - Interval below the Perník Bed: Ořech borehole at the northern edge of the village (depth $7 \mathrm{~m}$ ); the Perník Bed: one questionable isolated fragment from Zadní Třebaň - railway cut.

\section{Genus Euprimites Hessland, 1949 \\ Subgenus Euprimites (Euprimites) Hessland, 1949}

Type species. - Euprimites reticulogranulata Hessland, 1949; Middle Ordovician, Sweden.

\section{Euprimites (Euprimites) kralodvorensis sp. nov.} Figures 3F, 6A, B; Table 2

Holotype. - Incomplete left valve on a slab, CGS KL 144 (Fig. 6A).

Paratype. - Incomplete right valve on a slab, CGS KL 154 (Fig. 6B).

Type horizon and locality. - Králův Dvůr Formation, below the Perník Bed interval; Dicellograptus laticeps Zone; Králodvorian, upper Katian. Praha-Radotín - highway tunnel, Czech Republic; Prague Basin.

Material. - More than 150 specimens on rock slabs, some with a well preserved fossilized surface, 5 carapaces (internal moulds) and 3 fragments.

Etymology. - After the formation of its occurrence.

Diagnosis. - Large unisulcate valves. Dorsal margin straight and relatively long. Adductorial sulcus deep and directed 
anteroventrally. Small $\mathrm{N}_{2}$ developed. Distinct velar ridge along free margin, subvelar field wide in holotype, with the maximum width anteriorly. Lateral surface reticulated except for $\mathrm{S}_{2}$.

Description. - The outline of the carapace is amplete to slightly postplete, valves are large sized (up to $2.25 \mathrm{~mm}$ ) and rather high. The dorsal margin is straight and relatively long, cardinal angles are obtuse with the posterior one bigger than the anterior one. The dorsum is clearly orthocline. Anteroventrally directed sulcus $\mathrm{S}_{2}$ is prominent, extending from the dorsal margin to the mid-height of the valve. It is deep, rather broad, ventrally widened and surrounded by a distinct narrow horseshoe-shaped ridge. The distinct preadductorial node $\mathrm{N}_{2}$ in the mid-height of $\mathrm{S}_{2}$ is small and faintly extending into the sulcus. The valves are moderately convex, the area behind the sulcus is slightly more convex. The ventral part of the valve is more swollen. Some specimens possess a narrow velar ridge along the entire free margin; the subvelar field is slightly concave. The ridge is present already in comparatively young instars. The subvelar field in holotype is slightly concave, forming a dolon-like structure anterodorsally, approximately at the same height as the dorsal part of $\mathrm{S}_{2}$, sloping moderately to the ventral part of the valve and terminating in the posterior part of the dorsal margin. The anterior part of the dolonal field is very wide, narrowing ventrally. The lateral surface is distinctly reticulate except for the sulcus, which is smooth.

Table 2. Euprimites (Euprimites) kralodvorensis sp. nov., dimensions $(\mathrm{mm})$ and proportions of figured specimens.

\begin{tabular}{lccccc}
\hline Specimen & Valve & Figure & L & H & L:H \\
\hline CGS KL 144 holotype & LV & 6A & 2.38 & 1.45 & 1.64 \\
CGS KL 154 paratype & RV & 6B & 2.11 & 1.55 & 1.36 \\
CGS KL 131 & LV & 3F & 1.24 & 0.85 & 1.46 \\
\hline
\end{tabular}

Discussion. - If we consider the specific "dolonal" structure in the holotype specimen, which makes a certain variation within the specimens, to be a dimorphic feature, we may determine the heteromorphic valves in our collection. With regard to the position of the dolon in heteromorphs, $E$. (E.) kralodvorensis sp. nov. differs from the other known
Euprimites species by its more anterior than anteroventral placement, its exceptional width anterodorsally, and by the comparatively larger size of the valves. E. (E.) grandis Olempska, 1994 from the Middle Ordovician of Poland shares a somewhat larger size of the carapace (up to $2.5 \mathrm{~mm}$ ) and nearly amplete outline, but differs mostly in having a completely smooth lateral surface. Euprimites (E.) kralodvorensis also resembles E. (E.) slehoferi Schallreuter \& Krůta, 2001a from the Dobrotivá Formation of Prague Basin in its similar outline, anteroventrally curved $\mathrm{S}_{2}$ and the type of reticulation, but the anterodorsal position of the dolon and its greater width in E. (E.) kralodvorensis make a significant difference between those two species.

Occurrence. - Interval below the Perník Bed, Dicellograptus laticeps Zone: Lejškov near Málkov, Levín - slope above the highway, Praha-Radotín - highway tunnel; the Perník Bed: Zadní Třebaň - railway cut.

Family Tetradellidae Swartz, 1936

Subfamily Perspicillinae Schallreuter, 1967

\section{Genus Sigmobolbina Henningsmoen, 1953}

Type species. - Entomis oblonga var. kuckersiana Bonnema, 1909; Late Ordovician, Estonia.

\section{Sigmobolbina? sp.}

Figure 6C-E, Table 3

Material. -7 more or less incomplete valves on rock slabs, most of them with partly preserved silicified carapace.

Description. - The valves are of a large size (up to $2.5 \mathrm{~mm}$ ) and moderately high. The dorsal margin is straight and almost as long as the maximum length of the valve. The outline is distinctly preplete with a posterior swing. The posteroventral lobe is developed as a distinct inflation of the ventral part of the postadductorial area. The valve possesses a long and relatively broad depression $\mathrm{S}_{2}$, deepest in the anteroventral area and directed middle-dorsally to its broadest part. A distinct and rounded preadductorial node is developed in the front of the sulcus and situated at its

Figure 3. A, B - Uhakiella barrandensis Schallreuter \& Krůta, 1988; A - NM L 28813 (holotype), incomplete heteromorphic carapace, right lateral view; $A_{1}$ - ventral view; $A_{2}$ - anterior view; B - NM L 28814 (paratype), juvenile carapace, left lateral view; $B_{1}$ - ventral view; $B_{2}$ - anterior view. • C, D - Baltonotella? admirabilis sp. nov.; C - CGS KL 8 (holotype), incomplete left? valve, lateral view; $\mathrm{C}_{1}$ - ventral view; D - CGS KL 42 (paratype), incomplete carapace, lateral view; $\mathrm{D}_{1}$ - ventral view; $\mathrm{D}_{2}$ - detail of surface reticulation. $\bullet \mathrm{E}$ - Aechmina? meidlai sp. nov.; CGS KL 63 (holotype), incomplete left valve (with partly broken spine), lateral view; $\mathrm{E}_{1}$ - ventral view; $\mathrm{E}_{2}$ - posterior view. $\bullet \mathrm{F}$ - Euprimites (Euprimites) kralodvorensis sp. nov., CGS KL 131 , isolated carapace (internal mould), left lateral view; $\mathrm{F}_{1}$ - posterior view; $\mathrm{F}_{2}$ - dorsal view; $\mathrm{F}_{3}$ - ventral view. $\bullet \mathrm{G}-$ Parapyxionella prunella (Barrande, 1872), CGS KL 4, incomplete right valve, lateral view. $\bullet$ H, I - Spinigerites ostrovites sp. nov.; H - CGS KL 64 (holotype), incomplete heteromorphic left valve (with partly exfoliated surface including spine), lateral view; $\mathrm{H}_{1}$ - dorsal view; I - CGS KL 66 (paratype), incomplete left valve, lateral view. J - Spinigerites sp., CGS KL 74, incomplete left valve, lateral view; $\mathrm{J}_{1}$ - ventral view. Localities: Ořech - borehole at the northern edge of the village (A, B); Zadní Třebaň - railway cut (the Perník Bed) (C-E, G-J); Lejškov near Málkov (F). All SEM photomicrographs. Uniform magnification. 


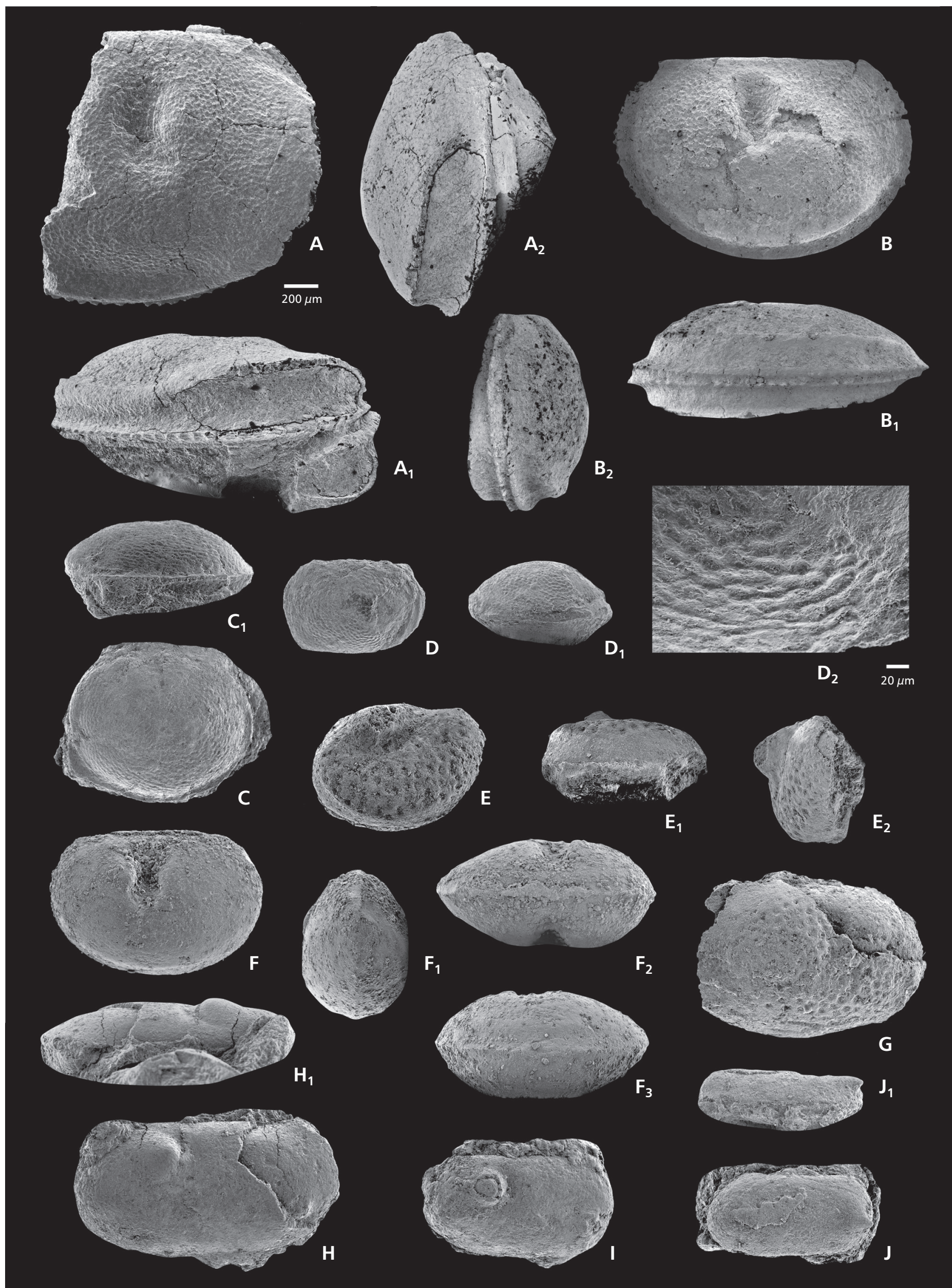


middle-length. The highest convexity is slightly posteroventrally. The valves possess narrow velar flange with a distinct furrow between the flange and lateral surface. This velar structure can be followed from the anterior part of the dorsal margin along the anteroventral area of the valve, but the insufficiently preserved material does not allow further description of the posterodorsal part of the valve. The lateral surface is visibly reticulated in the lateroventral area of one specimen (Fig. 6E). Due to unfavourably preserved specimens with only little fragments of silicified surface available, the internal and dimorphic features of the carapace remain unknown.

Table 3. Sigmobolbina? sp., dimensions ( $\mathrm{mm}$ ) and proportions of figured specimens.

\begin{tabular}{lccccc}
\hline Specimen & Valve & Figure & L & H & L:H \\
\hline CGS KL 207 & LV & 6C & 2.52 & 1.53 & 1.65 \\
CGS KL 226 & LV & 6D & 2.32 & 1.20 & 1.93 \\
CGS KL 161a & RV & 6E & $>2.01$ & 1.27 & $>1.70$ \\
\hline
\end{tabular}

Discussion. - Sigmobolbina? sp. shares similar features with Sigmobolbina vysocanensis Prribyl, 1979 from the Vinice Formation of the Prague Basin, such as the outline, the size of preadductorial node and the form of a sulcal depression. Therefore $S$. vysocanensis may be conspecific with the present material, but the latter species is based only on internal moulds which do not provide any further details of the carapace. The sulcus in S. kolkaensis Gailīte, 1975 from the Upper Ordovician of Baltica is, on the contrary, of similar length, but $S$.? sp. has a distinctly preplete outline and less pronounced velum. Sigmobolbina? sp. may resemble species of other genera from the family Perspicillinae, but more sufficiently preserved material is necessary for the more specific determination.

Occurrence. - Interval below the Perník Bed, Dicellograptus laticeps Zone: Praha-Radotín - highway tunnel; interval above the Perník Bed, Metabolograptus ojsuensis Zone: Zadní Třebaň - railway cut.

Superfamily Eurychilinacea Ulrich \& Bassler, 1923

Family Oepikellidae Jaanusson, 1957

Subfamily Ampletochilininae Schallreuter, 1975

\section{Genus Platybolbina Henningsmoen, 1953}

Type species. - Primitia distans Krause, 1889; Late Ordovician, Germany (erratic boulder).

\section{Platybolbina runica Schallreuter \& Krůta, 1984}

Figure $6 \mathrm{~F}-\mathrm{H}$, Table 4

1984 Platybolbina runica sp. nov.; Schallreuter \& Krůta, pp. 123-126, pls 11/124, 11/126.

1988 Platybolbina runica Schallreuter and Krůta, 1984. Schallreuter \& Krůta, p. 104.

1996 P. runica (Schallreuter and Krůta, 1984). - Meidla, p. 24.

Holotype. - Left heteromorphic valve on a slab, NM L 22740, originally designated and figured by Schallreuter \& Krůta (1984, pl. 11/124, figs 1,2) and refigured herein in Fig. 6F.

Paratype. - Right valve on a slab, NM L 22741 and NM L 22742 , counterparts of the specimen originally designated and figured by Schallreuter \& Krůta (1984, pl. 11/124, fig. 3, pl. 11/126, figs 1-3) and refigured herein in Fig. 6G, H.

Type horizon and locality. - Praha-Nusle - Jezerka, Czech Republic; Prague Basin. (Note that coordinates in the original description are incorrect). Králův Dvůr Formation, below the Perník Bed interval; Králodvorian, upper Katian.

Material. - The holotype (NM L 22740) specimen preserved on a slab, internal mould of the paratype specimen (NM L 22741) and its valve in the rock counterpart (NM L 22742).

Diagnosis. - High, slightly preplete valves with mediumsized non-reticulated and egg-shaped muscle spot. Sulcal depression runs towards the dorsal margin. Moderately wide and striate velar frill along the free margin, in heteromorphs with a weakly convex dolon. Lateral surface distinctly polygonally ornamented.

Description. - The outline of the domicilium is amplete to slightly preplete. The hinge line is almost as long as the greatest length of the domicilium. The anterior cardinal angle is slightly bigger than the posterior one. The pointed posterior cardinal corner field seems to be slightly flattened. The ovate

Figure 4. A-Primitiella? sp., CGS KL 46, isolated carapace (internal mould), left lateral view; $\mathrm{A}_{1}$ - ventral view; $\mathrm{A}_{2}$ - anterior view. $\bullet \mathrm{B}$, $\mathrm{C}$ - Leperditella? sp. A; B - CGS KL 132, isolated carapace (internal mould), left lateral view; $\mathrm{B}_{1}$ - dorsal view; $\mathrm{B}_{2}$ - ventral view; $\mathrm{B}_{3}$ - posterior view; C - CGS KL 136, isolated carapace (internal mould) left lateral view. - D, E - Aviacypris? sp.; D - CGS KL 124, right valve, lateral view; E - CGS KL 51, isolated carapace, dorsal view. $\bullet \mathrm{F}$ - Longiscula sp., CGS KL 37, isolated carapace, left lateral view; $\mathrm{F}_{1}$ - ventral view; $\mathrm{F}_{2}$ - posterior view. $\bullet \mathrm{G}, \mathrm{H}-$ Leperditella? sp. B; $\mathrm{G}$ - CGS KL 45, isolated carapace, left lateral view; $\mathrm{G}_{1}$ - anterior view; H - CGS KL 44, isolated carapace, dorsal view. $\bullet$ I, J - Rectella bublei sp. nov.; I - CGS KL 12 (holotype), isolated carapace, right lateral view; $\mathrm{I}_{1}$ - ventral view; $\mathrm{I}_{2}$ - anterior view; J - CGS KL 15 (paratype), isolated carapace, right lateral view; $\mathrm{J}_{1}$ - dorsal view. $\bullet \mathrm{K}$ - Longiscula $\mathrm{cf}$. perfecta Meidla, 1993, CGS KL 31, partly exfoliated carapace, right lateral view; $\mathrm{K}_{1}-$ ventral view; $\mathrm{K}_{2}$ - anterior view. Localities: Zadní Třebaň - railway cut (the Perník Bed) (A, D-K); Lejškov near Málkov (B, C). All SEM photomicrographs. Uniform magnification. 


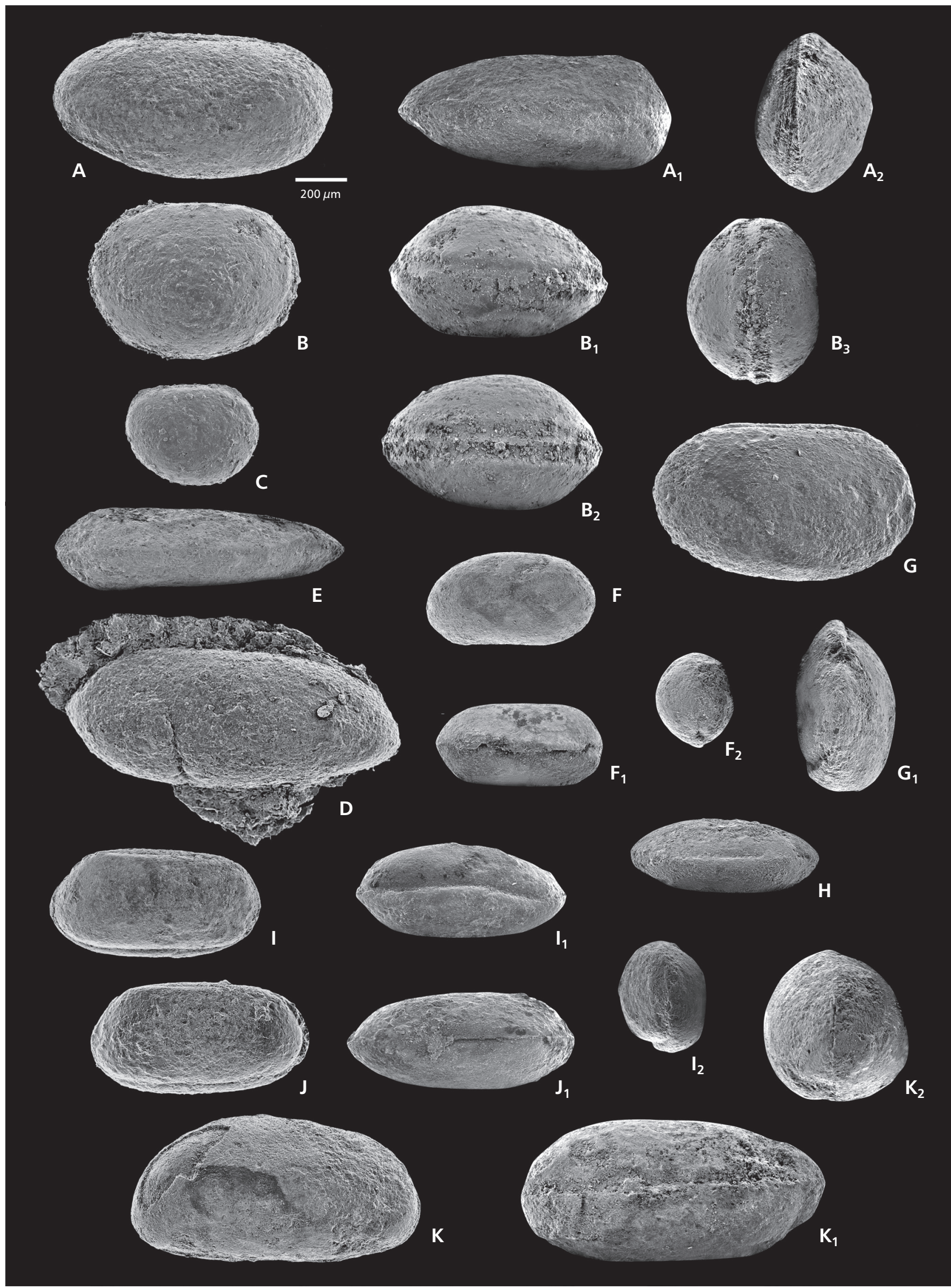


adductorial muscle spot is situated in the central area of the lateral surface of the domicilium and followed by dorsally directed shallow depression. The muscle spot is well defined and represented by several impressions. The anterior part of the domicilium is a bit more inflated than the posterior part. The tecnomorphic valve exhibits a moderately wide and striate velar frill along the entire free margin, most significant in the anterior part. The velar tubules are relatively short and narrow. In the heteromorphic specimen the anteroventrally placed dolon is faintly convex and comparatively broader than the velar frill in the tecnomorphic carapace. The lateral surface of the domicilium is ornamented by small granules polygonally arranged except for the muscle spot and velar structures.

Table 4. Platybolbina runica Schallreuter \& Krůta, 1984, dimensions $(\mathrm{mm})$ and proportions of figured specimens.

\begin{tabular}{lccccc}
\hline Specimen & Valve & Figure & $\mathrm{L}_{\mathrm{D}}$ & $\mathrm{H}_{\mathrm{D}}$ & $\mathrm{L}_{\mathrm{D}}: \mathrm{H}_{\mathrm{D}}$ \\
\hline NM L 22740 holotype & $\mathrm{LV}$ & $6 \mathrm{~F}$ & 2.14 & 1.29 & 1.66 \\
$\begin{array}{l}\text { NM L 22741-42 } \\
\text { paratype }\end{array}$ & $\mathrm{RV}$ & $6 \mathrm{G}, \mathrm{H}$ & 1.61 & 0.99 & 1.62 \\
\hline
\end{tabular}

Discussion. - The carapace of the heteromorphic specimen attains a comparatively large size $(2.4 \mathrm{~mm})$ and since its designation by Schallreuter \& Krůta (1984) is still considered as one of the largest Ordovician species of Platybolbina described. The material studied is preserved at least enough to make some comparisons to other representatives of the genus. Platybolbina runica Schallreuter \& Krůta, 1984 differs from P. (R.) kapteyni (Bonnema, 1909) in the less convex lateral surface, and the higher position of the muscle spot, which is smooth, drop-like and situated closer to the ventral margin in P. (R.) kapteyni (cf. Jaanusson 1957, Sarv 1959, etc.). Some similar features could be traced also to Platybolbina tiara Henningsmoen, 1954 from the Late Ordovician of Estonia (Henningsmoen 1954), but the Bohemian species possesses a significantly narrower and less striate velar frill. On the other hand, Platybolbina (Reticulobolbina) sp. of the same age from Poland (Olempska 1994) shares similar features in outline, shape of the muscle spot and in reticulation. However, the Polish material includes only one incomplete external mould with almost no velar frill preserved. Different subgenera of the genus
Platybolbina were established by Schallreuter (1969) due to a great variability within this particular taxon. However, the Bohemian material counting only two specimens with mainly internal features of the valve cannot be properly revised without additional and better preserved material.

Occurrence. - Interval below the Perník Bed: Praha-Nusle Jezerka.

Family uncertain

\section{Genus Ningulella Warshauer \& Berdan, 1982}

Type species. - Ningulella paupera Warshauer \& Berdan, 1982; Late Ordovician, Kentucky, USA.

\section{Ningulella? sp.}

Figures 5A, 7A; Table 5

Material. - 22 specimens on rock slabs including mainly internal moulds, 3 carapaces (internal moulds).

Description. - The valves are of medium size (up to $1.85 \mathrm{~mm}$ ) and long to very long. The lateral outline of the valves is amplete. The dorsal margin is long and straight, almost parallel to the gently curved ventral margin. No distinct cardinal angles. The anterior end is more or less pointed in some specimens and less rounded than the posterior end. The greatest length is about the mid-height, the greatest height is at the mid-length (both pass through the midpoint of the carapace). The left valve is dorsally higher and slightly overlaps the right one along the free margin. Valves are moderately convex with the central part of the lateral surface rather flattened, sloping steeply to the margins. The lateral surface is smooth.

Discussion. - The studied specimens mostly resemble

Table 5. Ningulella? sp., dimensions (mm) and proportions of figured specimens.

\begin{tabular}{lccccc}
\hline Specimen & Valve & Figure & L & H & L:H \\
CGS PB 1202 & LV & 7A & 1.45 & 0.70 & 2.07 \\
CGS KL 126 & RV & 5A & 0.84 & 0.42 & 2.00 \\
\hline
\end{tabular}

Figure 5. A - Ningulella? sp., CGS KL 126, isolated carapace (internal mould), right lateral view; $\mathrm{A}_{1}-$ dorsal view; $\mathrm{A}_{2}-$ posterior view. B-D - Cryptophyllus sp.; B - CGS KL 82, lateral view; $\mathrm{B}_{1}$ - side view; $\mathrm{B}_{2}$ - lateroventral view; C - CGS KL 91, lateral view; D - CGS KL 84, dorsal view; $\mathrm{D}_{1}-$ side view. $\bullet$ E, F - Easchmidtella nuda (Krůta, 1968); E - FSCU 302 (holotype), isolated carapace, lateral view; $\mathrm{E}_{1}-$ dorsal view; $\mathrm{E}_{2}-$ side view; F- FSCU 306, isolated carapace, lateral view; $\mathrm{F}_{1}$ - dorsal view. $\bullet \mathrm{G}, \mathrm{H}$ - Warthinia trinoda sp. nov.; G - FSCU 260 (holotype), isolated carapace, right lateral view; $\mathrm{G}_{1}$ - dorsal view; $\mathrm{G}_{2}$ - posterior view; $\mathrm{G}_{3}$ - anterolateral view; $\mathrm{H}$ - CGS KL 140 (paratype), isolated carapace (internal mould), left lateral view; $\mathrm{H}_{1}$ - dorsal view; $\mathrm{H}_{2}$ - anterior view. $・ \mathrm{I}-\mathrm{K}$ - Pseudulrichia risumata sp. nov.; I - FSCU 279 (holotype), isolated carapace (internal mould), left lateral view; $\mathrm{I}_{1}$ - dorsal view; J - FSCU 274 (paratype), isolated carapace (internal mould), left lateral view; K - FSCU 271, isolated left valve, anterior view. Localities: Lejškov near Málkov (A, H); Zadní Třebaň - railway cut (the Perník Bed) (B-D); Ořech - dug out well at the northern edge of the village (E, F); Ořech - borehole at the northern edge of the village (I-K). All SEM photomicrographs. Uniform magnification. 


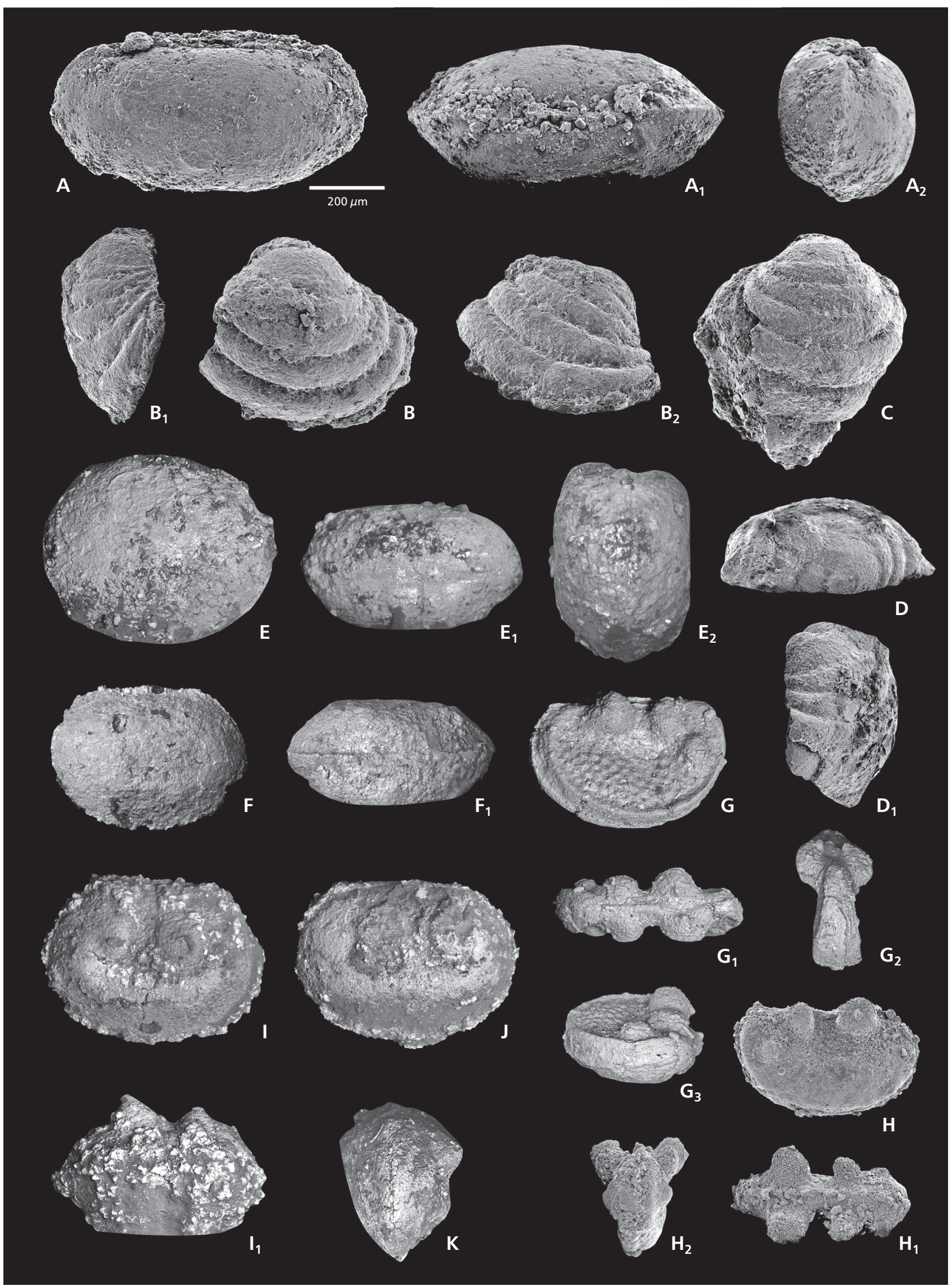


representatives of the genus Ningulella established by Warshauer \& Berdan (1982) for the material from the Upper Ordovician of Kentucky. They pointed out the difference with the genus Primitiella Ulrich, 1894 where Ningulella lacks incipient strangular process and any marginal structures. In Primitiella the left valve overlaps the right, whereas Ningulella has the opposite overlap. Ningulella? sp. may resemble Longiscula sp. described from the same formation, but the overall outline is different. The greatest length is at the mid-height of the valve, which is less convex and the lateral surface is gently sloping to the margins in Ningulella? sp. Warshauer \& Berdan (1982) established two species; the type species $N$. paupera differs from $N$.? sp. by having a rather postplete outline and higher valves and the latter Ningulella sp. possesses a low node in the posterior part near the mid-height. The Ningulella species assigned to this genus by Schallreuter (1999), who revised original material of Primitiella described by Hessland (1949) from the Lower Ordovician of Sweden, are very similar to ours in general outline, convexity and in smooth surface, but differ primarily in the presence of a sulcal depression and in the acute dorsal cardinal angle (e.g. N. brevisulcata, Schallreuter 1999, pl. 1, fig. 3).

Occurrence. - Interval below the Perník Bed, Dicellograptus laticeps Zone: Lejškov near Málkov, Levín - slope above the highway, Praha-Radotín - highway tunnel.

Suborder Binodicopa Schallreuter, 1972

Superfamily Drepanellacea Ulrich \& Bassler, 1923

Family Bolliidae Bouček, 1936

\section{Genus Scanipisthia Schallreuter \& Krůta, 1990}

Type species. - Jonesina rectangularis Troedsson, 1918; Late Ordovician, Sweden.

\section{Scanipisthia rectangularis (Troedsson, 1918)}

Figure 7D-F, Table 6

1918 Jonesina rectangularis n. sp.; Troedsson, pp. 56, 57, fig. 9.

1934 Jonesina rectangularis Troedsson. - Bassler \& Kellett, pp. $72,347$.

1968 Bollia mezmalensis Gailīte; Gailīte, p. 132. [nomen nudum]

1970 Bollia mezmalensis Gailīte, sp. n.; Gailīte, p. 24, pl. 1, fig. 5 .

1982 Bollia mezmalensis Gailīte. - Ulst et al., p. 132.

1984 Bollia mezmalensis Gailīte. - Sarv \& Meidla, pp. 10, 14, 19.

1985 Bollia mezmalensis Gailīte. - Sztejn, pp. 15, 72, pl. 4, fig. 7.

1985 Scanipisthia rectangularis. - Schönlaub, p. 66, fig. 25.
1988 Scanipisthia rectangularis (Troedsson). - Schönlaub, p. 109.

1988 Scanipisthia rectangularis. - Schallreuter \& Krůta, pp. 100, 105.

1990a Scanipisthia rectangularis (Troedsson) - Schallreuter, p. 121, pl. 1, fig. 1.

1990 Scanipisthia rectangularis (Troedsson). - Schallreuter \& Krůta, pp. 89, 91, pls 17/90, 17/92.

1996 Scanipisthia rectangularis (Troedsson, 1918). - Meidla, p. 79, pl. 14, fig. 13.

2009 Scanipisthia rectangularis. - Meidla et al., p. 47.

2011 Scanipisthia rectangularis. - Meidla et al., pp. 354, 355.

2013 Scanipisthia rectangularis. - Meidla et al., p. 351.

2015 Scanipisthia rectangularis (Troedsson). - Truuver \& Meidla, pp. 744, 746, 747.

Lectotype. - External mould of the right valve, no. L02909t, Department of Historical Geology \& Palaeontology, Geological Institute, University of Lund; originally figured by Troedsson (1918, fig. 9), refigured by Gailīte (1970, pl. 1, fig. 5); designated by Gailīte (1970).

Paralectotype. - No. L02908t, Department of Historical Geology \& Palaeontology, Geological Institute, University of Lund.

Type horizon and locality. - Brachiopodskiffer ("Brachiopod Shale" = Dalmanitina Beds), Ashgill, Upper Ordovician. Röstånga, Scania, Sweden.

Material. -8 specimens on rock slabs, mostly internal moulds. Three of them described by Schallreuter \& Krůta (1990) are deposited in the Prague National Museum under different collection numbers than was presented in the paperspecimen NM L 38872a (now NM L 29062a), NM L 38872b (now NM L 29062b) and NM L 38873 (now NM L 29061).

Description. - The valves are of small size and moderately long. The outline is rather amplete and rectangular in the lateral view. The dorsal margin is almost as long as the whole length of the carapace and seems to be somewhat wavy in specimens that are not partially covered by rock. The cardinal angles are obtuse with the anterior one bigger than posterior one. The anterior end is more rounded than the posterior one. There are two distinct rounded nodes in the dorsocentral area separated by narrow sulcal depression. The posterodorsal node is oblong and larger than the anterodorsal node. Ventrally of the nodes there is a ridgelike lobe running along the ventral margin and terminating under the posterodorsal node. Another ridge-like and rounded adventral elevation follows the entire free margin and is separated from the lateral surface by an inner parallel furrow. The lateral surface is smooth. 
Table 6. Scanipisthia rectangularis (Troedsson, 1918), dimensions $(\mathrm{mm})$ and proportions of figured specimens.

\begin{tabular}{lccccc}
\hline Specimen & Valve & Figure & L & H & L:H \\
\hline NM L 29061 & LV & 7E & 0.63 & 0.37 & 1.70 \\
NM L 29062 & LV & 7F & 0.68 & 0.39 & 1.74 \\
CGS KL 162 & LV & 7D & 0.81 & 0.45 & 1.80 \\
\hline
\end{tabular}

Discussion. - Troedsson (1918) described the type species as inequivalved with the left valve being larger than the right one and sometimes overlapping the edge of the right on all sides. The specimens from our collection are represented mainly by internal moulds without any articulated carapaces, therefore the aforementioned overlap cannot be observed. Sexual dimorphism was not observed in our collection. Schallreuter \& Kruita (1990) assigned the genus Scanipisthia with uncertainty to Lomatopisthiidae because of their lack of domiciliar dimorphism typical for this particular family. The authors of the recent study agree with including Scanipisthia into the Bollidae family as it was presented by Gailite (1970).

Occurrence. - The Prague Basin, interval below the Perník Bed: Praha-Nusle - Jezerka and Praha-Radotín - highway tunnel; interval above the Perník Bed, Metabolograptus ojsuensis Zone: two specimens probably belonging to this species were found at Zadní Třebaň - railway cut. (Note that coordinates of Praha-Nusle - Jezerka in Schallreuter \& Krůta 1990 are incorrect). Scanipisthia rectangularis is known also from the Upper Ordovician of Estonia, Lithuania, Latvia, Sweden, north-western Poland and the Carnic Alps.

\section{Genus Warthinia Spivey, 1939}

Type species. - Primitia nodosa Ulrich, 1890; Late Ordovician, Ohio, USA.

\section{Warthinia trinoda sp. nov.}

Figures 5G, H, 8F, G; Table 7

Holotype. - Isolated carapace, FSCU 260 (Fig. 5G).

Paratype. - Isolated carapace (internal mould), CGS KL 140 (Fig. 5H).

Type horizon and locality. - Králův Dvůr Formation, below the Perník Bed interval; Králodvorian, upper Katian. Ořech borehole at the northern edge of the village, Czech Republic; Prague Basin.

Material. - One complete isolated carapace (holotype), 1 isolated carapace (internal mould), 18 internal and external moulds on rock slabs.

Etymology. - After the typical number of nodes.
Diagnosis. - Small, semi-circular valves with three distinct nodes of nearly similar size, posterodorsal one pointed in dorsal part. Dorsal margin straight. Pseudovelum entire and well developed. Surface reticulate except for nodes, pseudovelum and marginal surface.

Description. - The valves are small sized (up to $0.6 \mathrm{~mm}$ long) and rather high. The lateral outline is amplete to slightly postplete. The dorsal margin is straight, approximately 70 percent of the greatest length. Cardinal angles are obtuse, with the posterior one bigger than the anterior one; the dorsum is orthocline. Three rounded nodes on the lateral surface are present, two are along the hinge line, posteriorly inclined and project slightly beyond the dorsum. The posterodorsal node is larger than the anterodorsal and is slightly pointed in its dorsal part. The anteroventral node is slightly smaller than the anterodorsal one. The nodes are ventrally connected by a gently elevated lobe. The adductorial sulcus $\mathrm{S}_{2}$ located between two dorsal nodes is short and moderately deep. The narrow admarginal ridge (= pseudovelum) is developed and parallel to the marginal rim around the entire free margin. The pseudovelum and marginal rim merge at the both cardinal corners. The subvelar field is relatively high, about $0.08 \mathrm{~mm}$ in the ventral part of the holotype. The lateral surface shows conspicuous reticulation except for the nodes and pseudovelum. The distinct features of a valve except for the reticulation are internally reflected on the internal mould.

Table 7. Warthinia trinoda sp. nov., dimensions ( $\mathrm{mm}$ ) and proportions of figured specimens.

\begin{tabular}{lccccc}
\hline Specimen & Valve & Figure & $\mathrm{L}_{\mathrm{D}}$ & $\mathrm{H}_{\mathrm{D}}$ & $\mathrm{L}_{\mathrm{D}}: \mathrm{H}_{\mathrm{D}}$ \\
\hline FSCU 260 holotype & $\mathrm{RV}$ & $5 \mathrm{G}$ & 0.53 & 0.35 & 1.51 \\
CGS KL 140 paratype & $\mathrm{LV}$ & $5 \mathrm{H}$ & 0.49 & 0.28 & 1.75 \\
CGS SZ 64 & $\mathrm{LV}$ & $8 \mathrm{~F}$ & 0.54 & 0.34 & 1.59 \\
\hline
\end{tabular}

Discussion. - Warthinia trinoda sp. nov. shows a close relationship to Warthinia paupera Schmidt, 1941 from the underlying Bohdalec Formation (see more in Prribyl, 1979). The species was originally described as Ulrichia nodosa paupera by Schmidt (1941), who erected the new subspecies of Ulrichia nodosa (Ulrich, 1890) from the Upper Ordovician of Ohio. However, based on several differences in morphology, Warshauer \& Berdan (1982) assigned the North American material to the genus Warthinia Spivey, 1939. We found our material corresponding to this assignment at the generic level. Warthinia trinoda differs from the American $W$. nodosa in its smaller posterodorsal and anteroventral node, the lack of canaliculus between the velar ridge and marginal rim, and in the absence of reticulation on nodes, pseudovelum and marginal surface. All the specimens of $W$. trinoda possess only three nodes, whereas $W$. nodosa includes quadrinodose valves as well. Warshauer \& Berdan (1982) explained this variation in the number of nodes to be 
induced by ecologic mechanisms (e.g. reduction in salinity) and did not consider the different number of nodes as a character of species. Warthinia trinoda resembles Warthinia paupera Schmidt, 1941 from the Bohdalec Formation, but differs in having a shorter hinge line, more rounded cardinal angles, a smaller posterodorsal node and higher position of anteroventral node, which is also much closer to the anterodorsal node. The pseudovelum is wider and partly reticulated in $W$. paupera. Schallreuter \& Krůta (2001b) mentioned the occurrence of another Warthinia species from the Letná Formation of the Prague Basin, namely Warthinia paupa that is considered a synonym of Warthinia paupera by Schallreuter \& Hinz-Schallreuter (1998). This species differs from $W$. trinoda in having a bulge-like pseudovelum which broadened dorsally, a comparatively larger and more elongated posterodorsal node directed posteriorly and an anterodorsal node not projecting over the hinge line. Warthinia saccula (Burr \& Swain, 1965) from the Upper Ordovician of Iowa shows similar features to $W$. trinoda, but the Bohemian specimens lacks coarsely reticulated surface on nodes and pseudovelum. Posterodorsal and anteroventral nodes are distinctly greater, elliptical and do not exceed the hinge line in $W$. saccula.

Occurrence. - Interval below the Perník Bed: Lejškov near Málkov, Levín - slope above the highway, Ořech borehole at the northern edge of the village (depth $7 \mathrm{~m}$ ), Praha-Radotín - highway tunnel.

\section{Genus Parenthatia Kay, 1940}

Type species. - Moorea punctata Ulrich, 1894; Late Ordovician, Minnesota, USA.

\section{Parenthatia hanamiloslavensis sp. nov.}

Figure 8D, E, Table 8

Holotype. - Supposed left valve on a slab, CGS SZ 52 (Fig. 8D).

Paratype. - Supposed left valve on a slab, CGS SZ 206 (Fig. 8E).

Type horizon and locality. - Králův Dvůr Formation, below the Perník Bed interval; Dicellograptus laticeps Zone;
Králodvorian, upper Katian. Levín - slope above the highway, Czech Republic; Prague Basin.

Material. - More than 50 valves, mostly silicified valves on rock slabs and 1 isolated incomplete internal mould.

Etymology. - After beloved parents of the senior author: Hana and Miloslav.

Diagnosis. - Valves of medium size, subovate, non-sulcate with pseudovelum surrounding entire lateral surface of valve. Lateral surface flat and punctate.

Description. - The valves are medium sized (up to $1.5 \mathrm{~mm}$ long), subovate and high. The outline is amplete. The greatest length is located slightly above the mid-height. Due to the lack of any complete isolated valve, knowledge of the hinge line remains unknown. The narrow peripheral ridge (= pseudovelum) is developed along the entire valve and is of the same width. The lateral surface surrounded by the ridge is relatively flat to slightly concave and coarsely punctate.

Table 8. Parenthatia hanamiloslavensis sp. nov., dimensions ( $\mathrm{mm})$ and proportions of figured specimens.

\begin{tabular}{lccccc}
\hline Specimen & Valve & Figure & L & H & L:H \\
\hline CGS SZ 52 holotype & ? LV & $8 \mathrm{D}$ & 0.79 & 0.53 & 1.49 \\
CGS SZ 206 paratype & ? LV & $8 \mathrm{E}$ & 0.98 & 0.65 & 1.50 \\
\hline
\end{tabular}

Discussion. - Parenthatia hanamiloslavensis sp. nov. differs from the type species $P$. punctata (Ulrich, 1894) from the Late Ordovician of Minnesota in less prominent and narrower pseudovelum with the variable marginal surface from flat to slightly convex, which is in contrary distinctly concave in $P$. punctata. P. sadievillensis Warshauer \& Berdan, 1982 is characterised by its strongly defined pseudovelum and especially by an elongate central swelling with no punctuation. Parenthatia hanamiloslavensis resembles mostly $P$. reticulata Blumenstengel, 1965 by the similar size of the valves and less prominent pseudovelum, but $P$. reticulata differs in possessing a straight dorsal margin and distinct cardinal angles.

Occurrence. - Interval below the Perník Bed: Králův Dvůr,

Figure 6. A, B - Euprimites (Euprimites) kralodvorensis sp. nov.; A - CGS KL 144 (holotype), partly exfoliated left valve, lateral view; $\mathrm{A}_{1}-$ ventral view; $\mathrm{A}_{2}$ - anterolateral view; $\mathrm{A}_{3}$ - posterolateral view; B - CGS KL 154 (paratype), partly exfoliated right valve, lateral view; $\mathrm{B}_{1}$ - detail of surface reticulation. - C-E - Sigmobolbina? sp., C - CGS KL 207, incomplete left valve, lateral view; $\mathrm{C}_{1}$ - dorsal view; D - CGS KL 226, incomplete left valve, lateral view; $\mathrm{D}_{1}$ - dorsal view; E - CGS KL 161a, incomplete right valve; $\mathrm{E}_{1}$ - detail of surface reticulation. $\bullet \mathrm{F}-\mathrm{H}-$ Platybolbina runica Schallreuter \& Krůta, 1984; F - NM L 22740 (holotype), incomplete left heteromorphic valve with remains of silicified shell, lateral view; G - NM L 22741 (paratype), internal mould of the right valve, lateral view; H - NM L 22742 (paratype), counterpart of the specimen NM L 22741 with remains of silicified shell, lateral view. Localities: Praha-Radotín - highway tunnel (A, B, E); Zadní Třebaň - railway cut (interval above the Perník Bed) (C, D); Praha-Nusle Jezerka $(\mathrm{F}-\mathrm{H})$. SEM photomicrographs $\left(\mathrm{A}_{1}-\mathrm{A}_{3}, \mathrm{C}_{1}, \mathrm{~F}-\mathrm{H}\right)$. All scale bars $500 \mu \mathrm{m}$. 


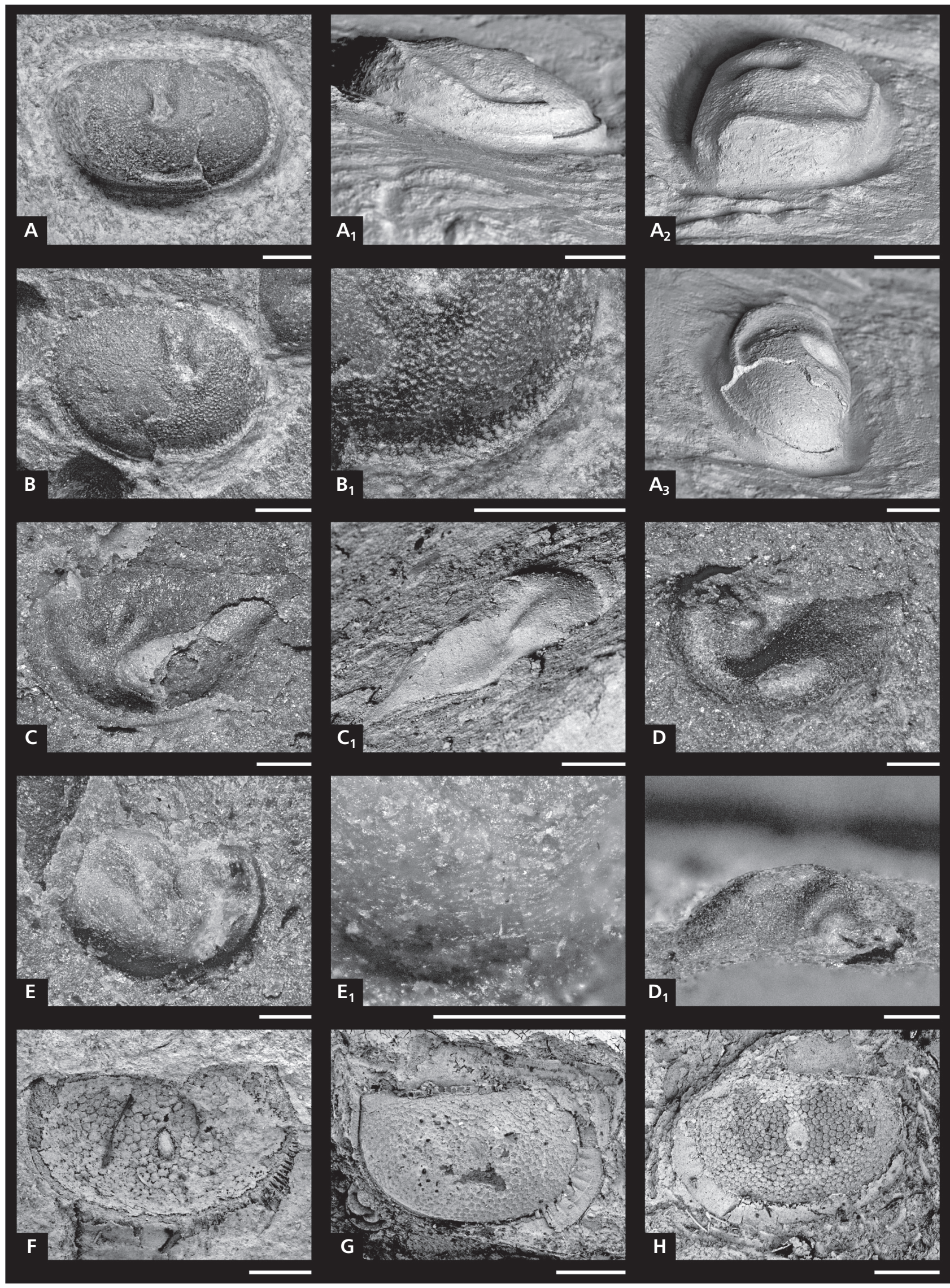


Levín - slope above the highway, Praha-Radotín - highway tunnel. Very abundant at two latter localities.

Superfamily Aechminacea Bouček, 1936

Family Aechminidae Bouček, 1936

\section{Genus Aechmina Jones \& Holl, 1869}

Type species. - Aechmina cuspidata Jones \& Holl, 1869; Silurian, Wenlock, England.

\section{Aechmina sp.}

Figure $7 \mathrm{H}$, Table 9

Material. - Only one internal mould on a rock slab.

Description - The available specimen is very small sized (excluding spine), amplete and elongated. Cardinal corners are not clearly observable. Backward directed prominent spine in the centrodorsal part of the valve, divided by a shallow furrow along its entire length running in the middle part of the spine. The valve is gently convex with a smooth surface without any additional structures.

Table 9. Aechmina sp., dimensions (mm) and proportions of figured specimen.

\begin{tabular}{lccccr}
\hline Specimen & Valve & Figure & L & H & $\mathrm{H}_{\mathrm{S}}$ \\
\hline CGS KL 170b & LV & $7 \mathrm{H}$ & 0.67 & 0.33 & $>0.60$ \\
\hline
\end{tabular}

Discussion. - The internal mould possesses some of the characters of Aechmina species including prominent centrodorsally located spine, an elongated outline and straight dorsal margin. The studied specimen is therefore assigned to this genus. Aechmina sp. differs from the other similar species of the genus in the relatively shorter spine with the dividing furrow. It is likely a preadult specimen.

Occurrence. - Interval below the Perník Bed, Dicellograptus laticeps Zone: Levín - slope above the highway.

\section{Aechmina? meidlai sp. nov.}

Figure 3E, Table 10
Holotype. - Isolated incomplete left valve, CGS KL 63 (Fig. 3E).

Type horizon and locality. - Králi̊v Dvůr Formation, the Perník Bed interval; uppermost Králodvorian, topmost Katian. Zadní Třebaň - railway cut, Czech Republic; Prague Basin.

Material. - The holotype and 3 fragments.

Etymology. - In honour of Prof. Tõnu Meidla (University of Tartu, Estonia), the distinguished ostracod specialist.

Diagnosis. - Small and nearly ovate valves with posterolaterally curved spine. Dorsal margin straight, cardinal angles obtuse. Lateroventral bend along free margin. Lateral surface punctate.

Description. - The valve is small, rather ovate, preplete with a very high shape. The dorsal margin is straight. A prominent, posterolaterally curved and partly destroyed (during preparation) spine is situated in the antero- to partly centrodorsal part of the valve and is not projecting beyond the dorsal margin. Between the spine and lateral surface, there is a faint depression, deepest posteroventrally. The valve is highly convex with a relatively flat lateral surface and wide marginal surface with a distinct bend between them. The marginal surface exhibits a slightly concave character and is visibly smooth. The lateral surface is coarsely punctate except for the spine and lateroventral bend.

Table 10. Aechmina? meidlai sp. nov., dimensions (mm) and proportions of figured specimen.

\begin{tabular}{lccccc}
\hline Specimen & Valve & Figure & L & H & L:H \\
\hline CGS KL 63 holotype & LV & 3E & 1.00 & 0.73 & 1.37 \\
\hline
\end{tabular}

Discussion. - Aechmina? meidlai sp. nov. exhibits the general features of the genus (e.g. ovate outline, dorsal posterolaterally curved spine), but differs in the presence of a lateroventral bend and distinct punctuation of the lateral surface that is not usual among previously described Aechmina species. Aechmina maccormicki Copeland, 1973 from the Upper Ordovician of Canada and northern England

Figure 7. A - Ningulella? sp., CGS PB 1202, incomplete left valve, lateral view. • B - Leperditella? sp. A; CGS KL 167, incomplete right valve, lateral view. $\bullet$ C - Longiscula cf. perfecta Meidla, 1993, CGS KL 161b, partly exfoliated left? valve, lateral view. $・$ D-F - Scanipisthia rectangularis (Troedsson, 1918); D - CGS KL 162, partly covered left valve, lateral view; E - NM L 29061, partly covered left valve (internal mould), lateral view; F - NM L 29062, left valve (internal mould), lateral view. $・ \mathrm{G}$ - Crescentilla laciniata sp. nov., left specimen is internal mould of the right valve of the holotype CGS KL 179a, right specimen is internal mould of the left valve of the paratype CGS KL 179b; $\mathrm{G}_{1}$ - holotype, lateroventral view; $\mathrm{G}_{2}$ - holotype, laterodorsal view. $\bullet \mathrm{H}$ - Aechmina sp., CGS KL 170b, internal mould of the left valve, lateral view; $\mathrm{H}_{1}-$ laterodorsal view. $・ \mathrm{I}-$ "Beyrichia" barbara Barrande, 1872, NM L 8853 (holotype), internal mould, lateral view. • J, K - Cytherellina? fugax (Barrande, 1872); J - NM L 8854 (lectotype), internal mould of the right valve, lateral view; K - NM L 8855 (paralectotype), internal mould of the right valve, lateral view. • L - "Entomozoe" rara (Barrande, 1872): NM L 8843 (holotype), internal mould of the left valve, lateral view. Localities: Lejškov near Málkov (A); Praha-Radotín - highway tunnel (B-D); Praha-Nusle - Jezerka (E, F); Praha-Velká Chuchle - slope above the hippodrome (G); Levín - slope above the highway (H); Králův Dvůr (I-K); Lejškov near Málkov (L). SEM photomicrographs (E-H). Scale bars $500 \mu \mathrm{m}\left(\mathrm{A}-\mathrm{D}, \mathrm{G}_{1} \mathrm{G}_{1}, \mathrm{I}-\mathrm{L}\right), 300 \mu \mathrm{m}(\mathrm{E}, \mathrm{F}), 200 \mu \mathrm{m}\left(\mathrm{G}_{2}\right)$ and $100 \mu \mathrm{m}(\mathrm{H}, \mathrm{H1})$. 


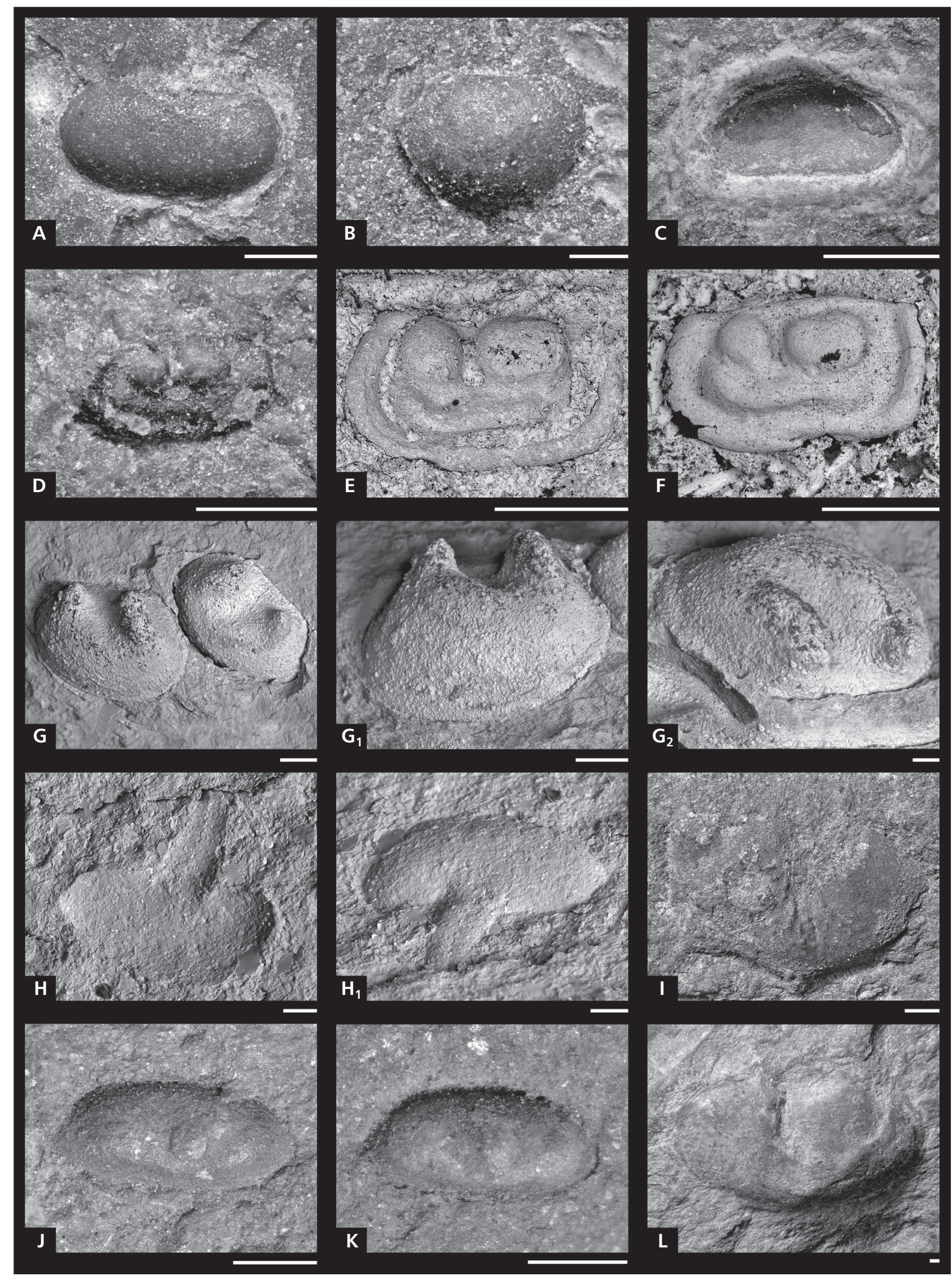


seems to be very close, but the lateroventral area is not so steep and the lateral surface lacks any sign of punctuation.

Occurrence. - The Perník Bed: Zadní Třebaň - railway cut.

\section{Genus Crescentilla Barrande, 1872}

Type species. - Crescentilla pugnax Barrande, 1872; Late Ordovician, Czech Republic.

\section{Crescentilla laciniata sp. nov.}

Figure 7G, Table 11

Holotype. - Internal mould of the right valve, CGS KL 179a (Fig. 7G, left specimen), $\mathrm{G}_{1}, \mathrm{G}_{2}$.

Paratype. - Internal mould of the left valve, CGS KL 179b (Fig. 7G, right specimen).

Type horizon and locality. - Králův Dvưr Formation, upper part, below the Perník Bed interval; Dicellograptus laticeps Zone; upper Králodvorian, upper Katian. Praha-Velká Chuchle slope above the hippodrome, Czech Republic; Prague Basin.

Material. - Two internal moulds on a rock slab.

Etymology. - From Latin laciniata (= horned), referring to the horn-like projection of the lobes.

Diagnosis. - Valves large, nearly preplete and very high in shape. Two prominent and rounded lobes with no projection over dorsal margin. Free margin simply arched.

Description. - Valves are high to very high, large and preplete in lateral view. The valves are strongly convex and possess two prominent backward directed and ventrocentrally connected lobes $\mathrm{L}_{2}$ and $\mathrm{L}_{3}$, not overreaching relatively short dorsal margin of the valve. $\mathrm{L}_{2}$ is slightly longer and wider than $\mathrm{L}_{3}$. The forward directed $\mathrm{S}_{2}$ is broad. The ventral margin is regularly arched. There are no visible impressions on lateral surfaces of the internal moulds.

Discussion. - Crescentilla laciniata sp. nov. differs from other previously described representatives from the
Table 11. Crescentilla laciniata $\mathrm{sp}$. nov., dimensions ( $\mathrm{mm}$ ) and proportions of figured specimens.

\begin{tabular}{lccccc}
\hline Specimen & Valve & Figure & L & H & L:H \\
\hline CGS KL 179a holotype & RV & 7G (left), $\mathrm{G}_{1}, \mathrm{G}_{2}$ & 2.27 & 1.62 & 1.40 \\
CGS KL 179b paratype & LV & $7 \mathrm{G}$ (right) & 2.19 & 1.40 & 1.56 \\
\hline
\end{tabular}

underlying formations of the Prague Basin (e.g. C. vaneki Přibyl, 1979; C. pugnax Barrande, 1872) by having rounded and much shorter lobes without any dorsal overlap and less circular outline. C. pugnax was originally designated by Barrande (1872). Its occurrence, besides other formations of the Prague Basin, was also reported from the Králův Dvůr Formation. However, Prribyl (1979) assigned part of the Barrande's material, including specimens from the Králův Dvůr Formation, to $C$. vaneki. Unfortunately, no evidence of these was found in any collection. C. baltica Neckaja, 1966 from the Upper Ordovician of Estonia and Finland shows a more bulb-like lobe and centrally directed lobes with $\mathrm{L}_{3}$ overreaching dorsal margin.

Occurrence. - Interval below the Perník Bed, Dicellograptus laticeps Zone: Praha-Velká Chuchle - slope above the hippodrome. The sample with holotype was collected at the outcrop of the GPS coordinates: $50^{\circ} 0^{\prime} 14.976^{\prime \prime} \mathrm{N}$, $14^{\circ} 22^{\prime} 55.992^{\prime \prime} \mathrm{E}$.

\section{Genus Pseudulrichia Schmidt, 1941}

Type species. - Leperditia bivertex Ulrich, 1879; Late Ordovician, Kentucky, USA.

\section{Pseudulrichia lucberkensis sp. nov.}

Figure $8 \mathrm{~A}-\mathrm{C}$, Table 12

Holotype. - Internal mould of supposed left valve on a rock slab, CGS KL 170a (Fig. 8A).

Type horizon and locality. - Králův Dvůr Formation, below the Perník Bed interval; Dicellograptus laticeps Zone; Králodvorian, upper Katian. Levín - slope above the highway, Czech Republic; Prague Basin.

Material. -6 internal moulds on rock slabs and 2 fragments.

Figure 8. A-C - Pseudulrichia lucberkensis sp. nov.; A - CGS KL 170a (holotype), internal mould of the left? valve, lateral view; B - CGS KL 171, internal mould of the left? valve, lateral view; C - CGS KL 176, incomplete right? valve, lateroventral view. $\bullet$ D, E - Parenthatia hanamiloslavensis sp. nov.; D - CGS SZ 52 (holotype), left? valve, lateral view; $D_{1}$ - detail of surface punctuation; E - CGS SZ 206 (paratype), left? valve, lateroventral view. F, G - Warthinia trinoda sp. nov.; F - CGS SZ 64, partly covered left valve, lateroventral view; G - CGS SZ 63, external mould, detail of surface punctuation. $\bullet \mathrm{H}$ - Aviacypris? sp., CGS KL 163, right valve, lateral view. $・$ I-L - Parapyxionella prunella (Barrande, 1872); I - NM L 8848 (lectotype), left valve, lateral view; $\mathrm{I}_{1}$ - dorsal view; J - CGS KL 206, right valve, lateral view; K - NM L 9572, left valve with remains of surface punctuation, lateral view; $\mathrm{K}_{1}$ - detail of surface punctuation; L - CGS SZ 14, partly exfoliated left valve, lateral view. Localities: Levín - slope above the highway (A-G, L); Praha-Radotín - highway tunnel (H); Kosov (I, K); Zadní Třebaň - railway cut (interval above the Perník Bed) (J). SEM photomicrographs (A-G, I $I_{1}$, $\left.\mathrm{K}, \mathrm{K}_{1}\right)$. Scale bars $500 \mu \mathrm{m}(\mathrm{H}-\mathrm{L}), 200 \mu \mathrm{m}(\mathrm{D}, \mathrm{E}), 100 \mu \mathrm{m}(\mathrm{A}-\mathrm{C}, \mathrm{F})$ and $50 \mu \mathrm{m}\left(\mathrm{D}_{1}, \mathrm{G}\right)$. 


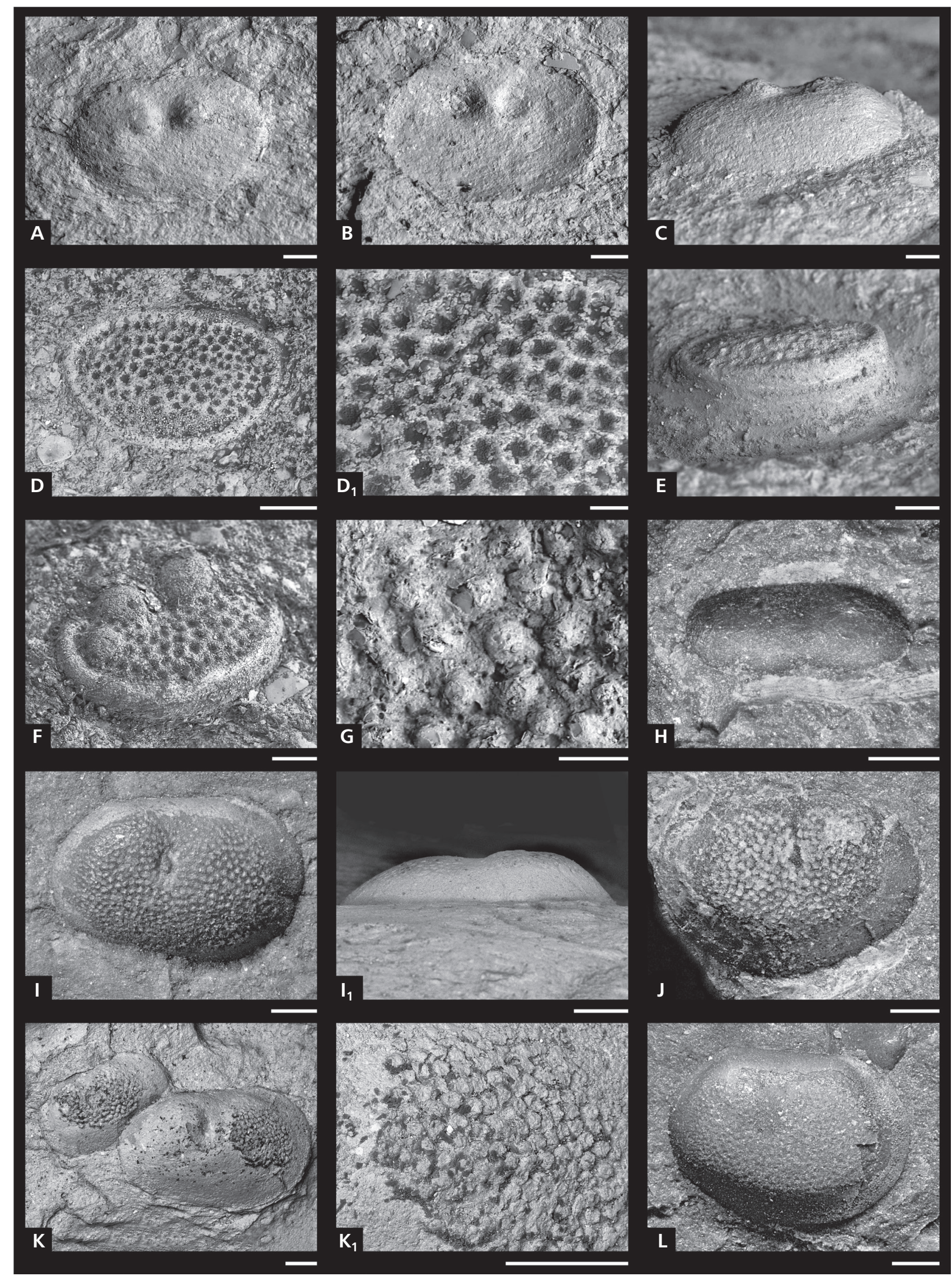


Etymology. - After the historical name of the type locality: Lucberk, the Czech form of the original name Luc Berg in German.

Diagnosis. - Valves small, elongate, outline amplete. Two small, almost equally sized, rounded and dorsocentrally situated nodes. No distinct sulcus between nodes. Lateral surface smooth.

Description. - Valves are small-sized (up to $0.8 \mathrm{~mm}$ long), high and nearly amplete. The maximum length is situated at the mid-height of the valve. The dorsal margin is straight and relatively short (e.g. $0.37 \mathrm{~mm}$ out of $0.61 \mathrm{~mm}$ in the holotype). No distinct dorsum is developed. Cardinal angles are obtuse. The carapace is moderately convex and possesses two small obtusely rounded nodes of nearly equal size situated in the dorsocentral area of the valve. The lateral surface is smooth, with no distinct sulcus developed between the nodes.

Table 12. Pseudulrichia lucberkensis sp. nov., dimensions (mm) and proportions of figured specimens.

\begin{tabular}{lccccc}
\hline Specimen & Valve & Figure & L & H & L:H \\
\hline CGS KL 170a holotype & ? LV & 8A & 0.61 & 0.41 & 1.49 \\
CGS KL 171 & ? LV & 8B & 0.62 & 0.44 & 1.41 \\
CGS KL 176 & ? RV & 8C & 0.79 & 0.56 & 1.41 \\
\hline
\end{tabular}

Discussion. - Specimens of Pseudulrichia lucberkensis sp. nov. agree well with the type species $P$. bivertex from the Upper Ordovician of Kentucky (Ulrich 1879). Nevertheless, the American species has anteriorly and more dorsally located nodes of unequal size and strongly convex carapace possessing deep sulcus. Pseudulrichia disputabile Sidaravičiene, 1975 from Baltica has mainly larger spine-like nodes pointing antero- and posterodorsally, with a distinct sulcus in between. Pseudulrichia lucberkensis in comparison with P. inarguta (Neckaja 1966) lacks the specific oblong posterior node and has less elongated outline. From the other previously described species of Pseudulrichia from underlying formations of the Prague Basin [e.g. P. perforata (Barrande, 1872) and P. pseudobivertex Přibyl, 1979] $P$. lucberkensis sp. nov. differs in the relatively smaller size of the valves, more elongated outline and in the equal size of the dorsocentrally situated nodes.

Occurrence. - Interval below the Perník Bed: Levín - slope above the highway and Praha-Nusle - Jezerka; the Perník Bed: two poorly preserved fragments tentatively assigned to the species from Zadní Třebaň - railway cut.

\section{Pseudulrichia risumata sp. nov.}

\section{Figure 5I-K, Table 13}

Holotype. - Isolated carapace (internal mould), FSCU 279 (Fig. 5I).
Paratypes. - Isolated carapaces (internal mould), FSCU 271 (Fig. 5K) and FSCU 274 (Fig. 5J).

Type horizon and locality. - Králův Dvůr Formation, below the Perník Bed interval; Králodvorian, upper Katian. Ořech borehole at the northern edge of the village, Czech Republic; Prague Basin.

Material. - 15 isolated specimens, from which only 4 complete carapaces.

Etymology. - From Latin risum (= smile, laugh); referring to the look of the lateral surface.

Diagnosis. - Valves small, elliptical, outline amplete. Two relatively large, dorsocentrally to centrally situated spines. Posterior spine bigger than anterior spine. Lateral surface smooth.

Description. - Valves are small (up to $0.65 \mathrm{~mm}$ long), very high, with an amplete and elliptical outline. The dorsal margin is straight and short, no distinct dorsum is developed. The cardinal angles are obtuse. There are two prominent spines dorsocentrally to centrally situated on the lateral surface. The posterior spine is larger and more pointed than the anterior spine and posteriorly curved, the preadductorial spine is directed anteriorly. A deep and short $\mathrm{S}_{2}$ between the spines. The carapace is strongly convex with the posterior part more inflated than the anterior one. A ventral lobe is developed in the ventrocentral area. The lateral surface is smooth.

Table 13. Pseudulrichia risumata sp. nov., dimensions (mm) and proportions of figured specimens.

\begin{tabular}{lccccc}
\hline Specimen & Valve & Figure & L & H & L:H \\
\hline FSCU 279 holotype & LV & 5I & 0.59 & 0.44 & 1.34 \\
FSCU 271 paratype & LV & 5K & 0.57 & 0.40 & 1.43 \\
FSCU 274 paratype & LV & 5J & 0.59 & 0.45 & 1.31 \\
\hline
\end{tabular}

Discussion. - Pseudulrichia risumata sp. nov. possesses similar features as $P$. norvegica Henningsmoen, 1954 from the Upper Ordovician of Norway, but the same curved spines common in both species are much larger and significant in the Scandinavian species. The new species shares distinct spine-like nodes with Baltic P. disputabile Sidaravičiene, 1975 , but they are smaller and more centrally situated in P. risumata, which also features a more elliptical outline than $P$. disputabile. Pseudulrichia risumata resembles P. pseudobivertex Prribyl, 1979 from the underlying Bohdalec Formation, but differs in having a more elongated outline, a distinct ventral lobe and more prominent and pointed spines situated in the central area of the valve instead of anterodorsally like in P. pseudobivertex. Pseudulrichia 
risumata differs from $P$. lucberkensis, described from the same formation, in having spine-like and larger nodes and in its stronger convexity.

Occurrence. - Interval below the Perník Bed: Ořech borehole at the northern edge of the village (depth $7 \mathrm{~m}$ ).

Family Spinigeritidae Schallreuter, 1980

\section{Genus Spinigerites Schallreuter, 1980}

Type species. - Primitiella? spiniger Lindström, 1953; Late Ordovician, Sweden.

\section{Spinigerites ostrovites sp. nov.}

Figure 3H, I; Table 14

Holotype. - Isolated incomplete heteromorphic left valve, CGS KL 64 (Fig. 3H).

Paratype. - Isolated incomplete left valve, CGS KL 66 (Fig. 3I).

Type horizon and locality. - Králův Dvưr Formation, the Perník Bed interval; uppermost Králodvorian, topmost Katian. Zadní Třebaň - railway cut, Czech Republic; Prague Basin.

Material. - 3 internal moulds on rock slabs, 4 more or less incomplete isolated valves and 5 fragments.

Etymology. - After the senior author's hometown - Ostrov.

Diagnosis. - Valves of medium size, elongated, amplete to slightly postplete outline. Moderately convex, uni-sulcate. Very pronounced $\mathrm{N}_{2}$ and posteroventral spine overreaching the posterior margin. Surface smooth.

Description. - The valves are medium-sized (up to $1.56 \mathrm{~mm}$ ), elongated and of amplete outline. The dorsal margin is straight and very long. The distinct and rounded preadductorial node is developed just above the mid-height area. Directly behind there is a relatively deep $\mathrm{S}_{2}$ running towards the dorsal margin. The small posteriorly directed spine in the posteroventral area of the valve, but is usually missing or indistinct as a result of the preparation and cleaning process of the specimens although still clearly defined on the internal moulds. The lateral surface is smooth.

Discussion. - Spinigerites ostrovites sp. nov. differs from the type species S. spiniger (Lindström, 1953) from the Late Ordovician of Sweden mainly by having a very significant preadductorial node accompanied by a deep sulcal depression. The spine in $S$. ostrovites is longer (considering the
Table 14. Spinigerites ostrovites sp. nov., dimensions ( $\mathrm{mm}$ ) and proportions of figured specimens.

\begin{tabular}{lccccc}
\hline Specimen & Valve & Figure & L & H & L:H \\
\hline CGS KL 64 holotype & LV & 3H & 1.56 & 0.80 & 1.95 \\
CGS KL 66 paratype & LV & 3I & 1.13 & 0.61 & 1.85 \\
\hline
\end{tabular}

spine before it fell apart) and has a different position closer to the posteroventral part of the valve. S. bellevuensis Schallreuter, 1980 from the Upper Ordovician of Iowa, in comparison with $S$. ostrovites exhibits a punctate surface, a less pronounced node and a short mid-posteriorly located spine. According to Schallreuter (1980), sexual dimorphism could be observed in this genus. The heteromorphic valves are characterised by a more amplete and less postplete outline, elongated shape, longer valves and more flattened surface. With regard to this, there is an absolute prevalence of heteromorphs in our material.

Occurrence. - Interval below the Perník Bed, Dicellograptus laticeps Zone: Levín - slope above the highway; the Perník Bed and interval above the Perník Bed, Metabolograptus ojsuensis Zone: Zadní Třebaň - railway cut.

\section{Spinigerites sp.}

Figure 3J, Table 15

Material. -3 more or less incomplete isolated valves.

Description. - The valves are medium-sized (up to $1.45 \mathrm{~mm}$ ), long, elongated and of amplete outline. The dorsal margin is straight and long, but shorter than the maximum length, which is around the mid-height of the valve. The moderately convex carapace lacks any evidence of sulcate depression or nodes. Only a short, but distinct posteriorly directed spine is present on the posteroventral part of the valve near the mid-height, slightly exceeding the free margin from the lateral view. The lateral surface is smooth.

Table 15. Spinigerites sp., dimensions ( $\mathrm{mm})$ and proportions of figured specimen.

\begin{tabular}{lccccc}
\hline Specimen & Valve & Figure & L & H & L:H \\
\hline CGS KL 74 & LV & 3J & 0.97 & 0.48 & 2.02 \\
\hline
\end{tabular}

Discussion. - Spinigerites sp. differs from the type species S. spiniger (Lindström, 1953) in the absence of any distinctive sulcal depression or node, in its more elongated shape and amplete outline, even in comparison with the heteromorphs in S. spiniger, and in its stronger convexity. The less elevated spine is situated closer to the ventral margin and is slightly overreaching it in Spinigerites sp. The Upper Ordovician species S. hadros Jones, 1987 from Britain shares a similar simple morphology and larger size, but differs in 
significant postplete outline, even in heteromorphs and in a less elevated spine not overreaching the posteroventral margin. In comparison to $S$. ostrovites sp. nov. from the same formation in the Prague Basin, Spinigerites sp. lacks the preadductorial node and the posteroventral spine is more posterocentrally situated in $S$. sp. Due to the high resemblance between those two species, $S$. sp. may just be a variation (which is not unusual in this genus) within S. ostrovites, and we cannot rule this option out. On the other hand, specimens of $S$. sp in comparably same size as $S$. ostrovites still lack any evidence of vaulting features (node, sulcus) so we would rather prefer this species division until there is better material available.

Occurrence. - The Perník Bed: Zadní Třebaň - railway cut.

Family Circulinidae Neckaja, 1966

\section{Genus Orechina Krůta, 1968}

Type species. - Orechina punctata Krůta, 1968; Late Ordovician, Czech Republic.

\section{Orechina punctata Krůta, 1968}

1968 Orechina punctata n. sp.; Krůta, pp. 56-60, tab. 1, figs $1-4$, text-figs $1,2$.

1979 Orechina punctata. - Přibyl, p. 89, text-figs 15.6-7.

1980 Orechina punctata Krůta, 1968. - Schallreuter, pp. 16, 17.

1987 Orechina punctata Krůta, 1968. - Schallreuter \& Krůta, pp. 58, 59, fig. 1.1.

1988 Orechina punctata Krůta, 1968. - Schallreuter \& Krůta, p. 104.

2001b O. punctata Krůta, 1968. - Schallreuter \& Krůta, p. 89.

2012 Orechina punctata Krůta, 1968. - Salas \& Vaccari, p. 184.

Holotype. - Right valve, FSCU 286, originally designated and figured by Krůta (1968, tab. 1, figs 1-4). However, we were able to find neither the holotype specimen nor any other specimen from the type series. We traced its last loan and consider the material as lost. We have no other specimen of this species available, thus we are not able to designate the neotype.

Type horizon and locality. - Králův Dvůr Formation, below the Perník Bed interval; Králodvorian, upper Katian. Ořech dug out well at the northern edge of the village, Czech Republic; Prague Basin.

Material. - No specimen available for this study. Krůta (1968) studied 9 well preserved carapaces, 13 valves and several fragments for his original description.
Description and discussion. - See Krůta (1968).

Occurrence. - Interval below the Perník Bed: Ořech - dug out well on the land of the house no. 51 at the northern edge of the village.

\section{Genus Parapyxionella Přibyl, 1979}

Type species. - Primitia prunella Barrande, 1872; Late Ordovician, Czech Republic.

Parapyxionella prunella (Barrande, 1872)

Figures 3G, 8I-L; Table 16

1868 Primitia prunella Barr. - Bigsby, p. 200. [nomen nudum]

? 1868 Primitia gregaria Barr. - Bigsby, p. 200. [nomen nudum]

1869 Primitia prunella, Barrande, MS. - Jones \& Holl, p. 223. [nomen nudum]

? 1869 Primitia gregaria Barrande, MS. - Jones \& Holl, p. 223. [nomen nudum]

partim 1872 Primit. prunella. Barr.; Barrande, p. 550, pl. 26, figs 5a-e, 6a-g.

1934 Primitia prunella Barrande. - Bassler \& Kellett, p. 453.

1954 Primitia prunella Barr. - Hughes, p. 43.

1957 Parapyxion prunellum (Barr.). - Jaanusson, p. 424.

1966 Parapyxion prunellus (Barr.). - Havlíček \& Vaněk, p. 60.

1979 Parapyxionella prunella (Barrande, 1872). - Přibyl, p. 93 , pl. 6, figs 1-7; text-figs 6.1, 15.3 .

1988 Parapyxionella prunella (Barrande, 1872). - Schallreuter \& Krůta, p. 104.

Lectotype. - Left valve, NM L 8848, originally figured by Barrande (1872, pl. 26, figs 6d, e), refigured by Přibyl (1979, pl. 6, figs 2, 6; text-figs 6.1, 15.3) and herein in Fig. 8I; designated by Přibyl (1979).

Type horizon and locality. - Králův Dvůr Formation, below the Perník Bed interval; Králodvorian, upper Katian. Kosov, Czech Republic; Prague Basin.

Material. - More than 200 specimens including external and internal moulds on rock slabs and 14 fragments.

Diagnosis. - Large, high, subovate valves with faint adductorial sulcus $\mathrm{S}_{2}$ with distinct surrounding lobes. Dorsal margin straight. Carapace strongly convex. Surface punctate except for bend-like flattened margin along the margins.

Description. - The strongly convex valves attain a relatively large size, up to $3.45 \mathrm{~mm}$ in adult specimens. The carapace is 
postplete, high and subovate. The dorsal margin is relatively short in relation to the total length of the valve $(1.57 \mathrm{~mm}$ of a total of $2.89 \mathrm{~mm}$ for the lectotype). The cardinal angles are obtuse, with the posterior one bigger than the anterior one; the dorsum is hypocline. The shallow pit-like $\mathrm{S}_{2}$ extends to near the mid-point of the valve and is anteriorly surrounded by a prominent elevation. The anterior margin is more narrowly rounded than the posterior margin. The lateral surface is distinctly punctate except for the bend-like marginal surface along the entire valve that is not only smooth but also distinctly flattened.

Table 16. Parapyxionella prunella (Barrande, 1872), dimensions (mm) and proportions of figured specimens.

\begin{tabular}{lccccc}
\hline Specimen & Valve & Figure & L & H & L:H \\
\hline NM L 8848 lectotype & LV & 8I & 2.89 & 1.87 & 1.54 \\
NM L 9572 & LV & 8K & 3.11 & 1.97 & 1.58 \\
CGS KL 206 & RV & 8J & 2.73 & 2.01 & 1.36 \\
CGS KL 4 & RV & 3G & $>1.31$ & 1.43 & $>0.91$ \\
CGS SZ 14 & LV & 8L & 2.59 & 1.85 & 1.40 \\
\hline
\end{tabular}

Discussion. - Parapyxionella prunella (Barrande, 1872) is similar to Orechina species in its punctate lateral surface set off from the smooth marginal surface. Orechina punctata Krůta, 1968, described from the Králův Dvưr Formation, differs in its elliptical outline, epicline to orthocline dorsum, weakly developed $\mathrm{S}_{2}$ and wider marginal bend that is separated by an edge from its distinctly flat lateral surface. The Baltic species Orechina procera Schallreuter, 1980 possesses a similar outline and its lateral surface is weakly convex, but it differs in broader $\mathrm{S}_{2}$ and strongly pronounced reticulation. Compared to other genera of the family Circulinidae, Parapyxionella possesses mainly both oblong, postplete valves and prominent adductorial sulcus. In contrary, P. prunella shares a punctate lateral surface with Circulinella gailitae Meidla, 1996, but the smooth bend along the margin is narrower in C. gailitae. Some of the representatives of the genus Priminsolenia Meidla, 1996 possess postplete outline and adductorial pit, but they have markedly coarse reticulation on the whole lateral surface of the valve. The examined specimens show variability in the lateral outline. In some specimens, the anterior half is more inflated and free margin more flattened than in other valves. Prribyl (1979) considered this variability a presumable sexual dimorphism.

Occurrence. - Interval below the Perník Bed: Karlík, Kosov, Králův Dvůr, Lejškov near Málkov, Levín - slope above the highway, Praha-Běchovice, Praha-Radotín highway tunnel, Praha-Řeporyje, Praha-Velká Chuchle slope above the hippodrome; the Perník Bed and interval above the Perník Bed: Zadní Třebaň - railway cut. It is the most abundant ostracod species of the Králův Dvůr Formation.

\section{Genus Easchmidtella Schallreuter, 1967}

Type species. - Easchmidtella crassiumbonata Schallreuter, 1967; Late Ordovician, Germany (erratic boulder).

\section{Easchmidtella nuda (Krůta, 1968)}

Figure 5E, F; Table 17

1968 Orechina nuda sp. n.; Krůta, p. 60, pl. 2, figs 1-4; text-fig. 3.

1979 O. nuda. - Přibyl, p. 89.

1980 O. nuda Krůta, 1968. - Schallreuter, p. 17.

1987 O. nuda Krůta, 1968. - Schallreuter \& Krůta, pp. 57, 63.

1987 Easchmidtella nudista nom. nov.; Schallreuter \& Krůta, p. 63.

1988 Easchmidtella nudista Schallreuter \& Krůta, 1987 [ = Orechina nuda Krůta, 1968]. - Schallreuter \& Krůta, p. 104.

Holotype. - Isolated carapace (internal mould), FSCU 302, originally designated and figured by Krůta (1968, pl. 2, figs $1-4)$ and refigured herein in Fig. 5E.

Type horizon and locality. - Králův Dvůr Formation, below the Perník Bed interval; Králodvorian, upper Katian. Ořech dug out well at the northern edge of the village, Czech Republic; Prague Basin.

Material. - 12 complete and 4 incomplete isolated carapaces.

Diagnosis. - Valves small, elliptical and equal, hinge line straight. Cardinal angles indistinct. Circular lateral surface smooth, with the bend edge developed. The outline from the dorsal view is nearly subhexagonal. Adductorial sulcus indistinct or missing.

Description. - The valves are small, extremely high and of elliptical outline. The maximum length up to $0.65 \mathrm{~mm}$, usually at mid-height of the valve. The dorsum is distinctly epicline, lateral surface overreaches the hinge line. The obtuse cardinal angles are indistinct from the lateral view. The sulcus $\mathrm{S}_{2}$ is mostly missing or very faint in some specimens. The outline in the dorsal view is nearly subhexagonal because of the sloping lateromarginal bend along the free margin of the valve. The bend is bounded from the flat to

Table 17. Easchmidtella nuda (Krůta, 1968), dimensions (mm) and proportions of figured specimens.

\begin{tabular}{lccccc}
\hline Specimen & Valve & Figure & L & H & L:H \\
\hline FSCU 302 holotype & ? RV & $5 \mathrm{E}$ & 0.61 & 0.50 & 1.22 \\
FSCU 306 & ? LV & $5 \mathrm{~F}$ & 0.52 & 0.39 & 1.33 \\
\hline
\end{tabular}


a weakly convex elliptical lateral surface by a distinct edge. The whole lateral surface is smooth.

Discussion. - Easchmidtella nuda (Krůta, 1968) was originally described as a species within the genus Orechina along with Orechina punctata (Krůta, 1968) from the same stratigraphic level. Prribyl (1979) considered the possibility that $E$. nuda may be conspecific with $O$. punctata based on a similar diagnosis, with the only main difference in the character of the lateral surface of the valves (punctate, smooth). Schallreuter \& Krůta (1987) pointed out that there is no difference in preservation between those species and that the lateromarginal bend common in both of them is no longer considered the most important feature for Orechina species, unlike the punctuation (e.g. Orechina procera Schallreuter, 1980; Orechina krutai Olempska, 1994). Easchmidtella nuda was therefore assigned to genus Easchmidtella because of its elliptical outline, smooth lateral surface, epicline dorsum and indistinct or missing $\mathrm{S}_{2}$. On the other hand, E. nuda is distinguished from the other Easchmidtella species by the presence of a lateromarginal bend which is still less distinct than in O. punctata and by a valve overlap ( $c f$. Meidla 1996, pp. 91, 92; Schallreuter 1967, p. 626). Schallreuter \& Krůta (1987) proposed the new name E. nudista for the Bohemian species due to presumably taxonomic similarity with the Baltic species Circulinella nuda (Neckaja, 1966), but since the latter species was assigned to the new genus Circulinella by Meidla (1996), therefore there is no need to rename E. nuda.

Occurrence. - Interval below the Perník Bed: Ořech - dug out well on the land of the house no. 51 at the northern edge of the village.

Suborder Leiocopa Schallreuter, 1973

Superfamily Aparchitacea Jones in Chapman, 1901

Family Aparchitidae Jones in Chapman, 1901

\section{Genus Baltonotella Sarv, 1959}

Type species. - Macronotella kuckersiana Bonnema, 1909; Late Ordovician, Estonia.

Baltonotella? admirabilis sp. nov.

Figure 3C, D, Table 18

Holotype. - Left incomplete valve on a rock slab, CGS KL 8 (Fig. 3C).

Paratype. - Incomplete carapace, CGS KL 42 (Fig. 3D).

Type horizon and locality. - Králův Dvůr Formation, the Perník Bed interval; uppermost Králodvorian, topmost Katian. Zadní Třebaň - railway cut, Czech Republic; Prague Basin.
Material. - 9 more or less incomplete valves, isolated carapace (paratype).

Etymology. - From Latin admirabilis (= admirable).

Diagnosis. - Valves medium sized, very high, amplete, subcircular. Admarginal frill with no pillar structures along the entire free margin of the valve. Lateral surface circularly reticulated.

Description. - The valves are medium-sized with a very high shape. The lateral outline is amplete and subcircular. The dorsal margin is straight and relatively short. The cardinal angles are obtuse and equal. The greatest length is at midheight. Very narrow admarginal frill along the entire free margin of the valve. The carapace is moderately convex with the greatest width centrally. The lateral surface is very finely circularly reticulated.

Table 18. Baltonotella? admirabilis sp. nov., dimensions ( $\mathrm{mm})$ and proportions of figured specimens.

\begin{tabular}{lccccc}
\hline Specimen & Valve & Figure & L & H & L:H \\
\hline CGS KL 8 holotype & ? LV & 3C & 1.08 & 0.83 & 1.30 \\
CGS KL 42 paratype & $?$ & 3D & 0.80 & $>0.54$ & $>1.48$ \\
\hline
\end{tabular}

Discussion. - Williams \& Vannier (1995) discussed the problematics in the determination of Aparchitidae species. This ostracod group documented from the Ordovician of North America and Europe represents specimens with typical subcircular, gently convex carapace, common absence of a sulcal depression and the right valve overlap along the free margin. Since we do not have any complete sufficiently preserved carapace in the present material, the overlap cannot be observed. However, B.? admirabilis sp. nov. shares common admarginal structure in the form of a frill on the left valve. This particular feature can be observed in other Ordovician Baltonotella species, e.g. B. strodescreekensis (Kraft, 1962) or B. limbata Sidaravičiene, 1975; however, both of them differ in having so-called "pillar structures" (see more in Schallreuter 1973) in a marginal depression and in having a smoothly punctate lateral surface. B. ledaia Sidaravičiene, 1975, another coeval Baltic species, shares the subcircular outline with B.? admirabilis, but its left valve lacks the admarginal frill and its lateral surface is gently punctate. Leperditella? sp. A, also described from the Králův Dvůr Formation, possesses a similar outline, but $B$.? admirabilis has more circular valves and reticulate surface, which is by contrast smooth in specimens of $L$.? sp. A with silicified surface preserved.

Occurrence. - The Perník Bed: Zadní Třebaň - railway cut.

Suborder Eridostraca Adamczak, 1961 
Family Cryptophyllidae Adamczak, 1961

\section{Genus Cryptophyllus Levinson, 1951}

Type species. - Eridoconcha oboloides Ulrich \& Bassler, 1923; Late Ordovician, Minnesota, USA.

\section{Cryptophyllus sp.}

Figure 5B-D, Table 19

Material. - 10 more or less incomplete valves.

Description. - The valves are small with average length ranging from 0.48 to $0.62 \mathrm{~mm}$ and height from 0.36 to $0.50 \mathrm{~mm}$. Dorsal margin and cardinal corners cannot be observed. Carapace consists of a succession of rounded lamellae with their maximum number of 6 , separated by distinct grooves. The studied specimen CGS KL 84 (Fig. 5D) exhibits a well-developed adductorial sulcus $\mathrm{S}_{2}$ between two significant nodes. The surface is smooth.

Table 19. Cryptophyllus sp., dimensions ( $\mathrm{mm}$ ) and proportions of figured specimens.

\begin{tabular}{lccccr}
\hline Specimen & Valve & Figure & L & H & L:H \\
\hline CGS KL 82 & $?$ & 5B & $>0.58$ & 0.49 & $>1.18$ \\
CGS KL 84 & $?$ & 5D & 0.57 & 0.46 & 1.24 \\
CGS KL 91 & $?$ & 5C & $>0.52$ & 0.50 & $>1.04$ \\
\hline
\end{tabular}

Discussion. - The first Cryptophyllus appeared in the early Late Ordovician, comprising the type species Cryptophyllus oboloides (Ulrich \& Bassler, 1923), the youngest occurrence is dated as the Middle Carboniferous (Cryptophyllus sp., Saravia \& Jones 1999). The number of Cryptophyllus species is nearly 40 . However, the species distinction is still unclear due to the limited number of diagnostic features. The number of preserved lamellae are considered by some authors as an arbitrary or unstable criterium (e.g. Jones 1968, Přibyl 1988, Truuver \& Meidla 2015). The significant median sulcus present in Cryptophyllus sp. is absent or short in C. oboloides and in C. pius Truuver \& Meidla, 2015. In the latter species, the sulcus ends with a star-shaped muscle scar. Cryptophyllus gutta Schallreuter, 1968 bears a posteriorly directed spine in the earliest juvenile stage. The number of preserved lamellae is up to 6 in our material; in $C$. oboloides the recorded number does not exceed 5 layers; in C. pius 3 layers. On the contrary, in C. gutta up to 9 layers are recorded. The highest number of valve layers recognised in Cryptophyllus is 15 (Cryptophyllus sp. of Devonian age; more in Becker \& Bless 1974). Our collection of Cryptophyllus sp. is the oldest record of this genus from the Prague Basin so far. Up until this time the oldest records were C. copelandi and C. butovicensis from the upper Silurian, both described by Prribyl (1988).
Occurrence. - The Perník Bed: Zadní Třebaň - railway cut.

Order Platycopida Sars, 1866

Suborder Cytherelliformes Skogsberg, 1920

Superfamily Leperditellacea Ulrich \& Bassler, 1906

Family Leperditellidae Ulrich \& Bassler, 1906

\section{Genus Leperditella Ulrich, 1894}

Type species. - Leperditella rex Coryell \& Schenck, 1941; Middle Ordovician, Kentucky, USA.

\section{Leperditella? sp. A}

Figures 4B, C, 7B; Table 20

Material. - 6 more or less incomplete carapaces (internal moulds) and 35 specimens on rock slabs, mostly internal moulds, some valves with a silicified surface.

Description. - The valves are of medium size (up to $1.65 \mathrm{~mm}$ ) and very high. The outline is subamplete to slightly postplete. The dorsal margin is straight, cardinal angles are obtuse, the posterior one bigger than the anterior one. The posterior end is more broadly curved than the anterior end. The maximum length is located above the mid-height, the greatest width is in the ventral area and maximum convexity is situated in the posterior area of the carapace. The internal moulds show a slightly bigger size of the valve, which is considered the left one, and distinct groove on both valves along the ventral margin. The hinge line appears to be weakly incised on the internal moulds. Lateral surfaces of both internal moulds and silicified specimens on slabs are smooth.

Table 20. Leperditella? sp. A, dimensions ( $\mathrm{mm})$ and proportions of figured specimens.

\begin{tabular}{lccccc}
\hline Specimen & Valve & Figure & L & H & L:H \\
\hline CGS KL 132 & LV & 4B & 0.85 & 0.63 & 1.35 \\
CGS KL 136 & LV & 4C & 0.52 & 0.40 & 1.30 \\
CGS KL 167 & RV & 7B & 1.64 & 1.17 & 1.40 \\
\hline
\end{tabular}

Discussion. - Leperditella? sp. A mostly resembles L. prima Sarv, 1956 from the Upper Ordovician of Estonia, but the latter species differs in having the greatest width at the midpoint of the valve and in the presence of very fine punctuation in some specimens.

Occurrence. - Interval below the Perník Bed, Dicellograptus laticeps Zone: Lejškov near Málkov, Levín - slope above the highway, Praha-Radotín - highway tunnel; interval above the Perník Bed, Metabolograptus ojsuensis Zone: one specimen probably belonging to this species was found at Zadní Třeban̆ - railway cut. 
Leperditella? sp. B

Figure 4G, H; Table 21

Material. - 10 more or less incomplete carapaces.

Description. - The valves are small to medium sized, moderately high with an oval outline. The carapace is slightly postplete. The dorsal margin is straight, cardinal angles rounded, the posterior one bigger than the anterior one. The posterior end is more broadly curved than the anterior. The greatest length is situated at or slightly above the mid-height of the valve. The convexity of the carapace is weak, with the maximum at the mid-length. The left valve overlaps the right one ventrally, whereas the right valve slightly overreaches the left valve dorsally. The hinge line is somewhat incised. The surface of the valve is smooth.

Table 21. Leperditella? sp. B, dimensions $(\mathrm{mm})$ and proportions of figured specimens.

\begin{tabular}{lccccc}
\hline Specimen & Valve & Figure & L & H & L:H \\
\hline CGS KL 45 & LV & $4 G$ & 1.03 & 0.61 & 1.69 \\
CGS KL 44 & LV & $4 \mathrm{H}$ & 0.72 & 0.44 & 1.64 \\
\hline
\end{tabular}

Discussion. - The type species Leperditella rex in its original description shares similar features with Leperditella? sp. B. such as a subovate and postplete outline, straight dorsal margin and more broadly curved posterior margin in the ventral part. Ulrich (1894) stated that the left valve is larger than the right one, whose free edges fit into a groove in Leperditella. In the genus Elliptocyprites the left valve slightly overreaches the right valve along the free margin, but the valves are strongly elongated and elliptical with a broader anterior end and of moderate to strong convexity. The decisive character to determine the orientation in our collection is the overlap. Therefore $L$. ? sp. B is oriented in the way demonstrated in the above description and illustrated figures. This material differs from other described Leperditella species, including L.? sp. A from the same formation, in having a more elongated outline, less convex carapace and distinct overlap.

Occurrence. - The Perník Bed: Zadní Třebaň - railway cut.

Family Primitiidae Ulrich \& Bassler, 1923

\section{Genus Primitiella Ulrich, 1894}

Type species. - Primitiella constricta Ulrich, 1894; Late Ordovician, Minnesota, USA.

Primitiella? sp.

Figure 4A, Table 22
Material. - 2 more or less incomplete carapaces.

Description. - The outline of the medium-sized valves is slightly postplete, rather long. The carapace is equivalved, with no distinct overlap. The dorsal margin is rather short, cardinal angles obtuse. The posterior end is more broadly rounded. The valve is angular posteriorly and slightly flattened to the anterior end from the dorsal view. The greatest width is situated in the mid-point of the valve. The lateral surface is smooth without any lobal or sulcal structures.

Table 22. Primitiella? sp., dimensions ( $\mathrm{mm}$ ) and proportions of figured specimen.

\begin{tabular}{lccccc}
\hline Specimen & Valve & Figure & L & H & L:H \\
\hline CGS KL 46 & LV & 4A & 1.09 & 0.57 & 1.91 \\
\hline
\end{tabular}

Discussion. - The type species Primitiella constricta shares an elongated outline, straight dorsal margin, narrower curved anterior margin (than the posterior one), smooth surface and distinct convexity with $P . ? \mathrm{sp}$. However, our species lacks any evidence of a sulcal depression located centrodorsally in $P$. constricta. The assignment to Primitiella is tentative.

Occurrence. - The Perník Bed: Zadní Třebaň - railway cut.

Order Podocopida Sars, 1866

Suborder Cypridocopa Jones in Chapman, 1901

Family Longisculidae Neckaja, 1966

\section{Genus Longiscula Neckaja, 1958}

Type species. - Longiscula arcuaris Neckaja, 1958; Middle Ordovician, NW Russia.

Longiscula ef. perfecta Meidla, 1993

Figures 4K, 7C; Table 23

Material. - 2 incomplete carapaces and 32 specimens on rock slabs, mostly internal moulds.

Description. - The valves are medium sized (up to $1.65 \mathrm{~mm}$ ), rather long. The outline is subtriangular. The dorsal margin is irregularly arched and broadly curved, with a longer anterior slope. No sulcal depression is developed. The ventral margin is straight to weakly concave. The posterior and anterior ends are rounded near the ventral margin, the posterior end more rounded than the anterior one. Valves are moderately convex. The greatest width is observed in the posterior part of the carapace. The left valve slightly overlaps the right valve along the ventral margin and extends shortly antero- and posterodorsally. The lateral surface of the valves is smooth. 
Table 23. Longiscula cf. perfecta Meidla, 1993, dimensions (mm) and proportions of figured specimens.

\begin{tabular}{lccccc}
\hline Specimen & Valve & Figure & L & H & L:H \\
\hline CGS KL 31 & RV & 4K & 1.13 & 0.58 & 1.95 \\
CGS KL 161b & ? LV & 7C & 0.84 & 0.43 & 1.95 \\
\hline
\end{tabular}

Discussion. - The valve morphology is very similar to that of $L$. perfecta Meidla, 1993, but the valve overlap is significantly more distinct in $L$. perfecta in comparison with our isolated carapace. The more isolated material would certainly bring a more precise determination. In the Baltic species L. tersa (Neckaja, 1966), valves share the same lateral outline but are less convex and lengthened from the dorsal view in the latter species.

Occurrence. - Interval below the Perník Bed, Dicellograptus laticeps Zone: Lejškov near Málkov, Levín - slope above the highway, Praha-Radotín - highway tunnel; the Perník Bed: Zadní Třebaň - railway cut.

\section{Longiscula sp.}

Figure 4F, Table 24

Material. - 15 more or less incomplete carapaces.

Description. - The valves are small (up to $0.7 \mathrm{~mm}$ ), the shape is moderately long to rather long. The outline is slightly subtriangular. The dorsal margin is broadly curved, the maximum height is located centrodorsally, but the anterior end is more narrowly rounded near the ventral margin. No sulcal depression is developed. The ventral margin is weakly concave. The carapace has flat to weakly concave lateral surface from the dorsal/ventral view; the posterior end is ventrally steeper than the anterior. In this case, we may observe certain variation, when some specimens have a more flattened lateral surface than others. The left valve slightly overlaps the right valve along the ventral margin; the overlap seems to be even. The lateral surface of the valves is smooth.

Table 24. Longiscula sp., dimensions ( $\mathrm{mm}$ ) and proportions of figured specimen.

\begin{tabular}{lccccc}
\hline Specimen & Valve & Figure & L & H & L:H \\
\hline CGS KL 37 & LV & 4F & 0.65 & 0.36 & 1.81 \\
\hline
\end{tabular}

Discussion. - Longiscula sp. is characteristic due to its angular outline of the lateral surface in the ventral/dorsal view that makes this species different from the other representatives of the genus including Longiscula $\mathrm{cf}$. perfecta Meidla, 1993 from the same formation. The similarity exists to the carapace of $L$. loknensis Neckaja, 1958 from the Upper Ordovician of Russia, but $L$. sp. differs in its more rounded anterior end and less sculptured surface.

Occurrence. - The Perník Bed: Zadní Třebaň - railway cut.

\section{Genus Aviacypris Schallreuter, 1977}

Type species. - Aviacypris avia Schallreuter, 1977; Late Ordovician, Germany (erratic boulder).

\section{Aviacypris? sp.}

Figures 4D, E; 8H; Table 25

Material. - More than 40 valves on rock slabs, mainly internal moulds and 3 incomplete carapaces.

Description. - Medium sized (up to $1.6 \mathrm{~mm}$ ) and very long valves with no distinct sulcus or nodes. The dorsal margin is nearly parallel to the ventral margin. The greatest length is located below the mid-height. The anterior end is arched and nearer to the ventral margin. The posterior part of the valve is slightly higher than the anterior part. An isolated internal mould shows no distinct valve overlap.

Table 25. Aviacypris? sp., dimensions ( $\mathrm{mm}$ ) and proportions of figured specimens.

\begin{tabular}{lccccc}
\hline Specimen & Valve & Figure & L & H & L:H \\
\hline CGS KL 124 & RV & $4 \mathrm{D}$ & 1.32 & 0.56 & 2.36 \\
CGS KL 163 & RV & $8 \mathrm{H}$ & 1.58 & 0.66 & 2.39 \\
CGS KL 51 & LV & 4E & 1.16 & 0.48 & 2.42 \\
\hline
\end{tabular}

Discussion. - The genus Aviacypris is characterised especially by the structure of a duplicature. This material is represented mainly by internal moulds where the interior features cannot be determined. Our material shows some external similarities such as an elongated lateral outline and lack of any distinct ridges or depressions. Aviacypris? sp. resembles A. truncata Schallreuter \& Hinz-Schallreuter, 2011 from the Upper Ordovician of Gotland, but differs in its relatively larger size, less truncate anterior and posterior ends and the lack of ventral concavity.

Occurrence. - Interval below the Perník Bed, Dicellograptus laticeps Zone: Lejškov near Málkov, Levín - slope above the highway, Praha-Radotín - highway tunnel; the Perník Bed and interval above the Perník Bed, Metabolograptus ojsuensis Zone: Zadní Třebaň - railway cut. The specimens from the interval above the Perník Bed are poorly preserved.

Suborder Metacopa Sylvester-Bradley, 1961

Superfamily Bairdiocypridacea Shaver, 1961

Family Rectellidae Neckaja, 1966 


\section{Genus Rectella Neckaja, 1958}

Type species. - Mica inaequalis Neckaja, 1952; Late Ordovician, Estonia.

\section{Rectella bublei sp. nov.}

Figure 4I, J, Table 26

Holotype. - Isolated carapace, CGS KL 12 (Fig. 4I).

Paratype. - Isolated carapace, CGS KL 15 (Fig. 4J).

Type horizon and locality. - Králův Dvůr Formation, the Perník Bed interval; uppermost Králodvorian, topmost Katian. Zadní Třebaň - railway cut, Czech Republic; Prague Basin.

Material. - 6 incomplete isolated carapaces.

Etymology. - After Jan Buble, Czech graphic designer and typographer.

Diagnosis. - Subquadrate valves of small size and rather long shape. Dorsal and ventral margins parallel. Distinct straight dorsal margin. Left-over-right overlap, clearly pronounced. Carapace moderately convex. Lateral surface smooth.

Description. - The carapace is small (up to $0.8 \mathrm{~mm}$ ), elongate, inequivalved and subquadrate in the lateral view. Dorsal and ventral margins are parallel to each other; the dorsal margin is straight, the ventral weakly convex. Cardinal angles are obtuse. Anterior and posterior ends are rounded near the ventral margin, the posterior end is more pointed than the anterior one. The greatest length is below the mid-height. The left valve overlaps the right one along the ventral margin and extending antero- and posterodorsally. The ventral overlap is slightly deeper midventrally. The hinge line is weakly depressed. The lateral surface is smooth.

Table 26. Rectella bublei sp. nov., dimensions ( $\mathrm{mm}$ ) and proportions of figured specimens.

\begin{tabular}{lccccc}
\hline Specimen & Valve & Figure & L & H & L:H \\
\hline CGS KL 12 holotype & RV & 4I & 0.80 & 0.41 & 1.95 \\
CGS KL 15 paratype & RV & 4J & 0.82 & 0.42 & 1.95 \\
\hline
\end{tabular}

Discussion. - Rectella bublei sp. nov. resembles R. nais Neckaja, 1958 from which it can be distinguished by its more elongated and quadrated outline and by the lack of an angular protrusion in the posteroventral part of the right valve that overreaches the posteroventral margin of the left one. In comparison with $R$. explanata Meidla, 1996, $R$. bublei has a more elongated outline and dorsal margin nearly parallel to the ventral one, which is more concave in $R$. explanata.
R. romboformis Neckaja, 1966 differs from the new species in its more pronounced overlap in the ventral part of the valve and more rounded cardinal angles.

Occurrence. - The Perník Bed: Zadní Třebaň - railway cut.

Superfamily Healdiacea Harlton, 1933

Family Healdiidae Harlton, 1933

\section{Genus Cytherellina Jones \& Holl, 1869}

Type species. - Beyrichia siliqua Jones, 1855; Silurian, Ludlow, England.

Cytherellina? fugax (Barrande, 1872)

Figure 7J, K; Table 27

1872 Primit. fugax. Barr.; Barrande, p. 548, pl. 26, fig. 7a-d. 1934 Primitia (? Bythocypris) fugax Barrande. - Bassler \& Kellett, p. 444.

1954 Primitia fugax Barr. - Hughes, p. 43.

1966 Parapyxion (?) fugax (Barr.). - Havlíček \& Vaněk, p. 60 .

1979 Cytherellina (?) fugax (Barrande, 1872). - Přribyl, p. 101, text-figs 7.5, 14.5-6.

Lectotype. - Internal mould of the right valve, NM L 8854, figured by Barrande (1872, pl. 26, fig. 7a, b), refigured by Přibyl $(1979$, text-figs $7.5,14.6)$ and herein in Fig. 7J; designated by Přibyl (1979).

Paralectotype. - Internal mould of the right valve, NM L 8855 , figured by Barrande (1872, pl. 26, fig. 7 c, d), refigured by Přibyl (1979, text-fig. 14.5) and herein in Fig. 7K; designated by Přibyl (1979).

Type horizon and locality. - Králův Dvůr Formation, below the Perník Bed interval; Králodvorian, upper Katian. Králův Dvůr, Czech Republic; Prague Basin.

Material. -4 internal moulds on rock slabs.

Diagnosis. - Valves of medium size, elongated. Dorsal margin arched, ventral margin straight to weakly convex. Circular inflation-muscle spot with a shallow depression present on the internal mould.

Description. - The carapace is medium sized and very long. The dorsal margin is gently arched, posterior and the anterior ends near the ventral margin. Moulds are moderately inflated posteriorly. The lateral surface of internal moulds is smooth, with a vague circular inflation in the anterocentral area bordered by weakly developed depressions as a reflection of the internal surface structures of the valve. 
Discussion. - Cytherellina? fugax (Barrande, 1872) resembles Longisyltherella erratica Schallreuter \& Hinz-Schallreuter, 2011 from the Upper Ordovician of Gotland in its outline and presence of the muscle spot. The distinguishing features in Cytherellina are situated primarily on the interior surface of the valves, such as an adductorial recess which is reflected as a node-like inflation surrounded by two distinct depressions, as it is described in the type species C. siliqua from the Ludlow Series of England. However, since we are not able to study external morphological characters (e.g. typical left valve overlap), we decided to keep the previous tentative genus assignment.

Table 27. Cytherellina? fugax (Barrande, 1872), dimensions ( $\mathrm{mm})$ and proportions of figured specimens.

\begin{tabular}{lccccr}
\hline Specimen & Valve & Figure & L & H & L:H \\
\hline $\begin{array}{l}\text { NM L 8854 lectotype } \\
\text { NM L 8855 }\end{array}$ & RV & $>1.46$ & 0.66 & $>2.21$ \\
paralectotype & RV & $7 \mathrm{~K}$ & 1.20 & 0.58 & 2.07 \\
\hline
\end{tabular}

Occurrence. - Interval below the Perník Bed: Králův Dvůr, slope above the hippodrome in Praha-Velká Chuchle.

Ostracoda incertae sedis

The following taxa were described as belonging to ostracods by Barrande (1872) from the Králův Dvưr Formation. They are represented by poorly preserved moulds on rock slabs and we consider these taxa to be nomina dubia.

\section{"Entomozoe" rara (Barrande, 1872)}

Figure 7L

1872 Entom. rara. Barr.; Barrande, p. 516, pl. 25, figs 23, 24.

1873 Entomis rara Barr. - Jones, p. 416.

1934 Entomis rara Barrande. - Bassler \& Kellett, p. 305.

1950 "Entomis" rara Barr. - Přibyl, p. 2.

1954 Entomis rara Barr. - Hughes, p. 42.

1966 “Entomozoe” rara (Barr.). - Havlíček \& Vaněk, p. 60.

1979 Entomozoe rara (Barrande, 1872). - Přibyl, p. 106, text-fig. 6.10.

Holotype. - Left internal mould on a rock slab, NM L 8843 , originally figured by Barrande (1872, pl. 25, figs 23, 24), refigured by Přibyl (1979, text-fig. 6.10) and herein in Fig. 7L; designated by Přibyl (1979) by monotypy.

Type horizon and locality. - Králův Dvůr Formation, below the Perník Bed interval; interval with Anticostia teres and Styracograptus lobatus; lower Králodvorian, middle Katian. Lejškov near Málkov, Czech Republic; Prague Basin.

Material. - Only the holotype specimen.
Description. - The valve is very large ( $13.55 \mathrm{~mm}$ long) and rather long. The weakly convex internal mould has an elongated outline in the lateral view and reveals the presence of a structure similar to adductorial sulcus $\mathrm{S}_{2}$ extending ventrally up to the mid-height of the valve. Other diagnostic features cannot be recognised.

Discussion. - Our specimen shows some of the typical features of the predominantly Silurian genus Entomozoe Prribyl, 1950, the assignment of which to ostracods is doubtful (for different opinions on the systematic position of the genus see Siveter \& Vannier 1990 and Vannier \& Abe 1992).

Occurrence. - Interval below the Perník Bed, interval with Anticostia teres and Styracograptus lobatus: Lejškov near Málkov.

\section{"Beyrichia" barbara Barrande, 1872 \\ Figure 7I}

1872 Beyrich? barbara. Barr.; Barrande, p. 500, pl. 27, fig. $9 \mathrm{a}, \mathrm{b}$.

1979 “Beyrichia” barbara Barrande. - Přibyl, p. 107.

Holotype. - Poorly preserved internal mould on a rock slab, NM L 8853, figured by Barrande (1872, pl. 27, fig. 9a, b) and refigured herein in Fig. 7I; designated by Přibyl (1979) by monotypy.

Type horizon and locality. - Králův Dvůr Formation, below the Perník Bed interval; Králodvorian, upper Katian. Králův Dvůr, Czech Republic; Prague Basin.

Material. - Only the holotype specimen.

Description. - The poorly preserved internal mould attains a relatively large size $(3.86 \mathrm{~mm}$ long). The ventral margin has a pointed edge near the mid-length of the valve. Just above, there is a depression leading toward the dorsal margin. The lateral surface suggests evidence of granulose structures.

Discussion. - Already Přibyl (1979) expressed doubts about Barrande's assignment of this specimen to Ostracoda. As no other diagnostic characters can be recognised, we share Přibyl's opinion.

Occurrence. - Interval below the Perník Bed: Králův Dvưr.

\section{Stratigraphic distribution}

The stratigraphic information about the studied specimens is of various precision and relevance ( $c f$. Shaw 2000). Those recently collected from the Perník Bed and Metabolograptus 
ojsuensis Zone are related to the thin units of the exact stratigraphic position. On the other hand, the material from historical collections is usually poorly dated. In addition, the levels of origin of some recent collections from grey and greyish-green shale representing most of the formation cannot be identified with sufficient accuracy. Some species are confined to or appear in the Dicellograptus laticeps Zone [Euprimites (E.) kralodvorensis, Ningulella? sp., Aechmina sp., Crescentilla laciniata and Leperditella? sp. A], one taxon (the dubious "Entomozoe" rara) was found only in the "Lejškov facies" belonging to the interval with Anticostia teres and Styracograptus lobatus in the lower part of the formation but relations of others to graptolite zones, trilobite or brachiopod associations are plausible. Therefore three stratigraphic intervals were distinguished as justified also above: below, inside and above the Perník Bed (Fig. 2, Tab. 28).

The maximum ostracod diversity falls into the interval below the Perník Bed as a whole. It comprises twenty species, ten of which are limited to this part of the formation. The diversity decreases to fifteen species (including two questionable occurrences) in the overlying Perník Bed. Seven of them (two questionable) continue from the underlying shales, eight occur only in this particular layer. Higher in the section, the diversity is reduced to six species (including two questionable occurrences) in shale overlying the Perník Bed (Tab. 28).

Overall trends in the pattern of the stratigraphic ranges are clearly visible. The half of twenty species occurring below the Perník Bed continues upward. Eight additional species appear in the Perník Bed but none of them ranges above this layer. Only opportunists, which are represented by more than a half of species, range from the interval below the Perník Bed higher.

The species with identical or similar stratigraphic ranges form four distinct groups (Tab. 28).

We are inclined to interpret the succession of distinct ostracod associations in terms of climatic changes. Vandenbroucke et al. (2010) considered a relatively gradual global cooling from Sandbian to reaching its maximum during the Hirnantian glaciation. Elrick et al. (2013) analyzed a course of the cooling through climatic fluctuations. In accordance with both mentioned models, the ostracod association overturns in the Králův Dvůr Formation probably indicate climatic changes influenced by variations of hydrosphere temperatures (e.g. Elrick et al. 2013) related to the ocean current tracks and their intensities (e.g. Hermann et al. 2004) accompanied by facies shifts (e.g. Cherns \& Wheeley 2007) caused at least partly by sea level fluctuations (e.g. Hermann et al. 2004, Elrick et al. 2013) during the prolonged global cooling. On the other hand, it is difficult to identify any prominent warming period such as the Boda event (Fortey \& Cocks 2005, discussed by Melchin et al. 2013) based on the ostracod associations. However, if we allow its existence ( $c f$. Cherns \& Wheeley 2007) and it was influencing the Prague Basin, then it was below the Perník Bed. Such an assumption would be in accordance with the opinion of Kraft et al. (2015) and fits the interpretation by Havlíček (1989).

A prominent ostracod association with new taxa appeared when the Perník Bed deposited. Such an influx of new faunal elements is a general feature of this stratigraphic unit (Havlíček \& Mergl 1982, Štorch \& Mergl 1989); an overall result as a mixture of new and earlier taxa dwelling the Prague Basin is similar to other groups, e.g. trilobites (Shaw 2000). A significant number of newly appeared species is probably related not only to the climatic change but also to a carbonate shift in sedimentation. A conspicuous reduction of the ostracods occurring below the Perník Bed and their substitution for the new taxa, which raised the diversity up, better corresponds to interpretations of the Perník Bed as a response of the sea level drop reflecting the global cooling (e.g. Budil et al. 2011b, Mergl 2011b, Mitchell et al. 2011) rather than warming (e.g. Štorch \& Mergl 1989, Shaw 2000, Fatka \& Mergl 2009). A recurrence of the greyish-green shale sedimentation above the Perník Bed was accompanied by disappearance of all those taxa and surviving of a small fraction derived from the original pre-Perník Bed association together with the cold water Mucronaspis Trilobite Association (e.g. Štorch \& Mergl 1989). It supports the model emphasizing sea level changes accompanied with substrate replacement in course of climatic oscillations during the general cooling period.

\section{Palaeobiogeography and biodiversity}

The comparison analysis between the coeval ostracod assemblages of three major Ordovician palaeogeographical domains: Laurentia, Avalonia and Baltica, and that of the Králův Dvůr Formation ostracod assemblages were made (Tab. 29) to provide a palaeobiogeographic correlation of these palaeoareas. The Late Ordovician (mid Katian-early Hirnantian) ostracods from the other palaeogeographical regions such as Ibero-Armorica, Siberia and Precordillera share fewer taxa in common with the Bohemian material; therefore, we consider their comparison with other regions as being irrelevant for the time being.

The Králův Dvůr Formation corresponds to the Králodvorian Stage in the regional stratigraphic scale (for details about the chronostratigraphic unit see Havlíček \& Marek 1973, Kraft et al. 2015 and Gutierréz-Marco et al. 2017). It is correlated with Vormsi to the base of the Porkuni Stage in Baltica. This palaeocontinent is represented by data from Estonia, Latvia and Lithuania (Sidaravičiene 1992, Meidla 1996), Sweden (Henningsmoen 1948, Meidla 2007, Truuver et al. 2012), glacial erratic boulders of northern Germany and adjacent areas (Schallreuter 1977, 1981, 
Table 28. Stratigraphic ranges of the ostracod species in the Králův Dvưr Formation related to three reasonably distinguished intervals. The species form clusters (differently shaded) typical by their stratigraphic range patterns. The species confined to narrow intervals are darkly shaded, those ones of a wider stratigraphic range are marked by a lighter grey. The interpretations of the species clusters are in the right column.

\begin{tabular}{|c|c|c|c|c|}
\hline Species & below Perník Bed & Perník Bed & above Perník Bed & \\
\hline Platybolbina runica & - & & & \\
\hline Ningulella? sp. & - & & & \\
\hline Aechmina sp. & $\bullet$ & & & $\stackrel{\overrightarrow{0}}{=}$ \\
\hline Crescentilla laciniata & - & & & $\frac{3}{3}$ \\
\hline Pseudulrichia risumata & $\bullet$ & & &. \\
\hline Warthinia trinoda & • & & & :E \\
\hline Parenthatia hanamiloslavensis & $\bullet$ & & & 足 \\
\hline Orechina punctata & • & & & $\bar{E}$ \\
\hline Easchmidtella nuda & $\bullet$ & & & \\
\hline Cytherellina? fugax & - & & & \\
\hline Uhakiella barrandensis & • & $?$ & & \\
\hline Pseudulrichia lucberkensis & - & $?$ & & $\stackrel{\infty}{\Xi} \stackrel{0}{=}$ \\
\hline Euprimites (Euprimites) kralodvorensis & $\bullet$ & - & & $8 \frac{0}{0}$ \\
\hline Longiscula cf. perfecta & • & - & & \\
\hline Spinigerites ostrovites & - & • & - & \\
\hline Parapyxionella prunella & • & • & • & $\frac{\infty}{\infty}$ \\
\hline Aviacypris? sp. & - & • & • & $\Xi$ \\
\hline Sigmobolbina? sp. & $\bullet$ & & $\bullet$ & 官 \\
\hline Leperditella? sp. A & - & & $?$ & $0^{2}$ \\
\hline Scanipisthia rectangularis & - & & $?$ & \\
\hline Aechmina? meidlai & & $\bullet$ & & \\
\hline Spinigerites sp. & & $\bullet$ & & \\
\hline Baltonotella? admirabilis & & • & & 苟 \\
\hline Cryptophyllus sp. & & • & & $\cdot \stackrel{.00}{\Xi}$ \\
\hline Leperditella? sp. B & & • & & .0 \\
\hline Primitiella? sp. & & • & & 8 \\
\hline Longiscula sp. & & $\bullet$ & & \\
\hline Rectella bublei & & - & & \\
\hline
\end{tabular}

1984, 1986, 1987, 1990b; Schallreuter \& Hinz-Schallreuter 2011 ) and from Pskov region of eastern Russia (Nõlvak et al. 1989, Meidla 1996).

Ostracod distribution from Laurentia (Maysvillian-base of Gamachian Stage) is documented from Iowa (Spivey 1939, Levinson 1951), Missouri (Keenan 1951), Minnesota (Burr \& Swain 1965, Swain 1987), Kentucky (Warshauer \& Berdan 1982), from the Canadian Whittaker Formation (Copeland 1977, Copeland 1989) and Vauréal and Ellis Bay formations of Anticosti Island, Quebec (Bolton 1970; Copeland 1970, 1973; Barnes \& McCracken 1981), which are recently considered as probably pre-Hirnantian (more in Meidla et al. 2013 and references therein).

Williams et al. (2001) documented ostracod assemblages of Avalonia (Pusgillian-Rawtheyan Stage) from the
Cautley Mudstone Formation of northern England. The comprehensive study on Late Ordovician ostracod faunas of England was also provided by Siveter (2009).

The dataset of genera (Tab. 29) clearly illustrates that there are three main groups. The first is composed of the cosmopolitan taxa occurring in three or all four studied palaeoareas. It is represented by thirteen genera, i.e. more than half the number of all observed taxa. Eight of them are fully proven because of reliable determinations and obvious occurrences in all areas, five include an uncertain presence in one or two palaeoareas. Most of them reached Laurentia in the palaeotropics. Only a minority were limited to the palaeoareas in higher latitudes. The next eight genera constitute a group of those recorded in two palaeoareas. Except for one considered to belong to this group 
Table 29. Distribution of the coeval ostracod genera occurring in the Králův Dvůr Formation and three selected palaeocontinents. Note that these palaeoareas cover different palaeoclimatic zones. Problematic taxa are omitted.

\begin{tabular}{|c|c|c|c|c|}
\hline Genus & $\begin{array}{c}\text { Prague } \\
\text { Basin }\end{array}$ & Baltica & Avalonia & Laurentia \\
\hline Platybolbina & • & • & • & • \\
\hline Aechmina & - & - & - & - \\
\hline Pseudulrichia & - & - & - & - \\
\hline Spinigerites & • & & - & - \\
\hline Warthinia & - & & - & - \\
\hline Cryptophyllus & • & • & & • \\
\hline Leperditella & $?$ & • & & - \\
\hline Ningulella & $?$ & - & & $?$ \\
\hline Cytherellina & $?$ & & & $?$ \\
\hline Euprimites & - & - & - & \\
\hline Longiscula & • & • & • & \\
\hline Uhakiella & - & - & $?$ & \\
\hline Baltonotella & $?$ & - & - & \\
\hline Primitiella & $?$ & • & $?$ & \\
\hline Sigmobolbina & $?$ & - & & \\
\hline Crescentilla & - & - & & \\
\hline Orechina & - & - & & \\
\hline Easchmidtella & • & • & & \\
\hline Rectella & • & • & & \\
\hline Scanipisthia & • & • & & \\
\hline Aviacypris & $?$ & - & & \\
\hline Parenthatia & - & & & \\
\hline Parapyxionella & • & & & \\
\hline
\end{tabular}

with reserve, the seven taxa (six with assurance) occur in the Prague Basin and Baltica. Exclusive pair-occurrences in the Prague Basin and Avalonia or Laurentia have not been proved. The last group is composed of two periGondwanan endemic taxa. It is typical not only by their presence but also by the high abundance mainly of two of them (Parapyxionella, Parenthatia).

The similarities between palaeoareas related to the genera occurring in the mid-Katian to earliest Hirnantian of the Prague Basin were quantified through the Jaccard index and expressed in percents, i.e. the index multiplied by a hundred. Two cases were taken into account to solve uncertain occurrences because of doubtful determinations. The similarity indexes were calculated with all questionable occurrences first as present (coded as 1) and second as absent (coded as 0 ). The overall results were similar in general and are to be interpreted in the same way. Thus, the former case was primarily used to illustrate relationships between palaeoareas because the differences are more clearly pronounced (Fig. 9). The close relationships to Baltica, weaker connections to comparably close but more westward Avalonia and the relatively strong influence of far located Laurentia are characteristic for ostracod faunas of the Králův Dvưr Formation. It is in a good agreement with the conclusions of Schallreuter \& Krüta (1988) and also Havlíček et al. (1994) who based their study mainly on trilobites and brachiopods. On the contrary, palaeocurrent reconstructions such as by Pereira et al. (2015) seem to be improbable because it can be expected that such a current pattern would cause a different relation of similarities. Other current models, e.g. Webby (2002), fit and justify the observed similarities of palaeoareas much better. It is worth noting that migration pathways between the Prague Basin, situated in the outer shelf of Gondwana (i.e. northern periGondwana), and Baltica were accomplished over the Rheic Ocean in its maximum extent. On the other hand, ostracods could migrate effectively from or to Laurentia through the bridges of gradually approaching Avalonia and Baltica, i.e. narrowing Iapetus Ocean (documented by Schallreuter \& Siveter 1985 in detail). Relatively intensive migration between Baltica and Avalonia is also obvious.

As stated above, the Bohemian ostracods show strongest biogeographical links at the generic level with late Katian to earliest Hirnantian faunas of Baltoscandia. These regions have eighteen genera in common. Binodicopes with six genera and palaeocopes with five genera in common are the dominant components of these regions. Generic affinities between ostracods of the Králův Dvůr Formation and equivalent strata in Avalonia are less numerous, with ten genera in common. The binodicope taxa are prevalent among nine genera in common between the Prague Basin and Laurentia and show the weakest regional connection. There are three ostracod genera common for all studied regions, two of them are geographically widespread binodicopes, namely Aechmina and Pseudulrichia, and one is the palaeocope genus Platybolbina. Another conspecific binodicope ostracod recorded from both Avalonia (Williams et al. 2001) and Laurentia (Copeland 1973) is the species Spinigerites unicornis (Ulrich, 1879) sensu Copeland (1973). Williams et al. (2001) also consider British species Warthinia cf. nodosa (Ulrich, 1890) to be probably conspecific with Warthinia nodosa established from North America (e.g. Keenan 1951, Copeland 1970) extending its stratigraphical range to the late Richmondian Stage. The one and only representative of its genus, Scanipisthia rectangularis (Troedsson, 1918), is a well-known, typical Hirnantian species mostly bounded to Baltica (e.g. Meidla 1996, Meidla et al. 2011) with a record also from the peri-Gondwanan Cellon Section of the Carnic Alps (Schallreuter 1990a). Its occurrence in the pre-Hirnantian strata in the Prague Basin represents the earliest occurrence of the species and may be supposed as a record of a climate-caused migration of the species to warmer latitudes in the course of cooling. 

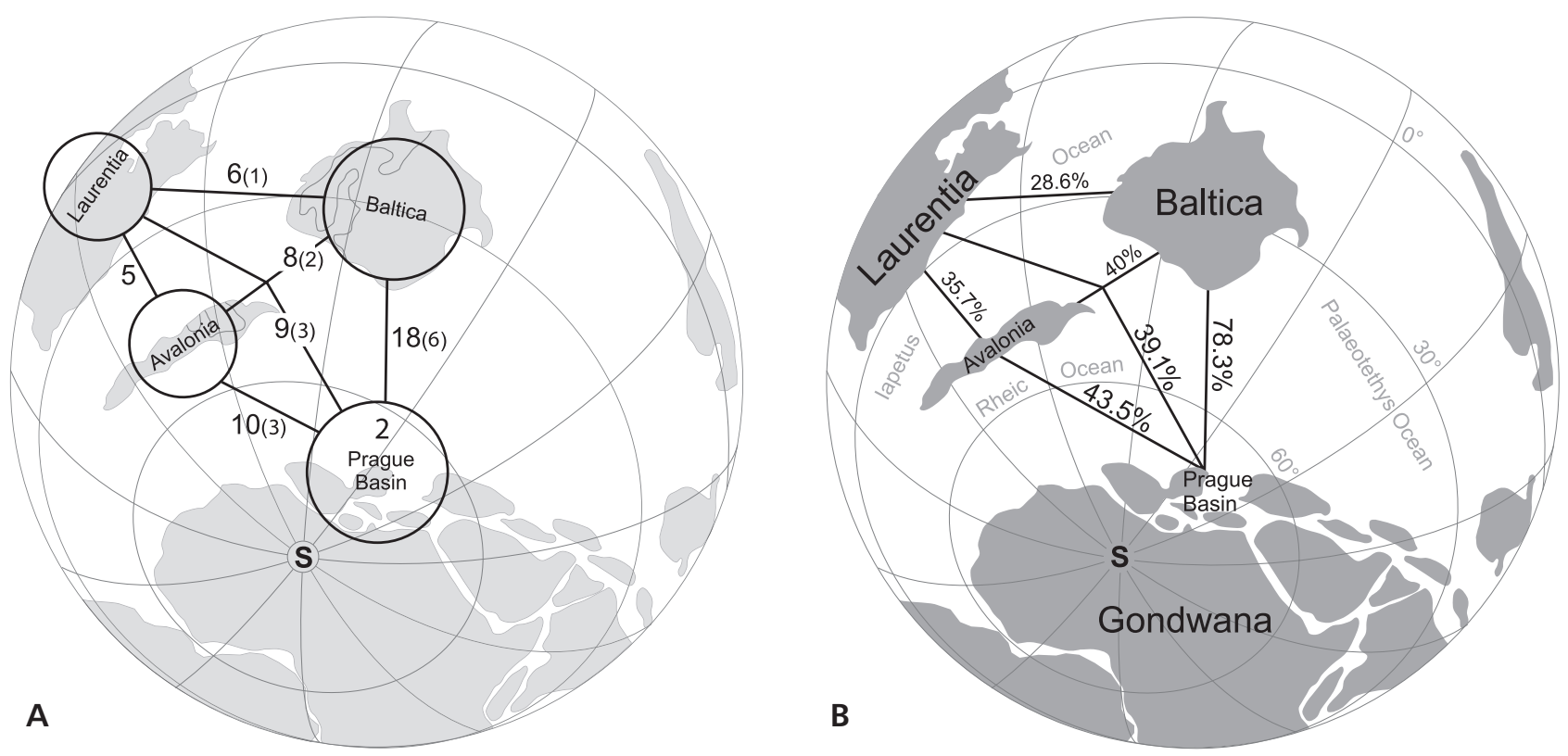

Figure 9. Palaeobiogeographic relationships of ostracod assemblages based on genera occurring in the Králův Dvưr Formation of the Prague Basin. The diagram is placed to the palaeogegraphic map to illustrate the positions of the studied palaeoareas. $\bullet$ A - simple illustration of relations through number of joint genera on lines for each pair of palaeoareas. Big numbers are totals including those uncertainly occurred which are indicated by small numbers in brackets. Number in the circle of the Prague Basin represents endemic taxa. $\bullet$ - the relationships expressed by Jaccard indexes converted to percentage. All occurrences including uncertain coded as present. (The modified background map in a suitable projection after Vecoli \& Le Hérissé 2004.)

According to the published data of compared regions, some of the genera seem to be restricted only to the late Katian of Bohemia. The species of the genus Parenthatia Kay, 1940 of the North America region are typical of the early Katian (e.g. P. camerata Kay, 1940; P. sadievillensis Warshauer \& Berdan, 1982) and the genus Parapyxionella described by Prribyl (1979) seems to be endemic in the Prague Basin.

Palaeocopes are considered as a dominant ostracod group in the earliest Late Ordovician with an apparent decrease terminating in the latest Ordovician with a little increase of binodicopes and podocopes (Meidla et al. 2013). The ostracod record from the Králův Dvůr Formation quite follows this diversity pattern, with binodicopes being the most important ostracod group, comprising nearly half of all described genera, whereas the suborder Palaeocopa and the order Podocopa are less significant groups in this interval. Vannier et al. (1989) postulated an ecological model for the relationships between assemblage composition, diversity and related environmental conditions in Ordovician ostracods inhabiting marine shelf environments. Low-diversity binodicope faunas occur in clastic sediments deposited under unstable conditions, while high-diversity palaeocope faunas occur in carbonates deposited in stable environments. The Bohemian ostracod fauna reflects the diversity of binodicopes and palaeocopes in shaly layers below the Perník Bed as being higher than in the carbonate-rich Perník Bed, with the prevalence of binodicopes. The widespread binodicope genera such as Pseudulrichia, Warthinia, Spinigerites and Aechmina are considered to be typical of deep shelf settings and cooler-water benthic palaeoenvironments (Meidla 1996; Copeland 1977; Williams et al. 2001, 2003). The occurrence of the eridostracan genus Cryptophyllus is often associated with shallow-marine marginal environments (Olempska 2012 and references therein) which is supported by Bohemian material recorded from the carbonaceous Perník Bed.

The data on the stratigraphic distribution of the species (Tab. 28) and palaeogeographic distribution of studied genera (Tab. 29) were combined to test if there are any changes in palaeogeographic affinities related to stratigraphic intervals throughout the Králův Dvůr Formation. As a result, no preference between any of four ostracod associations and studied palaeoareas was observed.

\section{Conclusions}

Ostracod associations of the Králův Dvưr Formation are among the richest and most diversified in the Ordovician of the Prague Basin. They comprise twenty-three genera with twenty-eight species. This is equal to the Bohdalec Formation, the unit formerly considered to yield the richest ostracod fauna in the Ordovician of the Prague Basin (Schallreuter \& Krůta 1988). Although the grey to greyish-green shale forms the principal thickness of the formation and has been studied for decades, it provided 
a limited number of ostracod taxa for previous studies. This number was significantly extended herein. Moreover, there has been an omitted succession with the diversified ostracod associations in the upper part of the Králův Dvưr Formation. In these strata, however, Štorch \& Mergl (1989) suggested more than twenty species and Mergl (2011b) some fifteen species merely in the Perník Bed (level B1a of Štorch \& Mergl 1989). These associations are composed of new or first identified taxa described herein. The pattern of their stratigraphic ranges is suggested to reflect strongly the Late Ordovician climatic changes.

Ostracod association in the Perník Bed substituted the long-ranging and probably stable association of the grey to greyish green shale (coeval with the Amphitryon-Kloucekia Trilobite Association sensu Budil et al. 2011b) and was replaced by the next association in the layer just above the Perník Bed. The gradual decrease of species typical for the association below the Perník Bed, surviving solely of opportunists from the early association and indication of Scanipisthia rectangularis migration to the lower latitude of Baltica, altogether show gradual cooling oscillations rather than any interposed warming period. It illustrates the Perník Bed interpretation as a cooling indication (Cherns \& Wheeley 2007, Budil et al. 2011b, Mergl 2011b, Mitchell et al. 2011). In summary, we consider the succession of the ostracod associations of the Králův Dvůr Formation as reflecting general cooling with climatic oscillations accompanied by facies changes which caused migrations and prominent taxonomic turnovers, but did not affect a few conspicuously stable eurythermal species.

The most abundant endemic peri-Gondwanan genera Parapyxionella and Parenthatia, and the most common opportunistic species Parapyxionella prunella, are typical for the ostracod fauna of the Králův Dvůr Formation. However, its overall dominance of binodicopes and palaeocopes is considered to be strongly influenced by the significant relationship of the peri-Gondwanan Prague Basin to Baltica and the much weaker affinity to Avalonia and Laurentia during the mid Katian to earliest Hirnantian.

\section{Acknowledgements}

We are deeply indebted to Tõnu Meidla (University of Tartu) for his kind help with processing the key material from the Perník Bed, for his valuable advice during preparation of the manuscript and very detailed and helpful review. For his very useful review, we would also like to thank Michal Mergl (West Bohemian University in Pilsen). We are grateful to Ondřej Zicha for access to the specimens from his private collection and donating the holotype of Crescentilla laciniata to the Czech Geological Survey. We wish to thank Petr Budil (Czech Geological Survey) and Martin Valent (National Museum in Prague) for providing access to the specimens held in the collections of their institutes. Anna Tószögyová (Center for Theoretical Study, Charles University) consulted statistical analyses and Jan Buble supported with the graphic form of the figures. This paper was supported by the project Progress Q45 of Charles University, Prague (to P.K.).

\section{References}

AdAMCZAK, F. 1961. Eridostraca - a new suborder of ostracodes and its phylogenetic significance. Acta Palaeontologica Polonica 6(1), 29-102.

Barnes, C.R. \& McCraken, A.D. 1981. Early Silurian chronostratigraphy and a proposed Ordovician-Silurian stratotype, Anticosti Island, Québec. 71-79. In LESPÉRANCE, P.J. (ed.) International Union of Geological Sciences, Subcommission on Silurian Stratigraphy, Ordovician-Silurian Boundary Working Group, Field Meeting, Anticosti-Gaspé, Québec. Volume 2, Stratigraphy and Paleontology.

Barrande, J. 1872. Systême silurien du centre de la Bohême. 1ère Partie: Recherches Paléontologiques. Supplement au Vol. 1. Trilobites, Crustacés divers et Poissons. 647 pp., 35 pls. Privately published, Prague \& Paris.

Bassler, R.S. \& Kellett, B. 1934. Bibliographic index of Paleozoic Ostracoda. Geological Society of America Special Papers 1, 1-500. DOI 10.1130/SPE1-p1

Becker, G. \& Bless, M.J.M. 1974. Ostracode stratigraphy of the Ardenno-Rhenish Devonian and Dinantian. International Symposium on Belgian Micropaleontological Limits Publication 1, 1-52.

Bigsby, J.J. 1868. The Flora and Fauna of the Silurian Period. With Addenda (from Recent Acquisitions). Thesaurus Siluricus. 214 pp. John van Voorst, Paternoster Row., London.

Blumenstengel, H. 1965. Zur Ostrakodenfauna eines Kalkgerölls aus dem Thüringer Lederschiefer (Ordovizium). Freiberger Forschungshefte C 182, 63-78.

Bolton, T.E. 1970. Subsurface Ordovician fauna, Anticosti Island, Quebec. Geological Survey of Canada, Bulletin 187,1-145. DOI 10.4095/102330

Bonnema, J.H. 1909. Beitrag zur Kenntnis der Ostrakoden der Kuckersschen Schicht (C2). Mitteilungen aus dem Mineralogischen-Geologischen Institut der Reichs-Universitat zu Groningen 2(1), 1-84.

BOUČEK, B. 1928. O vrstvách zahořanských $-\mathrm{d}_{\varepsilon}$ českého ordoviku. Rozpravy České akademie věd a umění, Třida II (matematickoprírodovédecká) 37, 33, 1-59.

BoučEK, B. 1936. Die Ostracoden des böhmischen Ludlows (Stufe e $\beta$ ). Neues Jahrbuch für Mineralogie, Geologie und Paläontologie 76, 31-98.

Brenchley, P.J. \& ŠTorch, P. 1989. Environmental changes in the Hirnantian (upper Ordovician) of the Prague Basin, Czechoslovakia. Geological Journal 24(3), 165-181. DOI 10.1002/gj.3350240302

Budil, P., FatKa, O., KoláR̆, P. \& David, M. 2011a. Arthrorhachis Hawle \& Corda, 1847 (Agnostida) in the Prague Basin 
(Barrandian area, Czech Republic) revisited. Bulletin of Geosciences 86(4), 707-724.

DOI 10.3140/bull.geosci.1262

Budil, P., Fatka, O., Mergl, M. \& David, M. 2011b. Trilobite biostratigraphy of the Králův Dvurr Formation (upper Katian, Prague Basin, Czech Republic): global faunal changes or facies-related distribution? Geologické výzkumy na Moravě a ve Slezsku 18(1), 4-10.

Burr, J.H. JR. \& SwaIn, F.M. 1965. Ostracoda of the Dubuque and Maquoketa Formations of Minnesota and northern Iowa. Minnesota Geological Survey Special Publication 3, 1-40.

Cherns, L. \& Wheeley, J.R. 2007. A pre-Hirnantian (Late Ordovician) interval of global cooling - The Boda event reassessed. Palaeogeography, Palaeoclimatology, Palaeoecology, 251(3), 449-460. DOI 10.1016/j.palaeo.2007.04.010

CHLupÁČ, I. 1951a. Stratigrafické poměry králodvorských břidlic u Karlíka a Zadní Třebáně. Věstník Ústředního ústavu geologického 26, 194-212.

CHLupÁč, I. 1951b. Profil králodvorskými břidlicemi (Ashgillian) u Velké Chuchle. Věstnik Královské české společnosti nauk, třida matematicko-prírodovédecká 1950(1), 1-10.

CHLupéč, I. 1953. Poznámky ke stratigrafii králodvorských břidlic v okolí Litně. Časopis Národního musea, oddil př́rodovědný $122,28-33$.

ChlupÁČ, I. 1999. Barrande's stratigraphic concepts, palaeontological localities and tradition - comparison with the present state. Journal of the Czech Geological Society 44(1-2), 3-30.

Copeland, M.J. 1970. Ostracoda from the Vauréal Formation (Upper Ordovician) of Anticosti Island, Quebec. Bulletin of the Geological Survey of Canada 187, 15-29.

DOI 10.4095/102327

Copeland, M.J. 1973. Ostracoda from the Ellis Bay Formation (Ordovician), Anticosti Island, Quebec. Geological Survey of Canada Paper 72(43), 1-49.

CoPeland, M.J. 1977. Early Palaeozoic Ostracoda from southwestern district of Mackenzie, and Yukon Territory. Geological Survey of Canada, Bulletin 275, 1-88. DOI 10.4095/103068

Copeland, M.J. 1989. Silicified upper Ordovician-lower Silurian ostracodes from the Avalanche Lake area, southwestern District of Mackenzie. Geological Survey of Canada, Bulletin 341, 1-100. DOI 10.4095/127317

Coryell, H.N. \& SchencK, H.G. 1941. Type of the Ordovician ostracode genus Leperditella. Journal of Paleontology 15(2), 176-177.

Elrick, M., Reardon, D., Labor, W., Martin, J., Desrochers, A. \& Pope, M. 2013. Orbital-scale climate change and glacioeustasy during the early Late Ordovician (pre-Hirnantian) determined from $\delta^{18} \mathrm{O}$ values in marine apatite. Geology 41(7), 775-778. DOI $10.1130 / \mathrm{G} 34363.1$

FatKa, O. \& Mergl, M. 2009. The "microcontinent" Perunica: status and story 15 years after conception, 65-102. In BASSETT, M.G. (ed.) Early Palaeozoic peri-Gondwanan terranes: New insights from tectonics and biogeography. Geological Society London, Special Publications 325.

Fortey, R.A. \& Cocks, L.R.M. 2005. Late Ordovician global warming - The Boda event. Geology, 33(5), 405-408. DOI $10.1130 / \mathrm{G} 21180.1$

Gailĩte, L. 1968. Paleontological characteristic of adjacent Ordovician and Silurian deposits in Latvia, 130-138. In Grigelis, A.A. (ed.) Stratigraphy of the Baltic Lower Paleozoic and its Correlation with Other Areas. Mintis, Vilnius. [in Russian with English summary]

Gailīte, L. 1970. Ostracodes from the Kuldiga Member of the Upper Ordovician of Latvia, 19-32. In Grigelis, A.A. (ed.) Palaeontology and Stratigraphy of the Baltic and the Byelorussia. Mintis, Vilnius. [in Russian with English summary]

GAILīte, L. 1975. Ostracoda from the Middle and Upper Ordovician boundary in West Latvia, 59-67. In Grigelis, A.A. (ed.) The Fauna and Stratigraphy of Paleozoic of Baltic and Byelorussia. Mintis, Vilnius. [in Russian with English summary]

Gutiérrez-Marco, J.C., SÁ, A.A., García-Bellido, D.C. \& RÁbano, I. 2017. The Bohemo-Iberian regional chronostratigraphical scale for the Ordovician System and palaeontological correlations within South Gondwana. Lethaia 50(2), 258-295.

DOI 10.1111/let.12197

Hammer, Ø., Harper, D.A.T. \& Ryan, P.D. 2001. PAST: Paleontological Statistics Software Package for Education and Data Analysis. Palaeontologia Electronica 4(1), 1-9.

Harlton, B.H. 1933. Micropaleontology of the Pennsylvanian Johns Valley shale of the Ouachita Mountains, Oklahoma, and its relationship to the Mississippian Caney shale. Journal of Paleontology 7(1), 3-29.

HAVLíčEK, V. 1981. Development of a linear sedimentary depression exemplified by the Prague Basin (Ordovician-Middle Devonian; Barrandian area - central Bohemia). Sborník geologických věd, Geologie 35, 7-48.

HAvlíčEK, V. 1982. Ordovician in Bohemia: development of the Prague Basin and its benthic communities. Sbornik geologických věd, Geologie 37, 103-136.

HavlíčEK, V. 1989. Climatic changes and development of benthic communities through the Mediterranean Ordovician. Sbornik geologických věd, Geologie 44, 79-116.

HavlíčEK, V. 1998. Ordovician, 41-79. In ChlupÁč, I., HavlíčEK, V., Kříž, J., Kukal, Z. \& Štorch, P. (eds) Palaeozoic of the Barrandian (Cambrian to Devonian). Czech Geological Survey, Prague.

HavlíčeK, V. \& Marek, L. 1973. Bohemian Ordovician and its international correlation. Časopis pro mineralogii a geologii 18(3), 225-232.

Havlíček, V. \& Mergl, M. 1982. Deep water shelly fauna in the latest Kralodvorian (upper Ordovician, Bohemia). Věstník Ústředního ústavu geologického 57(1), 37-46.

HAVlíčEK, V. \& VANĚK, J. 1966. The Biostratigraphy of the Ordovician of Bohemia. Sborník geologických véd, Paleontologie 8, 7-69.

HaVlíČEK, V., VANĚK, J. \& FATKA, O. 1994. Perunica microcontinent in the Ordovician (its position within the Mediterranean Province, series division, benthic and pelagic associations). Sborník geologických věd, Geologie 46, 23-56. 
Henningsmoen, G. 1948. The Tretaspis Series of the Kullatorp Core. Bulletin of the Geological Institute of the University of Uppsala 32, 374-432.

Henningsmoen, G. 1953. Classification of Palaeozoic straighthinged ostracods. Norsk Geologisk Tidsskrift 31,185-288.

Henningsmoen, G. 1954. Upper Ordovician ostracods from the Oslo Region, Norway. Norsk Geologisk Tidsskrift 33(1-2), 69-108.

Herrmann, A.D., Haupt, B.J., Patzkowsky, M.E., Seidov, D. \& Slingerland, R.L. 2004. Response of Late Ordovician paleoceanography to changes in sea level, continental drift, and atmospheric $p \mathrm{CO}_{2}$ : potential causes for long-term cooling and glaciation. Palaeogeography, Palaeoclimatology, Palaeoecology 210(2), 385-401. DOI 10.1016/j.palaeo.2004.02.034

Hessland, I. 1949. Lower Ordovician ostracodes of the Siljan District. Bulletin of the Geological Institutions of Uppsala 33, 97-408.

Hughes, D.D. 1954. Barrande's Ostracode Localities. The Micropaleontologist 8(3), 41-47. DOI 10.2307/1483983

JAANUSSON, V. 1957. Middle Ordovician ostracodes of central and southern Sweden. Bulletin of the Geological Institutions of the University of Uppsala 37, 173-442.

Jones, C.R. 1986-1987. Ordovician (Llandeilo and Caradoc) Beyrichiocope Ostracoda from England and Wales. Monograph of the Palaeontological Society. Part 1, 1-76 (Publ. No. 569, part of vol. 138 for 1984). Part 2, 77-114 (Publ. No. 571, part of vol. 139 for 1985).

Jones, P.J. 1968. Upper Devonian Ostracoda and Eridostraca from the Bonaparte Gulf Basin, northwestern Australia. Bureau of Mineral Resources, Geology and Geophysics, Bulletin 99, $1-109$.

Jones, T.R. 1855. Notes on Palaeozoic bivalve Entomostraca. No.1. Some species of Beyrichia from the Upper Silurian Limestones of Scandinavia. Annals and Magazine of Natural History, $2^{\text {nd }}$ Series 16(92), 81-92.

JonES, T.R. 1873. Notes on the Palaeozoic bivalved Entomostraca, no. X. Entomis and Entomidella. Annals and Magazine of Natural History, $4^{\text {th }}$ Series 11(66), 413-417.

Jones, T.R. in Chapman, F. 1901. On some fossils of Wenlock age from Mulde, near Klinteberg, Gotland. Annals and Magazine of Natural History, $7^{\text {th }}$ Series 7(38), 141-160, 146-147, and a table by T.R. JONES.

Jones, T.R. \& Holl, H.B. 1869. Notes on the Palaeozoic Bivalved Entomostraca. No. IX. Some Silurian Species. Annals and Magazine of Natural History, $4^{\text {th }}$ Series 3(15), 211-229.

KAY, G.M. 1940. Ordovician Mohawkian Ostracoda, lower Trenton Decorah fauna. Journal of Paleontology 14(3), 234-269.

Keenan, J.E. 1951. Ostracodes from the Maquoketa shale of Missouri. Journal of Paleontology 25(5), 561-574.

KRAFT, J.C. 1962. Morphologic and systematic relationships of some Middle Ordovician Ostracoda. Geological Society of America Memoir 86, 1-104. DOI 10.1130/MEM86-p1

Kraft, P., Štorch, P. \& Mitchell, C.E. 2015. Graptolites of the
Králův Dvůr Formation (mid Katian to earliest Hirnantian, Czech Republic). Bulletin of Geosciences 90(1), 195-225. DOI 10.3140/bull.geosci.1435

Krause, 1889. Über Beyrichien und verwandte Ostracoden in untersilurischen Geschieben. Zeitschrift der Deutschen Geologischen Gesellschaft 41, 1-26.

KRU゚TA, M. 1968. Orechina n.g. (Ostracoda, Crustacea) from the Upper Ordovician of Bohemia. Časopis pro mineralogii a geologii 13(1), 55-62.

LAtreille, P.A. 1802. Histoire naturelle, générale et particulière, des crustacés et des insectes. Volume 5. 468 pp. F. Dufart, Paris.

Levinson, S.A. 1951. Thin sections of Paleozoic Ostracoda and their bearing on taxonomy and morphology: Journal of Paleontology 25(5), 553-560.

Lindström, M. 1953. On the Lower Chasmops Beds in the Fågelsång District (Scania). Geologiska Föreningens i Stockholm Förhandlingar 75(2), 125-148.

DOI 10.1080/11035895309454168

Lipold, M.V. \& KREJČí, J. 1860. Sitzung am 24. April 1860. Verhandlungen der kaiserlich-königlichen geologischen Reichsanstalt 11, 88-91.

MeidLA, T. 1993. The ostracode genus Longiscula Neckaja, 1958 in the Ordovician of the East Baltic. Neues Jahrbuch für Geologie und Paläontologie, Abhandlungen 188(3), 289-303.

Meidla, T. 1996. Late Ordovician Ostracodes of Estonia. Fossilia Baltica 2. 222 pp. Tartu University Press, Tartu.

MeIdLA, T. 2007. Ostracods from the Upper Ordovician Borenshult fauna, Sweden. GFF 129, 123-132.

DOI 10.1080/11035890701292123

Meidla, T., Ainsaar, L. \& Truuver, K. 2011. Ostracods in Baltoscandia through the Hirnantian crises, 353-357. In Gutiérrez-Marco, J.C., RÁBAno, I. \& Garcia-Bellido, D. (eds) Ordovician of the World. Cuadernos del Museo Geominero 14.

Meidla, T., Tinn, O., Salas, M.J., Williams, M., Siveter, D.J., Vandenbroucke, T.R.A. \& Sabbe, K. 2013. Biogeographical patterns of Ordovician ostracods, 337-354. In HARPER, D.A.T. \& Servais, T. (eds) Early Palaeozoic Biogeography and Palaeogeography. Geological Society London, Memoirs 38.

Meidla, T., Tinn, O., Williams, M. \& Ainsaar, L. 2009. Latest Ordovician ostracod assemblages and biogeography, 47-49. In Suttner, T.J., Hubmann, B. \& Piller, W.E. (eds) Paleozoic Seas Symposium. Graz, 14-18 September 2009, Abstract Volume, Berichte des Institutes für Erdwissenschaften, Karl-FranzensUniversität Graz 14.

Melchin, M.J., Mitchell, C.E., Holmden, C. \& Štorch, P. 2013. Environmental changes in the Late Ordovician - early Silurian: Review and new insights from black shales and nitrogen isotopes. The Geological Society of America Bulletin 125(11/12), 1635-1670. DOI 10.1130/B30812.1

Mergl, M. 2011a. Earliest occurrence of the Hirnantia Fauna in the Prague Basin (Czech Republic). Bulletin of Geosciences 86(1), 63-70. DOI 10.3140/bull.geosci.1245

Mergl, M. 2011b. Faunal turnover near the Katian/Hirnantian boundary in the Prague Basin (Czech Republic), 359-366. In 
Gutiérrez-Marco, J.C., RÁBAno, I. \& García-Bellido, D. (eds) Ordovician of the World. Cuadernos del Museo Geominero 14. 679 pp. Instituto Geológico y Minero de España, Madrid.

Mergl, M. \& VohradsKÝ, O. 2000. Vycházky za geologickými zajímavostmi Plzně a okolí. 270 pp. KOURA publishing, Mariánské Lázně.

Mitchell, C.E., Štorch, P., Holmden, C., Melchin, M.J. \& GutiÉrReZ-Marco, J.C. 2011. New stable isotope data and fossils from the Hirnantian Stage in Bohemia and Spain: implications for correlation and paleoclimate, 371-378. In GUTIÉRREZ-MARCO, J.C., RÁbano, I. \& García-Bellido, D. (eds) Ordovician of the World. Cuadernos del Museo Geominero 14. 679 pp. Instituto Geológico y Minero de España, Madrid.

NeCKAJA, A.I. 1952. New ostracode species from the Ordovician strata of the northwestern part of the Russian Platform. Trudy Vsesoyuznogo neftyanogo nauchno-issledovatel'skogo geologorazvedochnogo instituta (VNIGRI) 60, 217-232. [in Russian]

NeckajA, A.I. 1958. New species and genera of ostracodes of the Ordovician and Silurian of the Russian Platform. Trudy Vsesoyuznogo neftyanogo nauchno-issledovatel'skogo geologorazvedochnogo instituta (VNIGRI) 115, 349-373. [in Russian]

NeCKaja, A.I. 1966. Ostracods of the Ordovician and Silurian of the USSR [families Schmidtellidae, Rectellidae, Longisculidae and some new species of other families]. 104 pp. Nedra, Leningrad. [in Russian]

NõlvaK, J., Meidla, T. \& Hints, L. 1989. The Taucionys Formation (Holorhynchus Beds) in the Iljinskoje boring (Pskov District). Proceedings of the Academy of Sciences of the Estonian SSR, Geology 38(2), 88-93.

Olempska, E. 1994. Ostracods of the Mójcza Limestone, 129-212. In DzIK, J., OlempsKa, E. \& Pisera, A. (eds) Ordovician Carbonate Platform Ecosystem of the Holy Cross Mountains, Poland. Palaeontologia Polonica 53.

OlempSKa E., 2012. Morphology and affinities of Eridostracina: Palaeozoic ostracods with moult retention. Hydrobiologia 688 , 139-165. DOI 10.1007/s10750-011-0659-7

ÖPIK, 1937. Ostracoda from the Ordovician Uhaku and Kukruse formations of Estonia. Publications of the Geological Institutions of the University of Tartu 43, 1-70.

Pereira, S., Marques da Silva, C., Pires, M. \& SÁ, A.A. 2015. The oldest brachymetopid trilobite record from the European peri-Gondwana. Bulletin of Geosciences 90(3), 543-553. DOI 10.3140/bull.geosci.1535

PoKorný, V. 1954. A contribution to the taxonomy of the Paleozoic ostracods. Sbornik Ústředního ústavu geologického, oddil paleontologický 20 (for 1953), 213-232.

PřIBYL, A. 1950. Př́ispěvek k poznání českých ostrakodů z čeledí Entomozoidae a Entomoconchidae. Rozpravy České akademie věd a umění, Třída II 59 (for 1949), 9, 1-27.

PřIBYL, A. 1979. Ostrakoden der Šárka - bis Králův DvůrSchichtengruppe des böhmischen Ordoviziums. Sbornik Národního Muzea, Řada B 33 (for 1977), 53-145.
PřIBYL, A. 1988. Ostracodes from the Silurian of central Bohemia. Sborník geologických Věd, Paleontologie 29, 49-143.

Röhlich, P. \& ChLupÁč, I. 1952. Svrchní ordovik v býv. Reiserově cihelně u Řeporyj. Sborník Ústředního ústavu geologického, oddíl geologický 19, 1-17.

Salas, M.J. \& VAcCari, N.E. 2012. New insights into the early diversification of the Ostracoda: Tremadocian ostracods from the Cordillera Oriental, Argentina. Acta Palaeontologica Polonica 57(1), 175-190. DOI 10.4202/app.2009.1110

Saravia, P.D. \& Jones, P.J. 1999. New Carboniferous (Namurian) glaciomarine ostracods from Patagonia, Argentina. Journal of Micropalaeontology 18, 97-109. DOI 10.1144/jm.18.2.97

SARs, G.O. 1866. Oversigt af Norges marine Ostracoder. Forhandlinger i Videnskabs-Selskabet i Christiania 1865(1), $1-130$.

SARV, L. 1956. New ostracod species of the Vasalemma Stage (Upper Ordovician of Estonia). Trudy Instituta geologii AN ESSR 1, 30-40. [in Russian]

SARV, L. 1959. Ordovician ostracods in the Estonian S.S.R. Trudy Instituta geologii AN ESSR 4, 1-210. [in Russian]

Sarv, L. \& MeIdla, T. 1984. Ostracod distribution pattern in the Ordovician-Silurian boundary beds of the North East Baltic. 22 pp. Akademia nauk Estonskoy SSR, Institut geologii, Tallin (VINITI). [in Russian]

Schallreuter, R. 1967. Zur Taxonomic und Phylogenie der Ostrakodenfamilie Tvaerenellidae Jaanusson, 1957 (Palaeocopina, Hollinacea). Geologie 16(8), 928-943.

Schallreuter, R. 1968. Zur Taxonomie und Phylogenie der Eridostraca (Ostracoda). Paläontologische Zeitschrift 42(1/2), 105-119. DOI 10.1007/BF02987131

SCHALlReuter, R. 1969. Untergattungen der Ostrakodengattung Platybolbina. Geologie 18(7), 877-879.

Schallreuter, R. 1972. Drepanellacea (Ostracoda, Beyrichicopida) aus mittelordovizischen Backsteinkalkgeschieben IV. Laterophores hystrix sp. n., Pedomphalella germanica sp. n. und Easchmidtella fragosa (Neckaja). Berichte der Deutschen Gesellschaft für Geologische Wissenschaften, A Geologie und Paläontologie, 17(1), 139-145.

SchallReuter, R. 1973. Die Ostracodengattung Hyperchilarina und das Aparchites-Problem. Geologiska Föreningens i Stockholm Förhandlingar, 95(1), 37-49. DOI 10.1080/11035897309455423

Schallreuter, R. 1975. Ostrakoden aus Öjlemyrgeschieben (Ordoviz) II. Neues Jahrbuch für Geologie und Paläontologie, Abhandlungen 150(3), 270-293.

Schallreuter, R. 1977. Zwei neue ordovizische Podocopida (Ostracoda) und Bemerkungen zur Herkunft der Cytheracea und Cypridacea. Neues Jahrbuch für Geologie und Paläontologie, Monatshefte 1977(12), 720-734.

Schallreuter, R. 1980. Ostrakoden aus dem Sularpschiefer (Mittelordoviz) von Schonen (Schweden). Palaeontographica A 169(1/3), 1-27.

SCHALlReUter, R. 1981. Ordovician ostracodes from Baltoscandia. Geologiska Föreningens i Stockholm Förhandlingar 103(1), 61-71. DOI 10.1080/11035898109455206 
SCHALlReUter, R. 1984. Geschiebe-Ostrakoden I. Neues Jahrbuch für Geologie und Paläontologie, Abhandlungen 169(1), 1-40.

SCHALlREUTER, R. 1986. Ostrakoden aus Öjlemyrflint-Geschieben von Sylt, 203-232. In НАснт, U. von (ed.) Fossilien von Sylt 2. Verlag und Verlagsbuchhandlung Inge-Maria von Hacht, Hamburg.

SCHALlReuter, R. 1987. Geschiebe-Ostrakoden II. Neues Jahrbuch für Geologie und Paläontologie, Abhandlungen 174(1), 23-53.

Schallreuter, R. 1990a. Ordovizische Ostrakoden und Seeigel der Kamischen Alpen und ihre Beziehungen zu Böhmen und Baltoskandien. Neues Jahrbuch für Geologie und Paläontologie, Monatshefte 1990(2), 120-128.

SCHALlReuter, R. 1990b. Ostrakoden aus Öjlemyrflint-Geschieben von Sylt (2), 251-253. In Hacht, U. vON (ed.) Fossilien von Sylt 3. Verlag und Verlagsbuchhandlung Inge-Maria von Hacht, Hamburg.

Schallreuter, R. 1999. Ordovizische Ostrakoden Hesslands. Archiv für Geschiebekunde 2(9), 673-682.

Schallreuter, R. \& Hinz-Schallreuter, I. 1998. Ein Geschiebe aus Armorica im Thüringer Lederschiefer. Archiv für Geschiebekunde 2(5), 323-360.

Schallreuter, R. \& Hinz-Schallreuter, I. 2010. Sexual dimorphism and pore systems in Ordovician ostracodes. Acta Palaeontologica Polonica 55(4), 741-760.

DOI 10.4202/app.2009.0056

Schallreuter, R. \& HinZ-Schallreuter, I. 2011. New Ostracodes from the Öjlemyr Chert (Late Ordovician) of Gotland and Northern Germany. Bollettino della Societa Paleontologica Italiana 50(3), 209-228

Schallreuter, R. \& KrŮta, M. 1984. On Platybolbina runica sp. nov. Schallreuter and Krůta. A Stereo-Atlas of Ostracod Shells 11(2), 123-126.

Schallreuter, R. \& KRŮTA, M. 1987. The Ordovician ostracode genus Orechina from Bohemia and its Baltic representatives. Neues Jahrbuch für Geologie und Paläontologie, Monatshefte 1987(1), 57-64.

SchallReuter, R. \& KRŮTA, M. 1988. Ordovician Ostracodes of Bohemia. Mitteilungen aus dem Geologisch-Paläontologischen Institut der Universität Hamburg 67, 99-119.

SCHALlReUter, R. \& KRŮTA, M. 1990. On Scanipisthia rectangularis (Troedsson). A Stereo-Atlas of Ostracod Shells 17(2), 89-92.

Schallreuter, R. \& Krůta M. 2001a. Ostracodes from the Dobrotivá Formation (Ordovician, Bohemia). Acta Musei Nationalis Pragae, Series B - Historia Naturalis 56, 95-103.

SCHALlReUter, R. \& KRŮTA, M. 2001b. Ostracodes from the Letná Formation (Ordovician) of the Blýskava Hill (Bohemia). Acta Musei Nationalis Pragae, Series B - Historia Naturalis 56 (2000) (3-4), 85-94.

Schallreuter, R. \& Siveter, D.J. 1985. Ostracodes across the Iapetus Ocean. Palaeontology 28(3), 577-598.

Schmid, E.A. 1941. Studien in böhmischen Caradoc (ZahoranStufe). 1. Ostrakoden aus Bohdalec-Schichten und über die Taxonomie der Beyrichiacea. Abhandlungen der Senckenbergischen Naturforschenden Gesellschaft 454, 1-96.
SchÖNLAUB, H.P. 1985. Exkursion "Wolayer See", 53-69. In Schönlaub, H.P. (ed.) Arbeitstagung der Geologischen Bundesanstalt 1985. Geologische Bundesanstalt, Wien.

Schönlaub, H.P. 1988. The Ordovician-Silurian boundary in the Carnic Alps of Austria, 107-115. In Cocks, L.R.M. \& Rickards, R.B. (eds) A Global Analysis of the OrdovicianSilurian Boundary, Bulletin of the British Museum (Natural History), Geology 43.

Shaver, R.H. 1961. Family Bairdiocyprididae Shaver, n. fam., 364-365. In Moore, R.C. (ed.) Treatise on Invertebrate Paleontology, Part Q. Arthropoda 3, Crustacea, Ostracoda. University of Kansas Press, Lawrence, Kansas.

Shaw, F.C. 2000. Trilobites of the Králův Dvůr Formation (Ordovician) of the Prague Basin, Czech Republic. Bulletin of the Czech Geological Survey 75(4), 371-404.

SidaravičIEnE, N. 1975. New Ordovician ostracoda of South Baltic area, 21-43. In Grigelis, A.A. (ed.) The Fauna and Stratigraphy of Paleozoic and Mesozoic of Baltic and Byelorussia. Mintis, Vilnius. [in Russian with English summary]

SidARAVIČIENE, N. 1992. Ordovician ostracods of Lithuania. 252 pp. Litovskiy nauchnoissledovatelskiy geologorazvedochniy institut (LitNIIGRI), Vilnius.

Siveter, D.J. 2009. The Ordovician, 45-90. In Whittaker, J.E. \& Hart, M.B. (eds) Ostracods in British Stratigraphy. Micropalaeontological Society London, Special Publications 3.

Siveter, D.J. \& Vannier, J.M.C. 1990: The Silurian myodocope ostracode Entomozoe from the Pentland Hills, Scotland; its taxonomic, ecological and phylogenetic significance and the affinity of the bolbozoid myodocopes. Transactions of the Royal Society of Edinburgh, Earth Sciences 81(1), 45-67. DOI 10.1017/S0263593300005125

Skogsberg, T. 1920. Studies on marine ostracods. Part 1. (Cypridinids, Halocyprids and Polycopids). Zoologiska bidrag från Uppsala, Supplement 1, 1-784.

SPIVEY, R.C. 1939. Ostracodes from the Maquoketa shale, Upper Ordovician of Iowa. Journal of Paleontology 13(2), 163-175.

SpJeldnaes, J. 1961. Ordovician climatic zones. Norsk Geologisk Tidsskift 41, 45-77.

ŠTorch, P. \& Mergl, M. 1989. Králodvor/Kosov boundary and the late Ordovician environmental changes in the Prague Basin (Barrandian area, Bohemia). Sborník geologických věd, Geologie 44, 117-153.

ŠTorch, P., ČERnÝ, J., BohátKa, J. \& Melichar, R. 2009. Excavation of the Prague by-pass highway tunnel driven between Radotín and Lochkov - results of geological and palaeontological research. Český kras 35, 5-13.

Šuf, J. \& PrantL, F. 1946. Př́íspěvek k poznání geologické stavby území mezi Berounem a Prahou. Věstník Státního geologického ústavu Československé republiky 21(1-2), 42-69.

SwaIn, F.M. 1987. Middle and Upper Ordovician Ostracoda of Minnesota and Iowa, 99-101. In Sloan, R.E. (ed.) Middle and Late Ordovician Lithostratigraphy and Biostratigraphy of the Upper Mississippi Valley, Minnesota Geological Survey, Report of Investigations 35. 
SWARTZ, 1936. Revision of the Primitiidae and Beyrichiidae with new Ostracoda from the Lower Devonian of Pennsylvania. Journal of Paleontology 10, 541-586.

Sylvester-Bradley, P.C. 1961. Suborder Metacopina, SylvesterBradley, n. suborder, 358-359. In Moore, R.C. (ed.) Treatise on Invertebrate Paleontology, Part Q. Arthropoda 3, Crustacea, Ostracoda. University of Kansas Press, Lawrence, Kansas.

Sztejn, J. 1985. Małżoraczki ordowiku w Północno-wschodniej Polsce. Biuletyn Instytutu Geologicznego 350, 53-89.

Troedsson, G.T. 1918. Om Skanes Brachiopodskiffer. Acta Universitatis Lundensis, Sectio 2 15(3), 1-104.

Truuver, K. \& Meidla, T. 2015. A Hirnantian deep-water refuge for warm-water ostracods in Baltoscandia. Geological Quarterly 59(4), 738-749. DOI 10.7306/gq.1258

Truuver, K., Meidla, T., Ainsaar, L., Bergström, J. \& Tinn, O. 2012. Stratigraphy of the Ordovician-Silurian boundary interval in Östergötland, Sweden, based on ostracod distribution and stable carbon isotopic data. GFF 134, 295-308.

DOI 10.1080/11035897.2012.762550

Ulrich, E.O. 1879. Descriptions of new genera and species of fossils from the Lower Silurian about Cincinnati. The Journal of the Cincinnati Society of Natural History 2, 8-30.

ULrich, E.O. 1890-1891. New and little known American Paleozoic Ostracoda. The Journal of the Cincinnati Society of Natural History 13, 104-137, 173-211.

Ulrich, E.O. 1894. Lower Silurian Ostracoda of Minnesota. Final Report of the Geological and Natural History Survey of Minnesota 3, 629-693.

Ulrich, E.O. \& BAssLer, R.S. 1906. New American Paleozoic Ostracoda. Notes and descriptions of Upper Carboniferous genera and species. United States Natural Museum, Proceedings 30, 149-164.

Ulrich, E.O. \& BAssler, R.S. 1923. Paleozoic ostracoda: their morphology, classification and occurrence. Maryland Geological Survey, Silurian 9, 271-391.

Ulst, R.Z., Gailīte, L.K. \& Yakovleva, V.I. 1982. The Ordovician of Latvia. 294 pp. Zinatne, Riga. [in Russian]

Vandenbroucke, T.R.A., Armstrong, H.A., Williams, M., Paris, F., Zalasiewicz, J.A., Sabbe, K., Nõlvak, J., Challands, T.J., Verniers, J. \& Servais, T. 2010. Polar front shift and atmo- spheric $\mathrm{CO}_{2}$ during the glacial maximum of the Early Paleozoic Icehouse. Proceedings of the National Academy of Sciences 107(34), 14983-14986.

DOI 10.1073/pnas.1003220107

VAnNier, J.M.C. \& ABe, K. 1992. Recent and early Palaeozoic myodocope ostracodes: functional morphology, phylogeny, distribution and lifestyles. Palaeontology 35(3), 485-517.

Vannier, J.M.C., Siveter, D.J. \& Schallreuter, R.E.L. 1989. The composition and palaeogeographical significance of the Ordovician ostracode faunas of southern Britain, Baltoscandia, and Ibero-Armorica. Palaeontology 32(1), 163-222.

Vecoli, M. \& Hérissé, A. Le 2004. Biostratigraphy, taxonomic diversity and patterns of morphological evolution of Ordovician acritarchs (organic-walled microphytoplankton) from the northern Gondwana margin in relation to palaeoclimatic and palaeogeographic changes. Earth-Science Reviews 67, 267-311. DOI 10.1016/j.earscirev.2004.03.002

Warshauer, S.M. \& BERDAN, J.M. 1982. Palaeocopid and podocopid Ostracoda from the Lexington Limestone and Clays Ferry Formation (Middle and Upper Ordovician) of Central Kentucky, 1-80. In Pojeta, J. JR. (ed.) Contributions to the Ordovician Paleontology of Kentucky and nearby states, Geological Survey Professional Paper 1066- $\mathrm{H}$.

Webby, B.D. 2002. Patterns of Ordovician reef development, 129-179. In Kiessling, W., Flügel, E. \& GolonKa, J. (eds) Phanerozoic Reef Patterns. Society for Sedimentary Geology Special Publication 72. DOI 10.2110/pec.02.72.0129

Williams, M. \& VAnnieR, J.M.C. 1995. Middle Ordovician Aparchitidae and Schmidtellidae: the significance of 'featureless' ostracods. Journal of Micropalaeontology 14, 7-24.

DOI 10.1144/jm.14.1.7

Williams, M., Floyd, J.D., Salas, M., Siveter, D.J., Stone, P. \& VANNIER, J.M.C. 2003. Patterns of ostracod migration for the 'North Atlantic' region during the Ordovician. Palaeogeography, Palaeoclimatology, Palaeoecology 195, 193-228. DOI 10.1016/S0031-0182(03)00308-0

Williams, M., Stone, P., Siveter, D.J. \& TaYlor, P. 2001. Upper Ordovician ostracods from the Cautley District, northern England: Baltic and Laurentian affinities. Geological Magazine 138, 589-607. DOI 10.1017/S0016756801005726 